Monitoring Completed Navigation Projects Program

Periodic Inspection of St. Paul Harbor Breakwater, Alaska

Robert R. Bottin, Jr., and Alan C. Jeffries 
The contents of this report are not to be used for advertising, publication, or promotional purposes. Citation of trade names does not constitute an official endorsement or approval of the use of such commercial products.

The findings of this report are not to be construed as an official Department of the Army position, unless so designated by other authorized documents. 


\section{Periodic Inspection of St. Paul Harbor Breakwater, Alaska}

by Robert R. Bottin, Jr.

Coastal and Hydraulics Laboratory

U.S. Army Engineer Research and Development Center 3909 Halls Ferry Road

Vicksburg, MS 39180-6199

Alan C. Jeffries

U.S. Army Engineer District, Alaska

P.O. Box 898

Anchorage, AK 99506-0898

Final report

Approved for public release; distribution is unlimited 


\section{Contents}

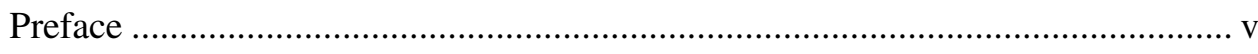

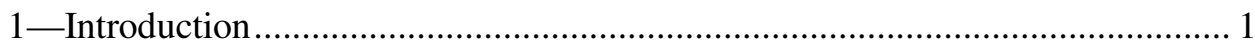

Monitoring Completed Navigation Projects Program...................................... 1

Work Unit Objective and Monitoring Approach ............................................. 2

Project Location and History ...................................................................... 3

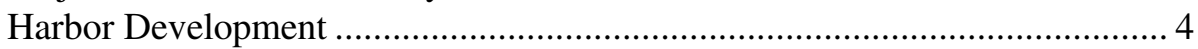

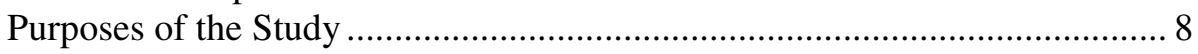

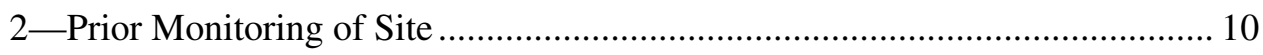

Comprehensive MCNP Monitoring....................................................... 10

Armor Layer Monitoring ……............................................................ 10

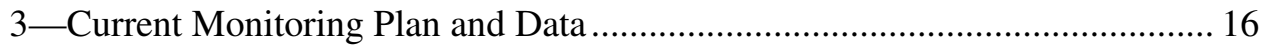

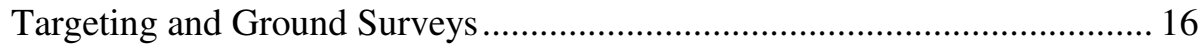

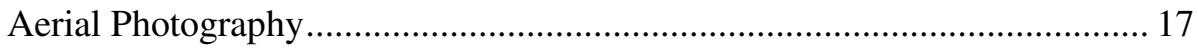

Photogrammetric Analysis of Armor Units ............................................. 17

Broken Armor Stone Survey...................................................................... 27

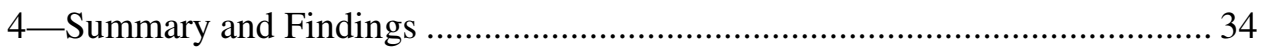

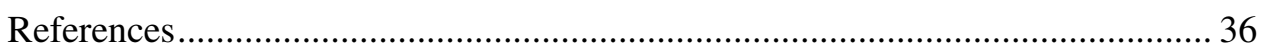

Appendix A: Breakwater Topography, 2000 .............................................. A1

Appendix B: Breakwater Cross Sections, 1994, 1996, and 2000......................B1

\section{List of Figures}

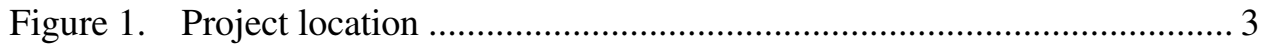

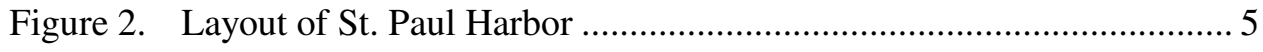

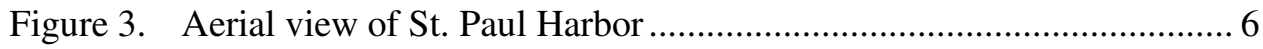


Figure 4. Typical breakwater cross sections .................................................. 7

Figure 5. Layout of submerged reef breakwaters........................................... 9

Figure 6. Example of a target established on breakwater ............................. 17

Figure 7. Locations of monuments/targets established on breakwater.............. 18

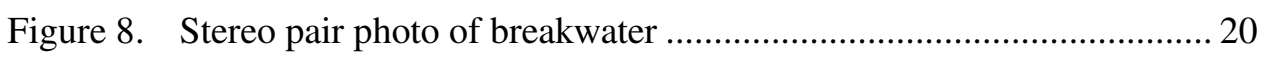

Figure 9. Orthophoto for a portion of St. Paul breakwater ............................. 23

Figure 10. Point plot map for a portion of St. Paul breakwater .......................... 25

Figure 11. Example of difference contours for breakwater between 1996

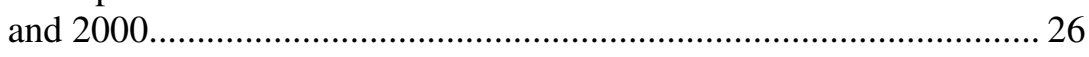

Figure 12. View of broken armor stone on St. Paul Harbor breakwater

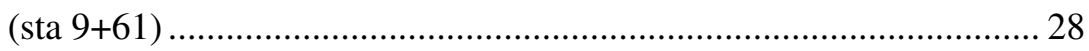

Figure 13. View of broken armor stone on St. Paul Harbor breakwater

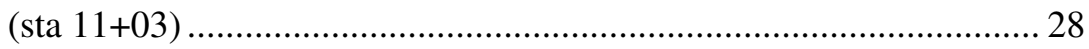

Figure 14. View of broken armor stone on St. Paul Harbor breakwater

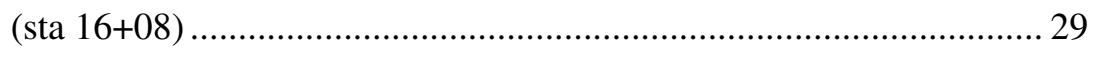

Figure 15. View of broken armor stone on St. Paul Harbor breakwater

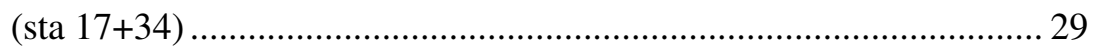

Figure 16. Distribution of broken armor stones along breakwater trunk

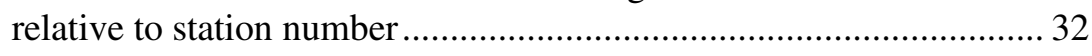

Figure 17. Distribution of broken armor stones relative to distance from baseline 


\section{Preface}

The study reported herein was conducted as part of the Monitoring Completed Navigation Projects (MCNP) Program, formerly Monitoring Completed Coastal Projects Program. Work was conducted under Work Unit IM-7, "Periodic Inspections." Overall program management for MCNP is administrated by Headquarters, U.S. Army Corps of Engineers (HQUSACE). The Coastal and Hydraulics Laboratory (CHL), U.S. Army Engineer Research and Development Center (ERDC), is responsible for technical as well as data management and support for HQUSACE review and technology transfer. Program Monitors for the MCNP program are Messrs. Barry W. Holliday, Charles B. Chesnutt, and David B. Wingerd (HQUSACE). The Program Manager is Mr. Robert R. Bottin, Jr., CHL.

This report is part of a series which tracks the long-term structural response of the St. Paul Harbor, AK, breakwater to its environment. Limited ground surveys, aerial photography, and photogrammetric analysis of the breakwater were conducted by Richard B. Davis, Inc., Smith River, CA, under contract to the Corps of Engineers, and a broken armor unit survey was completed by Messrs. Bottin, Hugh F. Acuff, Larry R. Tolliver, and Tim Conrad (ERDC) and Mr. Alan C. Jeffries, U.S. Army Engineer District, Alaska (CEPOA).

The work was conducted during the period June through August 2000 under the general supervision of Messrs. Thomas W. Richardson and Thomas J. Pokrefke, Jr., Acting Director and Acting Assistant Director, respectively, CHL, and under direct supervision of Mr. Dennis G. Markle, Chief, Harbors and Entrances Branch. This report was prepared by Messrs. Bottin and Jeffries.

At the time of publication of this report, Dr. James R. Houston was Director of ERDC, and COL James S. Weller, EN, was Commander.

The contents of this report are not to be used for advertising, publication, or promotional purposes. Citation of trade names does not constitute an official endorsement or approval of the use of such commercial products. 


\section{Conversion Factors, Non-SI to SI Units of Measurement}

Non-SI units of measure used in figures, plates, and tables of this report can be converted to SI units as follows:

\begin{tabular}{||l|l|l||}
\hline Multiply & By & To Obtain \\
\hline \hline acres & $4,046.856$ & square meters \\
\hline cubic yards & 0.7646 & cubic meters \\
\hline degrees (angle) & 0.01745329 & radians \\
\hline feet & 0.3048 & meters \\
\hline inches & 2.54 & centimeters \\
\hline miles (U.S. statute) & 1.609347 & kilometers \\
\hline pounds (mass) & 0.4535924 & kilograms \\
\hline tons (2,000 pounds, mass) & 907.1847 & kilograms \\
\hline \hline
\end{tabular}




\section{Introduction}

\section{Monitoring Completed Navigation Projects Program}

The goal of the Monitoring Completed Navigation Projects (MCNP) Program (formerly the Monitoring Completed Coastal Projects Program) is the advancement of coastal and hydraulic engineering technology. The program is designed to determine how well projects are accomplishing their purposes and are resisting attacks by their physical environment. These determinations, combined with concepts and understanding already available, will lead to creating more accurate and economical engineering solutions to coastal and hydraulic problems; to strengthening and improving design criteria and methodology; to improving construction practices and cost-effectiveness; and to improving operation and maintenance techniques. Additionally, the monitoring program will identify where current technology is inadequate or where additional research is required.

To develop direction for the program, the U.S. Army Corps of Engineers initially established an ad hoc committee of engineers and scientists. The committee formulated the objectives of the program, developed its operation philosophy, recommended funding levels, and established criteria and procedures for project selection. A significant result of their efforts was a prioritized listing of problem areas to be addressed, essentially a listing of the areas of interest of the program.

Corps offices are invited to nominate projects for inclusion in the monitoring program as funds become available. A selection committee, comprised of members of the MCNP Program Field Review Group (representatives from District and Division offices), reviews and prioritizes the projects nominated. The prioritized list is reviewed by the Program Monitors at Headquarters, U.S. Army Corps of Engineers (HQUSACE). Final selection is based on this prioritized list, national priorities, and the availability of funding.

The overall monitoring program is under the management of the Coastal and Hydraulics Laboratory (CHL), U.S. Army Engineer Research and Development Center (ERDC), with guidance from HQUSACE. An individual monitoring project is a cooperative effort between the submitting District/Division office and CHL. Development of monitoring plans and the conduct of data collection and 
analyses are dependent upon the combined resources of CHL and the District/Division. The inspection for the study reported herein, was completed as part of the "Periodic Inspections" work unit of the MCNP program.

\section{Work Unit Objective and Monitoring Approach}

The objective of the "Periodic Inspections" work unit in the MCNP program is to monitor selected coastal navigation structures periodically to gain an understanding of the long-term structural response of unique structures to their environment. These periodic data sets are used to improve knowledge in design, construction, and maintenance of both existing and proposed coastal navigation projects. These data also will help avoid repeating past design mistakes that have resulted in structure failure and/or high maintenance costs. Past projects monitored under the MCNP program and/or structures with unique design features that may have application at other sites are considered for inclusion in the periodic inspections monitoring program. Selected sites are presented as candidates for development of a periodic monitoring plan. Once the monitoring plan for a site is approved and funds are provided, monitoring of the site is initiated. Normally, base conditions are established and documented in the initial effort. The site then is reinspected periodically (frequency of surveys is based on a balance of need and funding for each monitoring site) to obtain long-term structural performance data.

Relatively low-cost remote sensing tools and techniques, with limited ground truthing surveys, are the primary inspection tools used in the monitoring efforts. Most periodic inspections consist of capturing above water conditions of the structure at periodic intervals using high resolution aerial photography. Periodic aerial photographs are compared visually to gauge the degree of in-depth analysis required to quantify structural changes (primarily armor unit movement). Data analysis involves using photogrammetric techniques developed for and successfully applied at other coastal sites. At sites where local wave data are being gathered by other projects and/or agencies, and these data can be acquired at a relatively low cost, wave data are correlated with structural changes. In areas where these data are not available, general observations and/or documentation of major storms occurring in the locality are presented along with the monitoring data. Ground surveys are limited to the level needed to establish accuracy of the photogrammetric techniques.

When a coastal structure is photographed at low tide, an accurate permanent record of all visible armor units is obtained. Through the use of stereoscopic, photogrammetric instruments in conjunction with photographs, details of structural geometry can be defined at a point in time. By direct comparison of photographs taken at different times, as well as the photogrammetric data resolved from each set of photographs, geometric changes (i.e., armor unit movement and/or breakage) of the structure can be defined as a function of time. Thus, periodic inspections of the structures will capture permanent data that can be compared and analyzed to determine if structure changes are occurring that indicate possible failure modes and the need to monitor the structure(s) more closely. The St. Paul Harbor, AK, breakwater was nominated for periodic 
monitoring by the U.S. Army Engineer Division (USAED), Pacific Ocean (CEPOD).

\section{Project Location and History}

St. Paul Island is the northernmost and largest island of the Pribilofs in the eastern Bering Sea (Figure 1) with a land area of $114 \mathrm{sq} \mathrm{km} \mathrm{(44} \mathrm{sq} \mathrm{mi).}{ }^{1}$ The Pribilofs are of volcanic origin, and St. Paul is composed predominantly of volcanic materials in the form of lava flows and loose cinders with sandy deposits. The west and southwest portions of the island are relatively high and mountainous with precipitous cliffs along the coast. The remainder of the island is relatively low and rolling with a number of extinct volcanic peaks scattered throughout. Only two of the Pribilof Islands are populated, St. Paul with 800 people and St. George with 290 people. Two-thirds of the St. Paul population is Alaskan native.

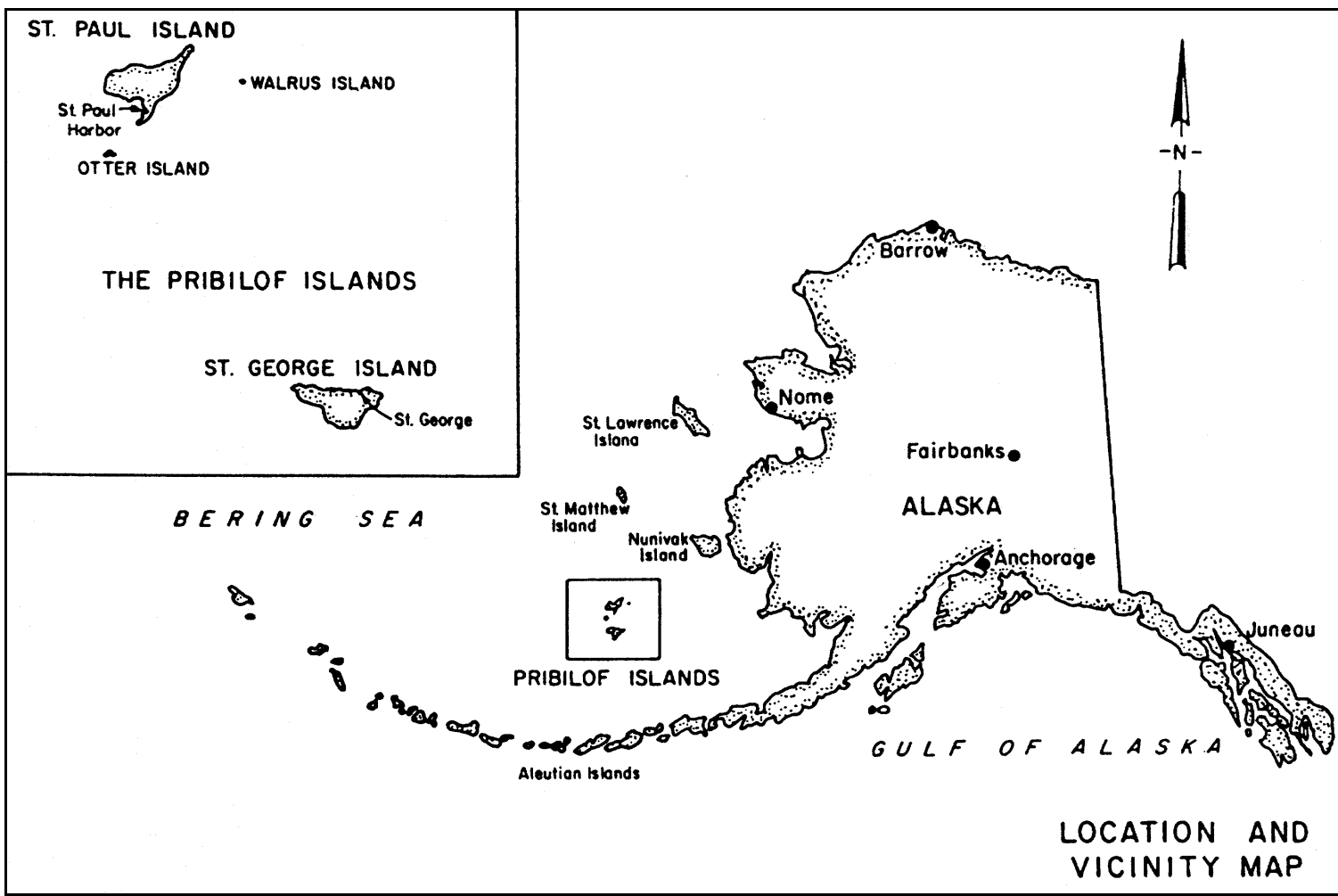

Figure 1. Project location

The Pribilof Islands support large populations of birds, mammals, fish, and invertebrates. The Pribilofs are the primary breeding ground for northern fur seals where approximately two-thirds of the world's population (1.3 to

${ }^{1}$ Units of measurement in the text of this report are shown in SI (metric) units, followed by non-SI (British) units in parenthesis. In addition, a table of factors for converting non-SI units of measurement used in figures in this report to SI units is presented on page vi. 
1.4 million) migrate annually (U.S. Army Engineer District (USAED), Alaska, 1981). More than a quarter million seabirds nest on St. Paul Island each year, mainly along the coastal cliffs. The uplands are inhabited by songbirds, white and blue foxes, and a transplanted herd of approximately 250 reindeer. The island is treeless and covered with grasses, sedges, and wildflowers. The eastern Bering Sea near St. Paul supports populations of shrimp, commercially harvestable species of crab, and bottom fish.

The city of St. Paul is located on a cove on the southern tip of the island and is the island's only settlement. The islands were originally settled by the Russians to harvest fur seals. The treaty for the purchase of Alaska from Russia by the United States in 1867 placed the Pribilofs under United States control. The National Marine Fisheries Service (NMFS) and its predecessor Federal agencies were responsible for the fur seal industry in the Pribilofs since 1911, managing the harvest according to a series of international agreements between the United States, Canada, Japan, and the Soviet Union. In 1983, the harvest of fur seals was discontinued due to a seal harvest moratorium. The NMFS terminated administration, management, and employment at St. Paul. This event had a significant adverse impact on the economy, and the standard of living could not be maintained. At that time the village had no other economic base, no harbor infrastructure, inadequate and unpermitted utilities, overcrowded housing, high unemployment, and limited air and vessel transportation. Development of a harbor, and associated marine related industries, fulfilled the need for new sources of employment and income on the island.

\section{Harbor Development}

A breakwater was constructed at St. Paul in Village Cove in 1984, but subsequently failed during storms in that year. A new breakwater was designed and constructed by Tetra Tech, Inc., consultants to the city of St. Paul (Tetra Tech, Inc. 1987). The structure was $229 \mathrm{~m}(750 \mathrm{ft})$ in length and functioned well, with regard to stability, during the 1985 and 1986 winter seasons. A 61-mlong (200-ft-long), vertical-wall dock was subsequently installed in the lee of the breakwater in 1986 to accommodate fishing vessels. The breakwater, however, was not of sufficient length to provide wave protection to vessels using the dock, particularly during storm events.

In 1989, construction of the current harbor configuration was completed. A layout of the harbor is shown in Figure 2. It consisted of a 549-m-long (1,800-ftlong) main breakwater, a 296-m-long (970-ft-long) detached breakwater, and $274 \mathrm{~m}(900 \mathrm{ft})$ of dock space on the lee side of the main breakwater. The main breakwater, generally, follows the $-7.6-\mathrm{m}(-25-\mathrm{ft})^{1}$ contour in Village Cove and results in a harbor with 32,375 to 40,470 sq $\mathrm{m}$ ( 8 to 10 acres) of area and water depths of 5.5 to $7.6 \mathrm{~m}$ ( 18 to $25 \mathrm{ft}$ ) on the lee side of the breakwater. The center line of the detached breakwater makes an interior angle of $75 \mathrm{deg}$ with the main

\footnotetext{
${ }^{1}$ All contours and elevations cited herein are in meters (feet) referred to mean lower low water (mllw) unless otherwise noted.
} 


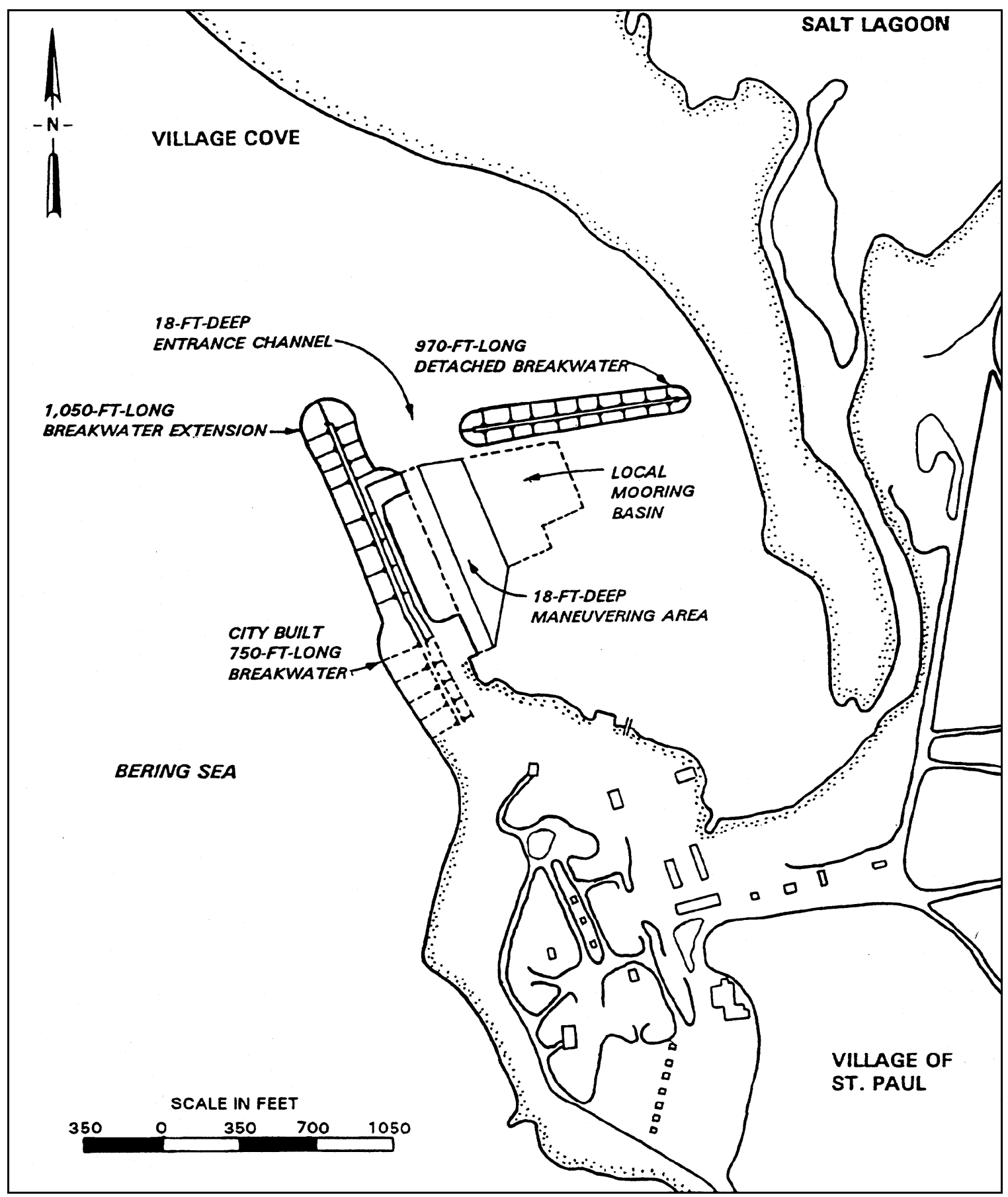

Figure 2. Layout of St. Paul Harbor (To convert feet to meters, multiply by 0.3048 )

structure at sta $17+00$, and provides a 91 -m-wide (300-ft-wide) harbor entrance. A 61-m-wide (200-ft-wide) opening between the eastern end of the detached breakwater and the shore is maintained to enhance harbor circulation. An aerial photograph of the existing St. Paul Harbor is shown in Figure 3. 


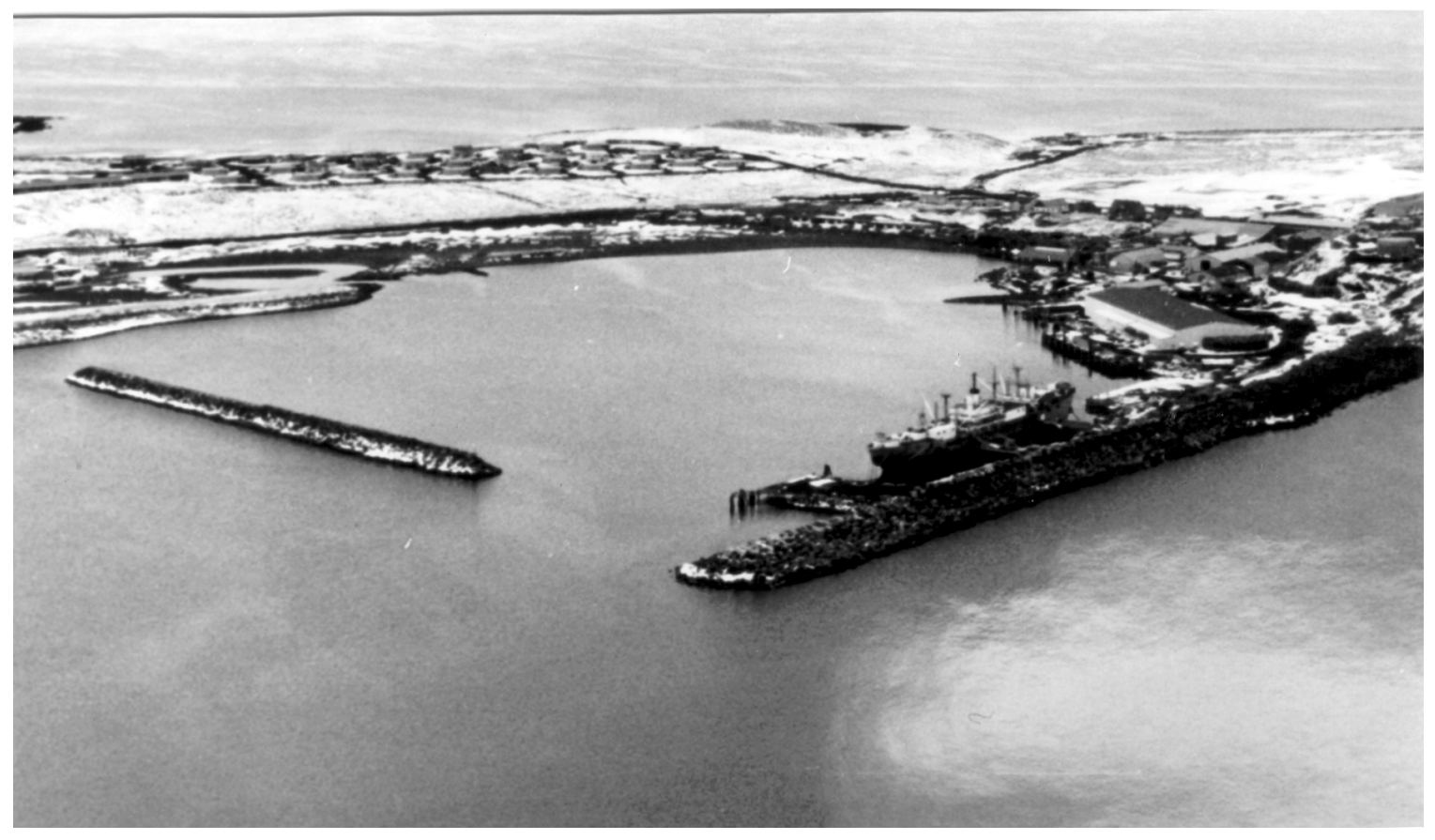

Figure 3. Aerial view of St. Paul Harbor

The main breakwater has a design crest elevation (el) of $+11.3 \mathrm{~m}(+37 \mathrm{ft})$ from sta $7+50$ to a point approximately $15.2 \mathrm{~m}(50 \mathrm{ft})$ north of the northernmost dock. The remaining portion of the structure has a design crest el of $+9.1 \mathrm{~m}$ $(+30 \mathrm{ft})$. Armor stone used on the breakwater trunk was $16,330 \mathrm{~kg}$ (18-ton), and 21,770-kg (24-ton) armor stone was used on the head. Special placement of the armor stone was specified in the contract documents which required orientation of the long axis of each stone normal to the breakwater slope. The slope of the trunk is $1 \mathrm{~V}: 2 \mathrm{H}$ with a $1 \mathrm{~V}: 2.5 \mathrm{H}$ slope around the breakwater head. A roadway was constructed on the lee side of the main breakwater adjacent to the proposed docks. The detached breakwater has a design crest el of $+5.5 \mathrm{~m}(+18 \mathrm{ft})$ with 4,535-kg (5-ton) armor stone placed on a slope of $1 \mathrm{~V}: 1.5 \mathrm{H}$. Typical cross sections of the main and detached breakwater trunks are shown in Figure 4. Prior to construction of the 1989 improvements, both two-dimensional (Ward 1988) and three-dimensional (Bottin and Mize 1988) hydraulic model investigations were conducted at ERDC to optimize the structural and functional design of the harbor.

After construction of the harbor in 1989, it experienced a rapid growth cycle and quickly became overcrowded. In the mid 1990s St. Paul Harbor served a fleet of 230 transient vessels during the crabbing season. A total of 27 floating processors were located within a $4.8-\mathrm{km}$ (3-mi) limit of the harbor. In addition, three processing plants had permanently located within the harbor complex. Subsequent to harbor construction, significant overtopping of the main breakwater had been experienced during the winter seasons. Overtopping may have been caused by larger than design storm waves and/or still water levels or possible settlement and consolidation of the breakwater stone. Overtopping 


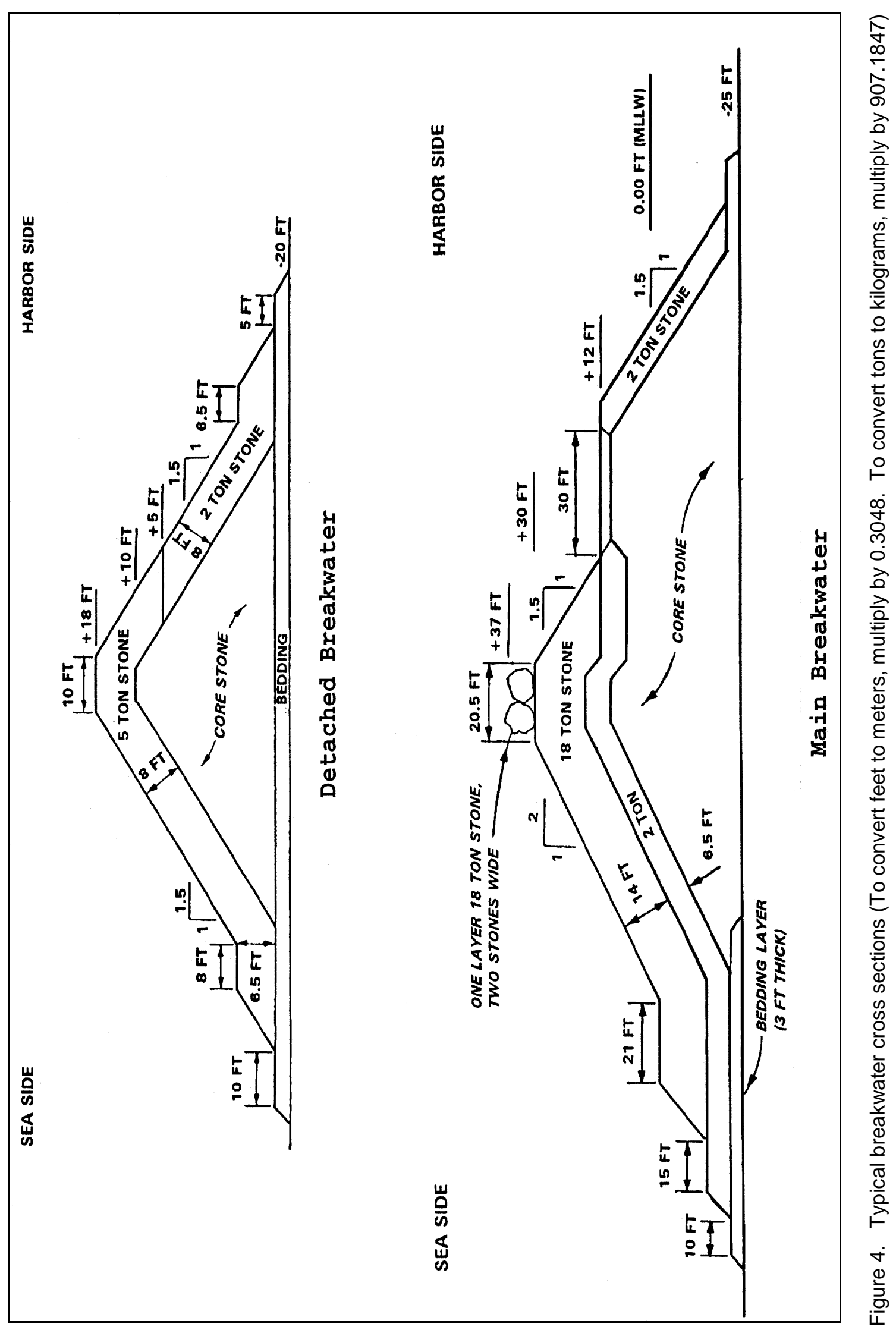


caused the roadway in the lee of the breakwater to wash out, and repairs were required frequently during the storm season. Due to these problems and needs, the harbor was again studied at CHL in 1996. The feasibility of deepening the entrance channel and dredging a deeper and larger maneuvering basin was proposed to relieve congestion in the harbor. In addition, a submerged reef breakwater concept was studied as a means of reducing wave overtopping of and wave transmission through the main breakwater. Two- and three-dimensional model investigations were conducted by Ward (1996) ${ }^{1}$ and Bottin (1996), respectively, to optimize reef breakwater cross sections and layout as well as wave and current conditions in the expanded harbor.

Construction of three parallel, submerged reef breakwaters seaward of the main breakwater was initiated during the 2000 construction season. The reef structures were constructed with 455 - to $3,630-\mathrm{kg}(1,000$ - to $8,000-\mathrm{lb})$ stone at an

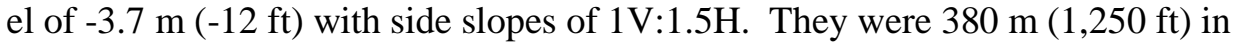
length. The shoreward crest of the innermost reef was $52 \mathrm{~m}(170 \mathrm{ft})$ from the toe of the existing main breakwater. The crest widths of the reefs were $6.1 \mathrm{~m}(20 \mathrm{ft})$, and the crests were $21.3 \mathrm{~m} \mathrm{(70} \mathrm{ft)} \mathrm{apart.} \mathrm{The} \mathrm{reefs} \mathrm{were} \mathrm{placed} \mathrm{on} \mathrm{bedding} \mathrm{stone}$ that ranged from 9 to $225 \mathrm{~kg}$ (20 to $500 \mathrm{lb}$ ). A layout of the reef breakwaters is shown in Figure 5. In addition, the contract included that a total of 25 selected armor stones be placed in voids that had occurred in main breakwater due to displacement as a result of storms. In June 2000 these armor stones were placed on the breakwater along the waterline between stas $8+80$ and $9+70$.

\section{Purposes of the Study}

The purposes of the study reported herein were as follows:

a. To develop methods using limited land-based surveying, aerial photography, and photogrammetric analysis to assess the long-term stability response of the stone armor layer on the St. Paul Harbor main breakwater.

$b$. To conduct limited land surveys, a broken armor stone inspection, aerial photography, and photogrammetric analyses to test and improve developed methodologies and accurately define armor unit movement above the waterline.

c. To re-examine data obtained in previous monitoring efforts and determine and define changes that have occurred to the stone armor layer.

$d$. To establish new baseline data since construction of the reef breakwaters seaward of the existing St. Paul Harbor main breakwater. Subsequent monitoring will determine the effectiveness of these new reef breakwater structures relative to damage at the existing breakwater.

${ }^{1}$ Ward, D. L. (1996). "Runup and overtopping studies for St. Paul Harbor breakwater, St. Paul Alaska," (unpublished). U.S. Army Engineer Waterways Experiment Station, Vicksburg, MS. 


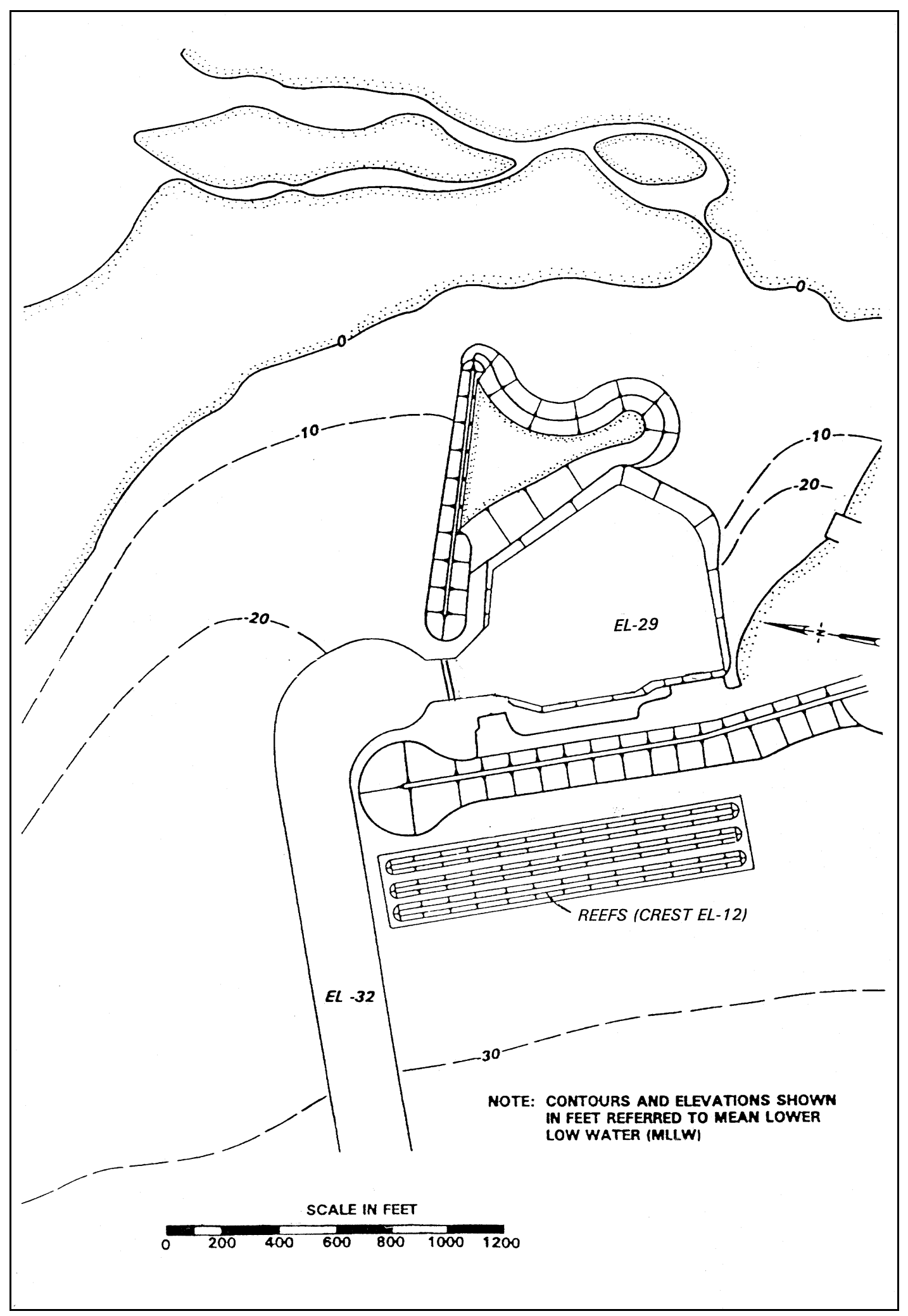

Figure 5. Layout of submerged reef breakwaters (To convert feet to meters, multiply by 0.3048) 


\section{Prior Monitoring of Site}

\section{Comprehensive MCNP Monitoring}

The St. Paul Harbor project was initially selected for monitoring under the MCNP program in 1992. The primary objective of the monitoring effort was to determine if the harbor and its structures were performing (both functionally and structurally) as predicted by the model studies used for project design. Wave, current, and bathymetry measurements at the project site would determine the effectiveness of the functional design aspects. Ground-based surveys and photogrammetric flights of the main breakwater would reveal its structural response to the wave environment. Run-up and overtopping rates would be secured and compared to values obtained in the two-dimensional model study and values computed from guidance provided in the Shore Protection Manual (1984). These unique prototype measurements would aid in refining the design predictions of run-up and overtopping, which in turn would aid in future economic, structurally sound, and functional breakwater designs.

Data collection for the monitoring program at St. Paul Harbor occurred from July 1993 through June 1996. Elements of the monitoring program included a wave hindcast study and data collection of waves (both inside and outside the harbor), currents inside the harbor, water levels, bathymetry in and adjacent to the harbor, wave run-up heights on the breakwater, wave overtopping rates, and ground and photogrammetric surveys of the main breakwater, as well as surveys of armor stone quality. Results of this study were published in Bottin and Eisses (1997). Aerial photography, photogrammetric analysis of above-water armor stone, and broken armor unit survey data obtained, which are relative to armor layer monitoring in the Periodic Inspections work unit, are summarized in more detail in the following section.

\section{Armor Layer Monitoring}

\section{Aerial photography}

Aerial photography is an effective means of capturing images of large areas for later analysis, study, visual comparison to previous or subsequent photography, or measurement and mapping. Its chief attribute is the ability to 
freeze a moment in time while capturing great detail. Low altitude aerial photography was obtained along the outer $320-\mathrm{m}(1,050-\mathrm{ft})$ length of the main breakwater with a Wild RC-8 aerial mapping camera (22.9-cm by 22.9-cm (9-in by 9 -in) format). These photos were secured from a helicopter flying at an

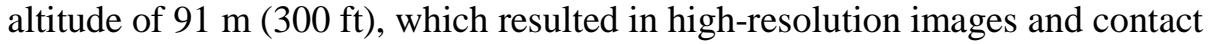
prints at a scale of 1:600. Photographic stereo pairs were obtained during the flights. The photography was obtained during May 1994 and May 1996.

Prior to obtaining aerial photography, limited ground surveys were conducted and targets were established on breakwater. Targets were established using electronic land surveying techniques from geodetic and vertical control benchmarks and were visible in the aerial photography. They were located along the sea side, harbor side, and approximate center line of the breakwater at various intervals along the structure.

\section{Photogrammetric analysis of armor layer}

When aerial photography is planned and conducted to allow each photo image to overlap the next by 60 percent or more, the two photographs comprising the overlap area can be positioned under an instrument called a stereoscope and viewed in extremely sharp three-dimensional detail. If properly selected survey points on the ground have previously been targeted and are visible in the overlapping photography, very accurate three-dimensional measurements of any point appearing in the photographs can be obtained. This technique is called photogrammetry. The low-altitude stereo pair images obtained during aerial photography at St. Paul Harbor were viewed in a stereoscope, and stereomodels were oriented to the monument data and the target data previously obtained. In the stereomodel, accurate horizontal and vertical measurements can be made of any point on any armor stone appearing in the print. The stereomodel was used for all photogrammetric compilation and development of orthophotography.

Orthophotos combine the image characteristics of a photograph with the geometric qualities of a map. The digital orthophoto is created by scanning an aerial photograph with a precision imagine scanner. The scanned data file is digitally rectified to an orthographic projection by processing each image pixel. Orthophotos were prepared for the outer 320-m (1,050-ft) length of the St. Paul Harbor main breakwater. Precise horizontal measurements may be obtained from the orthophotos using an engineer scale since the image has been rectified and is free from skewness and distortion.

In addition to digital orthophotos, point plot maps, contour maps, and cross sections were developed for the main breakwater using the digital terrain model (DTM). Point plot maps consisted of an approximately $0.5-\mathrm{m}(1.5-\mathrm{ft})$ grid pattern overlaid on the structure. Precise vertical and horizontal measurements were obtained at the intersections of the grid. Contour maps of the breakwater, developed from the DTM, for a 0.3-m (1-ft) contour interval also were obtained. In addition, using the analytical stereoplotter and DTM grid, cross sections of the breakwater were developed along the structure at 30.5-m (100-ft) intervals. 
An examination of breakwater topography obtained in May 1996 revealed low areas along much of the breakwater. Only about five percent of the higher portion of the structure (sta $7+50-15+10$ ) was at its design el of $+11.3 \mathrm{~m}$ $(+37 \mathrm{ft})$, and nine percent of the lower portion of the breakwater (sta $15+10$ $18+00)$ was at its design el of $+9.1 \mathrm{~m}(+30 \mathrm{ft})$. For the higher portion of the structure, the el of about 24 percent of the length of the breakwater was within $0.3 \mathrm{~m}(1.0 \mathrm{ft})$ of its design el, or between +11.0 and $+11.3 \mathrm{~m}(+36 \mathrm{and}+37 \mathrm{ft})$; and approximately 66 percent of the structure was between +10.7 and $+11.3 \mathrm{~m}$ $(+35$ and $+37 \mathrm{ft})$, or within $0.61 \mathrm{~m}(2 \mathrm{ft})$ of its design el. About 29 percent of the structure length was below $+10.7 \mathrm{~m}(+35 \mathrm{ft})$. Most of the low area (that below $+10.7 \mathrm{~m}(+35 \mathrm{ft}))$ appeared to be concentrated between stas $13+70$ and $15+10$. For the lower portion of the structure, the el of about 50 percent of the length of the breakwater was within $0.3 \mathrm{~m}(1.0 \mathrm{ft})$ of its design el, or between +8.8 and $+9.1 \mathrm{~m} \mathrm{(+29}$ and $+30 \mathrm{ft})$; and approximately 89 percent of the structure was within $0.61 \mathrm{~m}(2.0 \mathrm{ft})$ of its design el, or between +8.5 and $+9.1 \mathrm{~m}(+28$ and $+30 \mathrm{ft})$. Only two percent of the structure length was below $+8.5 \mathrm{~m}(+28 \mathrm{ft})$.

Contours showing the differences in elevation of the St. Paul Harbor breakwater extension from May 1994 to May 1996 revealed very slight change. Results indicated essentially no change along the crown of the structure. In the vicinity of sta $9+50$, an elevation change of up to $0.9 \mathrm{~m}(3 \mathrm{ft})$ occurred along the waterline on the sea side of the structure. Other elevation changes (between 0.3 and $0.9 \mathrm{~m}$ ( 1 and $3 \mathrm{ft})$ ) generally occurred on the harbor side of the breakwater. Data generally indicated no settlement of the structure crown between 1994 and 1996.

Examination of cross section data revealed that cross sections of the breakwater were similar in both 1994 and 1996. Accretion of stone along the toe of the harbor side slope of the structure was apparent at stas $11+00,12+00$, and $13+00$. This was an accumulation of small stones which was noted during a site visit in 1996. It is not known if this was core stone moving out of the breakwater due to wave action or loose stone moving over and/or through the voids of the structure during storms.

In summary, the photogrammetric surveys of the St. Paul Harbor breakwater extension were very effective in accurately mapping the above-water portion of the structure and showing changes in el occurring between 1994 to 1996. Results indicated that low areas existed along the length of the breakwater. Only 5 percent of the breakwater length (adjacent to the roadway) was at, or above, its design el, and almost a third was at least $0.61 \mathrm{~m}(2 \mathrm{ft})$ below its design el. This could contribute to the undesirable overtopping of the breakwater that had been experienced. The main breakwater extension may have subsided after initial construction causing the lower than design elevations. However, essentially no change in el occurred between 1994 and 1996 based on results of the photogrammetric analysis. 


\section{Broken armor stone surveys}

A survey of broken/cracked armor stone above the waterline on the 320-mlong (1,050-ft-long) St. Paul Harbor outer main breakwater was conducted four times during the original monitoring period. Surveys were conducted in July 1993, June 1994, June 1995, and June 1996. During the inspections, each broken armor stone was identified and photographed, and its approximate location relative to breakwater station and distance from a baseline was recorded. The baseline was the approximate center line of the structure. Armor stones with hairline cracks were not counted; only those that were cracked all the way through were counted. A geological assessment of the broken stone was conducted during the June 1995 survey.

The armor stone survey of the main breakwater during July 1993 revealed a total of 73 broken or cracked armor stones above the waterline. Of the 73 stones, seven stones were located on the crest, 31 on the seaward slope, and 35 on the harbor side slope. In the vicinity of the northernmost dock at sta 14+30 (the seaward end of the $+11.3-\mathrm{m}$ ( $+37-\mathrm{ft}$ ) el portion of the breakwater), some void areas between adjacent capstones were noted. The capstones had migrated apart away from each other.

The June 1994 survey yielded a total of 131 broken or cracked armor stones. Of these 131 units, 24 were located on the crest, 59 on the seaward slope, and 48 on the harbor side slope. Observations during this inspection revealed that the separated capstones identified in 1993 (sta 14+30) were in approximately the same position.

During the broken/cracked armor unit survey of June 1995, a total of 191 broken or cracked armor stones was identified. Of the 191 stones, 35 broken/cracked armor stones were located on the crest, 93 on the seaward slope, and 63 on the harbor side slope. Several broken stones documented during previous surveys could not be found, indicating they had been moved away by wave and/or ice action. Also, it was observed that stones were missing along the water's edge on the seaward face of the structure at approximately stas $8+85$ and $9+50$. The 1994-95 winter was relatively severe with the presence of much floating ice. The voids at the waterline on the main breakwater were subsequently repaired by the U.S. Army Engineer District, Alaska (CENPA) during the summer of 1995 using selected stones from the St. Paul Island quarry. The repair work was a modification to an existing bank stabilization contract for which the contractor was hauling stone from St. Paul Island. The largest available stone already shot in the quarry $(9,070$ - to $13,610-\mathrm{kg}$ (10- to 15 -ton) was selected for the repair. A total of 13 and eight selected stones were placed in the vicinities of stas 8+85 and 9+50, respectively, in August 1995.

During the 1995 survey, a detailed geologic inspection of the breakwater was conducted by representatives of the U.S. Army Engineer District, Buffalo (CENCB). These personnel had experience in armor stone quality and durability for coastal projects. Based on their analyses, 22 percent of the above-water stones was experiencing advanced degradation. This degradation is attributed to two factors. First, the project contains about 25 percent geologically 
unacceptable stone. The unacceptable stone is a light gray, vesicular banded basalt that has a marked platy structure. This stone likely came from the Smithrock Quarry in Camas, WA. About one-half of this stone contained one or more significant cracks. These cracked stones exhibited common freeze-thaw crack characteristics. The delamination process is being enhanced at the St. Paul location because of the number of cycles of freeze-thaw and wet-dry conditions as well as large waves and sea ice action. Secondly, a significant amount of the stone on the structure was blast damaged. Fracture patterns and shape characteristics observed on much of the stone is common in overshot rock. As observed commonly in other breakwaters, this structure was predicted to continue to deteriorate, and the degradation rate was likely to increase as time progressed at this environmentally harsh location. It was also predicted that future project performance would be significantly impacted in the next 3 to 7 years and needed repairs should be expected.

During the breakwater survey of June 1996, a total of 230 broken/cracked armor stones was identified on the main breakwater. Of the 230 stones, 54 were located on the crest, 105 on the seaward slope, and 71 on the harbor side slope. The rate of breakage was slightly less for this survey than for previous years. However, the harbor master indicated that the 1995-96 winter was milder than normal. Only two broken armor units were noted around the head of the structure. Armor stone for the breakwater head consisted of sound and durable granite from a quarry in Nome, AK. Shoreward of the breakwater head, broken stones were, generally, evenly distributed along the length of the structure.

Forty-nine percent of the broken stones were located on the shoreward half of the breakwater extension, and 51 percent on the outer half. About 23 percent of the observed broken stones were along the crest, 46 percent on the seaward slope, and 31 percent on the harbor side slope. Fifty percent of the broken stones were located on the upper half of the breakwater slopes ( 27 percent on the sea side and 23 percent on the harbor side); and 27 percent were on the lower half of the structure slopes (18 percent on the sea side and 9 percent on the harbor side). It was also noted during the June 1996 survey that the separated capstones at sta $14+30$, initially observed in July 1993, approximately about in the same position. The repair stone placed at stas $8+85$ and $9+50$ in 1995 were also inspected during the summer of 1996. The inspection revealed that three of the original 13 stones in the vicinity of sta $8+85$ and one of the original eight in the vicinity of sta $9+50$ were missing. It is assumed that these stones were dislodged by storm waves and may have been deposited downslope along the toe of the structure below the water surface.

In summary, the broken armor unit surveys of the outer 320-m-long (1,050-ft-long) St. Paul main breakwater conducted during the original monitoring effort revealed progressive armor stone breakage. The number of broken/cracked armor stones on this portion of the structure increased from 73 in July 1993 to 230 in June 1996. A geologic assessment revealed that a significant amount of stone was geologically unacceptable, and also that, a substantial portion of stone on the breakwater was blast-damaged. At the end of the monitoring period, the breakwater was functioning in an acceptable manner, and overall, was in good structural condition. However, degradation of the armor 
stone continued to occur. Continued deterioration was predicted due to freezethaw and wet-dry cycles as well as large waves and sea ice action.

A walking inspection of the main breakwater was conducted by Alaska District personnel in May 1997 subsequent to the comprehensive monitoring effort. At sta 8+85, the repair stone placed in 1995 indicated no changes from the previous year's inspection. All 10 remaining repair stones were noted as being in place. At sta $9+50$, it was noted that an additional stone was missing since the previous inspection. There was a total of six of the originally placed repair stones in place at this area. Waves during the 1996/97 storm season likely dislodged the stone and deposited it on the structure slope below the waterline.

An inspection of the breakwater armor stone in June 1998 by Alaska District personnel indicated that the area at the waterline in the vicinity of stas $8+85$ and $9+50$ had worsened. Several additional stones had been lost since the last inspection. Two to three stones were noted lost from each area, and the structure was scalloped at the waterline. No exposed core stone was noted, however. The harbor master reported that only one significant storm had occurred during the previous year and that wave energy impacts on the breakwater were relatively mild.

An armor unit inspection was again conducted in May 1999 by Alaska District and CHL personnel. It was noted that most the repair stones at both stas $8+85$ and $9+50$ were missing. Only four of the original 13 stones at sta $8+85$ were in place and three of the original eight at sta $9+50$. A large scallop in the sea-side slope was evident, but no core stones were exposed. In addition, armor stone movement along other areas of the structure was observed as well as slight subsidence of the crest in some areas. The separated armor stones at sta $14+30$ at the northermost dock had increased from several inches to several feet since completion of the monitoring effort in 1996 resulting in a significant void. One large capstone on the crest had cracked in two and the seawardmost portion had rolled down the face of the slope. It was noted that more capstones had deteriorated through freeze-thaw cycles through the sedimentary layers. Two additional stones had rolled off the crest down the seaward breakwater slope. Two armor stones on the seaward face of the breakwater had tilted upslope. Several large events occurred during the 1998/99 storm season in the Bering Sea that likely caused the armor stone displacements. 


\section{Current Monitoring Plan and Data}

The objective of the current monitoring effort in the Periodic Inspections work unit was to re-examine the armor stone on the outer 320-m-long (1,050-ftlong) portion of the St. Paul Harbor main breakwater and determine changes that have occurred since the last MCNP-funded inspection in 1996. In addition, new base level data would be established to determine the effectiveness of the new submerged reef breakwaters (currently under construction) upon the long-term stability response of the St. Paul breakwater in future surveys. The monitoring plan consisted of targeting, limited ground surveys, aerial photography, photogrammetric analysis of armor units above the waterline, a broken armor stone survey, and comparisons of breakwater topography and cross sections with those obtained previously.

\section{Targeting and Ground Surveys}

Prior to the photogrammetric survey work for the St. Paul Harbor main breakwater, limited ground surveys were conducted. Existing monuments in the vicinity of the harbor (a National Geodetic Survey station and a Corps of Engineers station) served as reference points (both horizontal and vertical reference) for the ground-based survey work as well as photogrammetric work. Ground surveys were initiated from these monuments. Monuments and targets were also established on the breakwater using global positioning system (GPS) control surveying and electronic land surveying techniques. Monuments consisted of brass disks cemented into place, and targets were painted to ensure visibility in aerial photography. Each target was marked with a drill hole $0.64 \mathrm{~cm}(1 / 4 \mathrm{in})$ in diameter, and $0.64 \mathrm{~cm}$ (1/4 in) deep, to aid in finding its location during subsequent surveys. Targets were established at intervals of about $55 \mathrm{~m}(180 \mathrm{ft})$ along the sea side, harbor side, and approximate center of the breakwater. Targets were used to form control by which the accuracy of the photogrammetric work could be validated. A typical target on the St. Paul breakwater is shown in Figure 6. The locations of monuments/targets established on the breakwater are shown in Figure 7, and their positions and elevations are presented in Table 1 for the May 1996 and June 2000 surveys. Horizontal positions are based on the Alaska State Plane Coordinate System and elevations are referenced to mean lower low water datum. Although slight movement may have occurred between 1996 and 2000, the 1996 control points were used for 


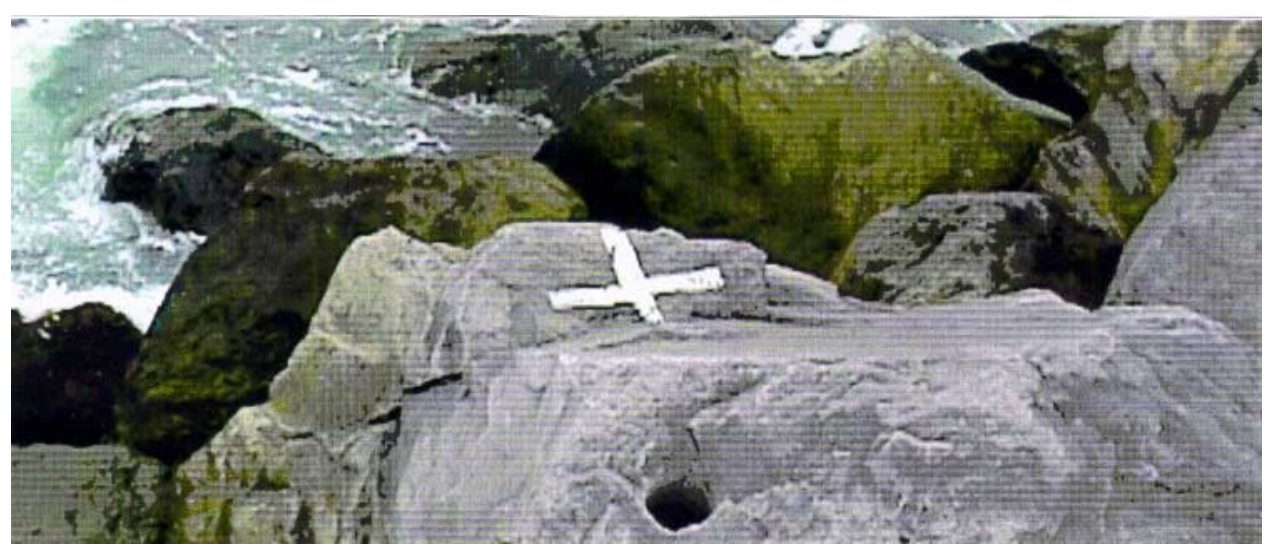

Figure 6. Example of a target established on breakwater

truthing the 1996 photogrammetric flight, and the 2000 control points for the 2000 photogrammetric flight. In some cases, targets were not recovered and were re-established.

\section{Aerial Photography}

Aerial photography was obtained along the breakwater with a Zeiss Jena LMK aerial mapping camera (22.86-cm by $22.86-\mathrm{cm}$ (9-in by 9 -in) format). Photos were secured from a helicopter flying at an altitude of approximately $107 \mathrm{~m}(350 \mathrm{ft})$, which resulted in high resolution images and contact prints with scales of 1:700. Photographic stereo pairs were obtained during the flights run down the center line of the structure. Stereo pairs secured for the breakwater during the flights are shown in Figure 8. The aerial photography was obtained on 2 June 2000.

\section{Photogrammetric Analysis of Armor Units}

The stereo pair images obtained during aerial photography at St. Paul Harbor were viewed in an analytical stereoplotter, and stereomodels were oriented to the monument data previously obtained. In the stereomodel, accurate horizontal and vertical measurements can be made of any point on any armor stone appearing in the print. The accuracy of photogrammetric spot elevations in the stereomodels was on the order of $+/-0.015 \mathrm{~m}(+/-0.05 \mathrm{ft})$. The stereomodel was used for all photogrammetric compilation and development of orthophotography.

Orthophotos were prepared for the outer 320-m-long (1,050-ft-long) main breakwater. Precise horizontal measurements may be obtained from the orthophotos using an engineer scale since the image has been rectified and is free from skewness and distortion. An example of an orthophoto is shown in Figure 9.

In addition to digital orthophotos, point plot maps, contour maps, and cross sections were developed for the outer breakwater in 2000 using a DTM. Point 


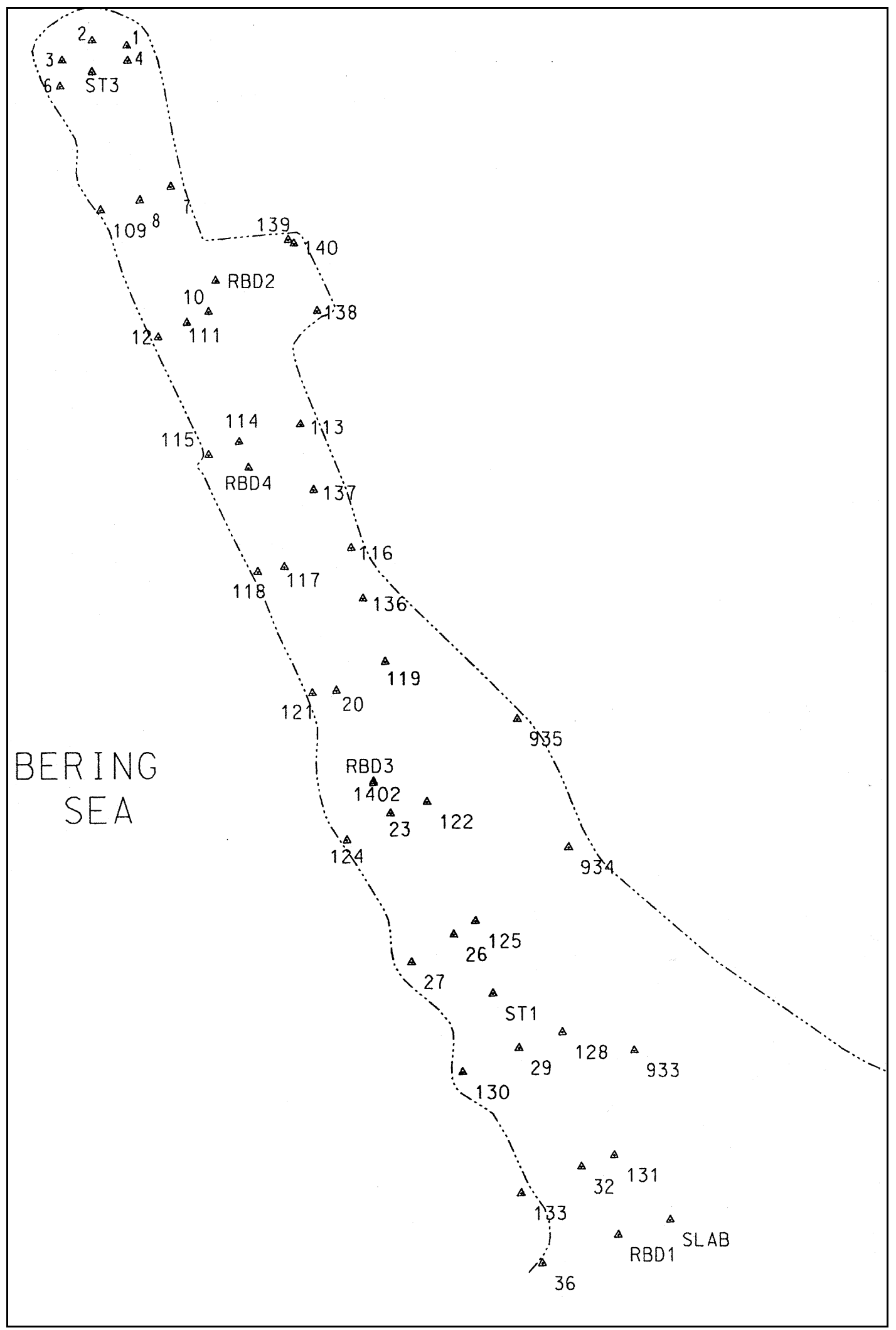

Figure 7. Locations of monuments/targets established on breakwater 


\begin{tabular}{|c|c|c|c|c|c|c|c|}
\hline \multicolumn{4}{|c|}{1996 Coordinates } & \multicolumn{4}{|c|}{2000 Coordinates } \\
\hline $\begin{array}{l}\text { Monument/ } \\
\text { Target }\end{array}$ & Northing & Easting & $\begin{array}{l}\text { Elevation } \\
\mathrm{m}(\mathrm{ft})\end{array}$ & $\begin{array}{l}\text { Monument/ } \\
\text { Target }\end{array}$ & Northing & Easting & $\begin{array}{l}\text { Elevation } \\
\mathrm{m}(\mathrm{ft})\end{array}$ \\
\hline 1 & 1142652.07 & 1583206.18 & $2.947(9.67)$ & 1 & 1142651.96 & 1583206.13 & $\begin{array}{ll}2.938 & (9.64) \\
\end{array}$ \\
\hline 2 & 1142659.59 & 1583160.41 & $4.621(15.16)$ & 2 & 1142659.63 & 1583160.43 & $4.575 \quad(15.01)$ \\
\hline 103 & 1142631.77 & 1583120.79 & $4.535(14.88)$ & 3 & 1142631.93 & 1583120.68 & $\begin{array}{ll}4.459 & (14.63)\end{array}$ \\
\hline 4 & 1142631.19 & 1583206.84 & 4.051 (13.29) & 4 & 1142631.17 & 1583206.87 & $\begin{array}{ll}4.048 & (13.28) \\
\end{array}$ \\
\hline 106 & 1142596.76 & 1583118.79 & $4.188(13.74)$ & 6 & 1142596.18 & 1583118.04 & $\begin{array}{ll}4.020 & (13.19) \\
\end{array}$ \\
\hline 7 & 1142460.51 & 1583263.11 & $2.615(8.58)$ & 7 & 1142460.52 & 1583263.19 & $\begin{array}{ll}2.615 & (8.58) \\
\end{array}$ \\
\hline 8 & 1142442.74 & 1583222.48 & $8.918(29.26)$ & 8 & 1142442.40 & 1583223.01 & $\begin{array}{ll}8.906 & (29.22) \\
\end{array}$ \\
\hline $109 \mathrm{R}$ & 1142431.20 & 1583178.25 & $3.008(9.87)$ & 109 & 1142429.07 & 1583171.22 & $\begin{array}{ll}2.286 & (7.50) \\
\end{array}$ \\
\hline 10 & 1142292.03 & 1583312.49 & $5.758(18.89)$ & 10 & 1142291.95 & 1583312.44 & $\begin{array}{ll}5.742 & (18.84) \\
\end{array}$ \\
\hline 111 & 1142277.39 & 1583284.30 & $10.333(33.90)$ & 111 & 1142277.30 & 1583284.16 & $\begin{array}{ll}10.263 & (33.67)\end{array}$ \\
\hline 12 & 1142258.28 & 1583246.38 & $3.018(9.90)$ & 12 & 1142258.02 & 1583246.30 & $\begin{array}{ll}2.935 & (9.63) \\
\end{array}$ \\
\hline $113 \mathrm{R}$ & 1142137.59 & 1583399.10 & $3.386(11.11)$ & 113 & 1142140.33 & 1583433.00 & $\begin{array}{ll}2.021 & (6.63) \\
\end{array}$ \\
\hline 114 & 1142115.65 & 1583348.21 & $10.817(35.49)$ & 114 & 1142116.94 & 1583352.32 & $\begin{array}{ll}10.769 & (35.33)\end{array}$ \\
\hline $115 \mathrm{R}$ & 1142094.10 & 1583317.15 & $4.206(13.80)$ & 115 & 1142099.41 & 1583311.79 & $4.063(13.33)$ \\
\hline $116 \mathrm{R}$ & 1141953.72 & 1583450.18 & $4.612(15.13)$ & 116 & 1141973.13 & 1583498.58 & $\begin{array}{ll}2.451 & (8.04) \\
\end{array}$ \\
\hline 117 & 1141948.14 & 1583411.18 & $10.836(35.55)$ & 117 & 1141948.05 & 1583411.11 & $10.793 \quad(35.41)$ \\
\hline $118 \mathrm{R}$ & 1141919.53 & 1583375.38 & $2.984(9.79)$ & 118 & 1141941.41 & 1583376.43 & 4.075 (13.37) \\
\hline $119 \mathrm{R}$ & 1141783.75 & 1583541.18 & $3.880(12.73)$ & 119 & 1141819.10 & 1583542.55 & $\begin{array}{ll}3.783 & (12.41) \\
\end{array}$ \\
\hline 20 & 1141780.25 & 1583479.39 & $11.003(36.10)$ & 20 & 1141780.44 & 1583478.74 & $\begin{array}{ll}10.903 & (35.77) \\
\end{array}$ \\
\hline $121 \mathrm{R}$ & 1141768.77 & 1583433.35 & $3.767(12.36)$ & 121 & 1141777.61 & 1583447.18 & $\begin{array}{ll}4.624 & (15.17) \\
\end{array}$ \\
\hline $122 \mathrm{R}$ & 1141630.24 & 1583595.83 & $4.584(15.04)$ & 122 & 1141630.20 & 1583595.81 & $\begin{array}{ll}4.560 & (14.96) \\
\end{array}$ \\
\hline 23 & 1141614.76 & 1583549.07 & $10.851(35.60)$ & 23 & 1141614.66 & 1583549.06 & $\begin{array}{ll}10.848 & (35.59)\end{array}$ \\
\hline 124 & 1141578.41 & 1583491.71 & $2.771(9.09)$ & 124 & 1141578.43 & 1583491.87 & $\begin{array}{ll}2.752 & (9.03)\end{array}$ \\
\hline 125 & 1141468.40 & 1583656.97 & $5.874(19.27)$ & 125 & 1141468.93 & 1583658.25 & $\begin{array}{ll}5.749 & (18.86) \\
\end{array}$ \\
\hline 26 & 1141451.02 & 1583629.91 & 11.424 (37.48) & 26 & 1141450.93 & 1583629.92 & $\begin{array}{ll}11.421 & (37.47) \\
\end{array}$ \\
\hline 27 & 1141413.01 & 1583575.63 & $3.414(11.20)$ & 27 & 1141413.34 & 1583575.42 & $\begin{array}{ll}335 & (10.94) \\
\end{array}$ \\
\hline $128 \mathrm{R}$ & 1141317.83 & 1583772.68 & $5.078(16.66)$ & 128 & 1141317.81 & 1583772.65 & \begin{tabular}{|ll}
5.047 & $(16.56)$ \\
\end{tabular} \\
\hline 29 & 1141296.86 & 1583715.06 & $8.214(26.95)$ & 29 & 1141296.82 & 1583715.05 & $\begin{array}{ll}8.205 & (26.92) \\
\end{array}$ \\
\hline 130 & 1141264.04 & 1583641.16 & $2.334(7.66)$ & 130 & 1141263.95 & 1583641.20 & $\begin{array}{ll}2.310 & (7.58) \\
\end{array}$ \\
\hline 131 & 1141151.34 & 1583841.04 & $8.059(26.44)$ & 131 & 1141151.31 & 1583841.03 & $\begin{array}{ll}8.016 & (26.30) \\
\end{array}$ \\
\hline 32 & 1141136.13 & 1583797.23 & $7.199(23.62)$ & 32 & 1141136.12 & 1583797.25 & $\begin{array}{ll}7.190 & (23.59) \\
\end{array}$ \\
\hline 133 & 1141101.44 & 1583718.77 & $2.670(8.76)$ & 133 & 1141100.38 & 1583717.69 & $\begin{array}{ll}2.822 & (9.26) \\
\end{array}$ \\
\hline 36 & 1141011.01 & 1583751.03 & $2.908(9.54)$ & 36 & 1141005.07 & 1583745.42 & $3.091 \quad(10.14)$ \\
\hline 136 & 1141902.78 & 1583516.36 & $4.173(13.69)$ & 136 & 1141904.84 & 1583513.77 & $\begin{array}{ll}3.648 & (11.97) \\
\end{array}$ \\
\hline $137 \mathrm{R}$ & 1142043.96 & 1583463.74 & 4.167 (13.67) & 137 & 1142051.88 & 1583450.03 & $\begin{array}{ll}3.737 & (12.26) \\
\end{array}$ \\
\hline 138 & 1142293.55 & 1583455.22 & 3.825 (12.55) & 138 & 1142293.52 & 1583455.18 & $\begin{array}{ll}3.755 & (12.32) \\
\end{array}$ \\
\hline 139 & 1142389.02 & 1583417.89 & $3.859(12.66)$ & 139 & 1142389.03 & 1583417.84 & $\begin{array}{ll}3.783 & (12.41) \\
\end{array}$ \\
\hline 933 & 1141285.83 & 1583888.45 & $5.087(16.69)$ & 933 & 1141292.99 & 1583867.86 & $\begin{array}{ll}5.310 & (17.42) \\
\end{array}$ \\
\hline 934 & 1141567.82 & 1583781.67 & $3.523(11.56)$ & 934 & 1141567.75 & 1583781.67 & $3.447 \quad(11.31)$ \\
\hline 935 & 1583713.86 & 1141741.59 & $3.597(11.80)$ & 935 & 1141741.48 & 1583713.78 & $3.520 \quad(11.55)$ \\
\hline RBD1 & 1141043.51 & 1583846.36 & $8.845(29.02)$ & RBD1 & 1141043.51 & 1583846.36 & $\begin{array}{ll}8.845 & (29.02) \\
\end{array}$ \\
\hline RBD2 & 1142333.97 & 1583322.10 & 4.111 (13.49) & RBD2 & 1142333.94 & 1583322.17 & $\begin{array}{ll}4.112 & (13.49) \\
\end{array}$ \\
\hline RBD3 & 1141658.09 & 1583527.06 & $11.433(37.51)$ & RBD3 & 1141657.99 & 1583527.03 & $\begin{array}{ll}11.430 & (37.50) \\
\end{array}$ \\
\hline RBD4 & 1142081.57 & 1583363.79 & $11.070(36.32)$ & RBD4 & 1142081.91 & 1583364.55 & $10.964 \quad(35.97)$ \\
\hline ST1 & 1141370.41 & 1583680.67 & $10.333(33.90)$ & ST1 & 1141370.43 & 1583680.69 & $\begin{array}{ll}10.330 & (33.89) \\
\end{array}$ \\
\hline ST3 & 1142615.80 & 1583159.99 & $8.784(28.82)$ & ST3 & 1142615.83 & 1583160.01 & $\begin{array}{ll}8.757 & (28.73) \\
\end{array}$ \\
\hline & & & & NEW 140 & 1142384.22 & 1583425.40 & $\begin{array}{ll}3.386 & (11.11) \\
\end{array}$ \\
\hline & & & & NEW 1402 & 1141655.75 & 1583527.09 & $\begin{array}{ll}11.305 \quad(37.09) \\
\end{array}$ \\
\hline & & & & SLAB & 1141063.61 & 1583915.29 & $\begin{array}{ll}7.705 & (25.28)\end{array}$ \\
\hline
\end{tabular}



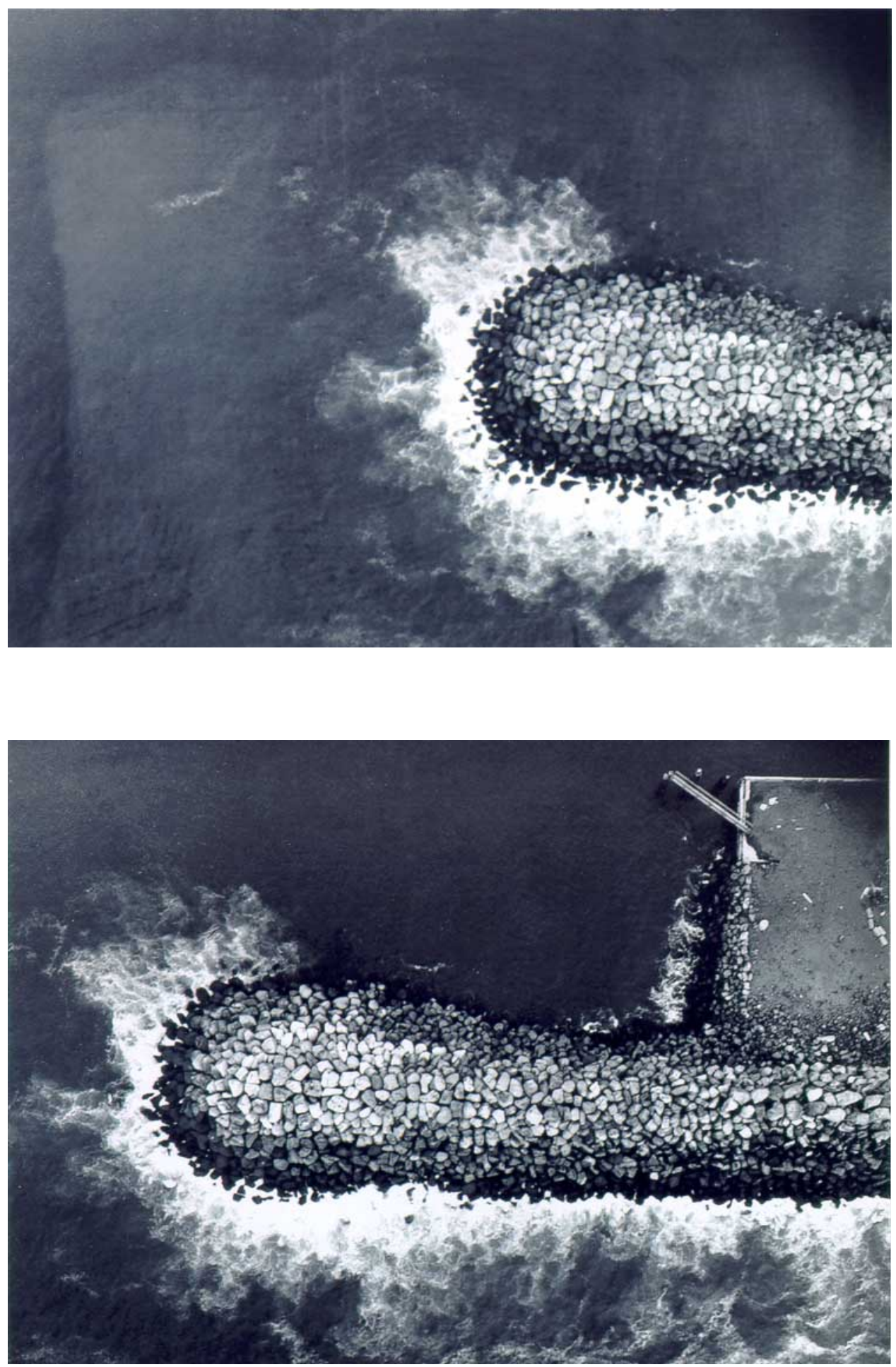

Figure 8. Stereo pair photo of breakwater (Sheet 1 of 3) 

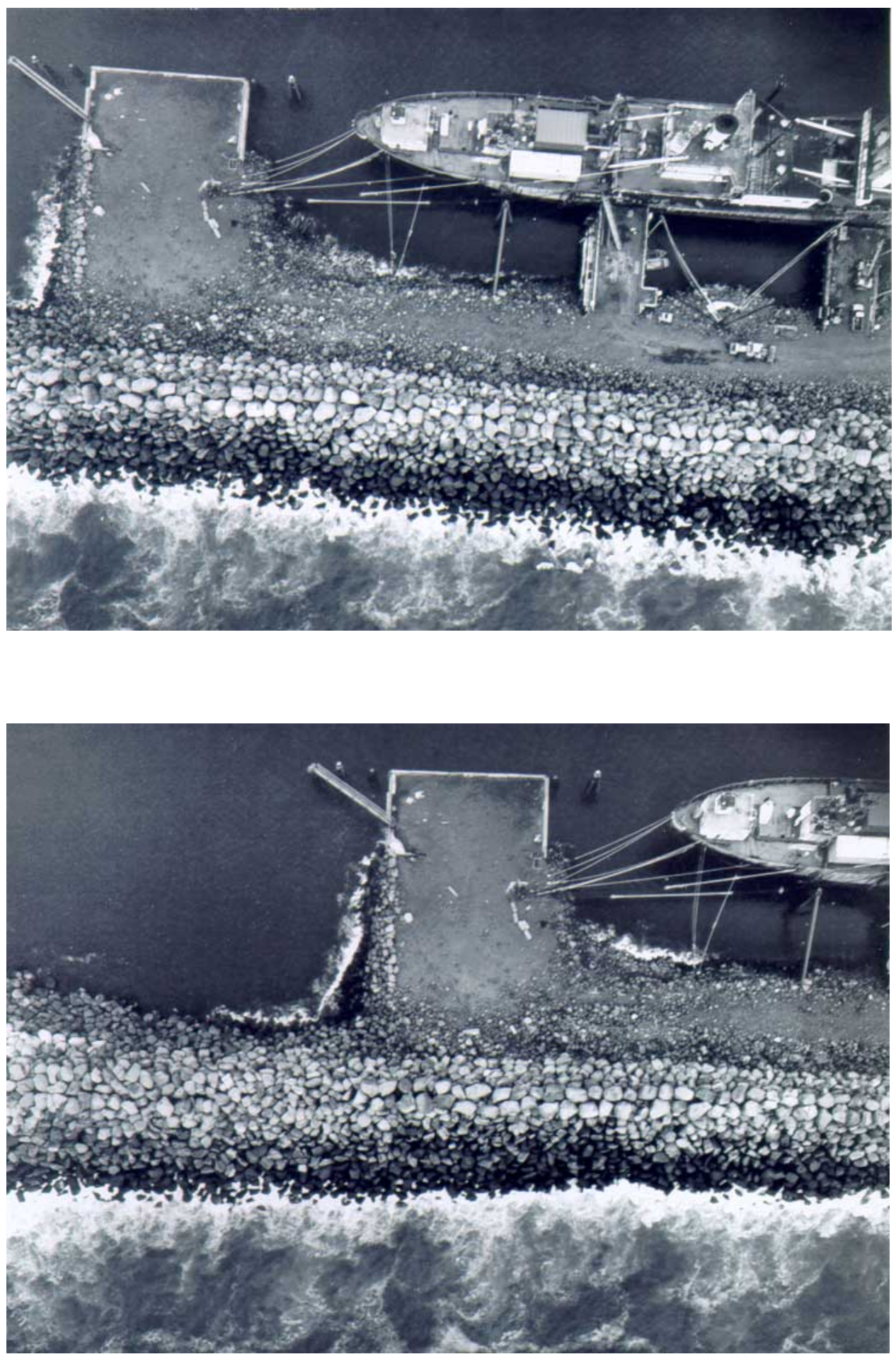

Figure $8 . \quad$ (Sheet 2 of 3 ) 

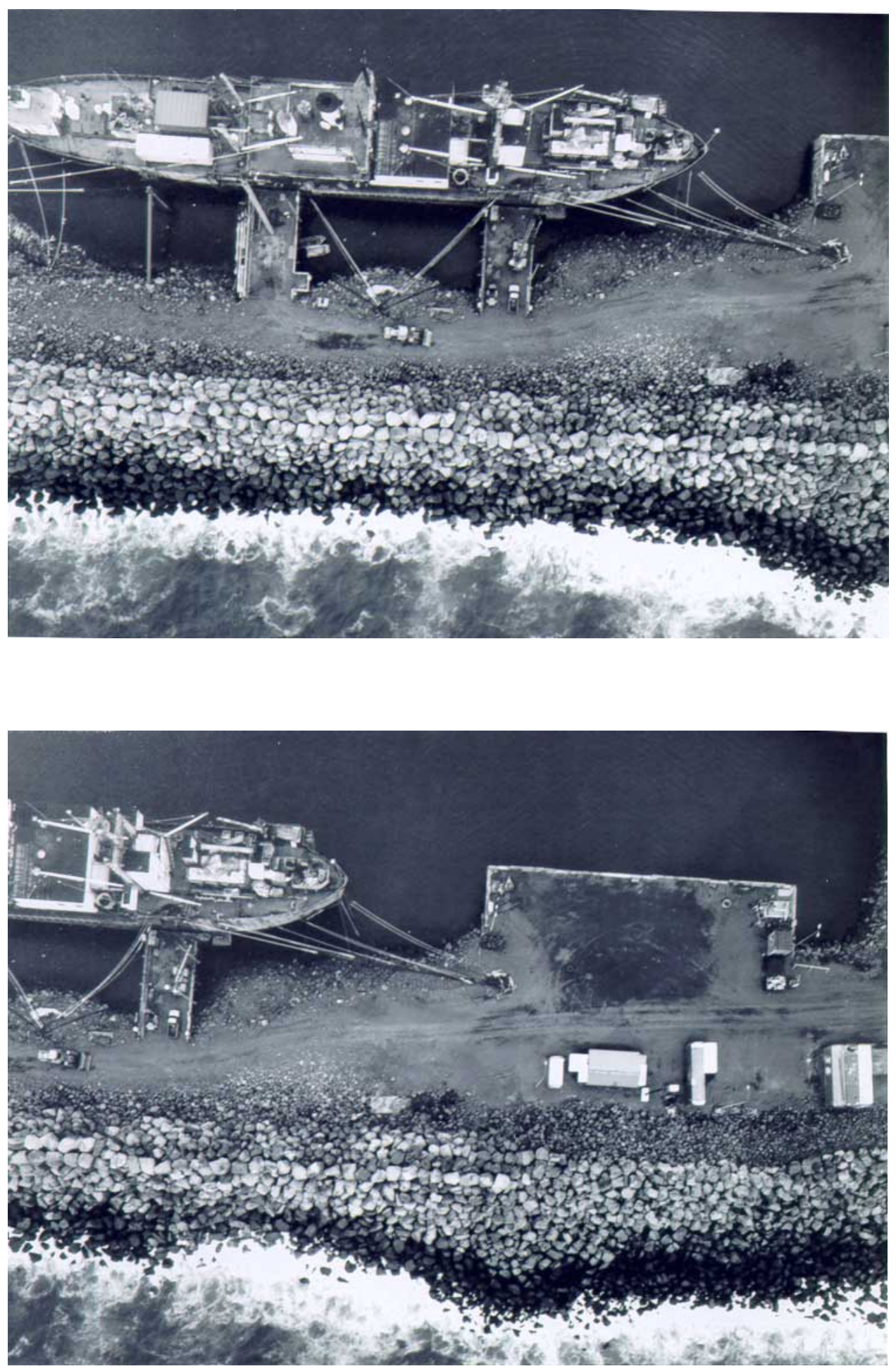

Figure 8. (Sheet 3 of 3 ) 


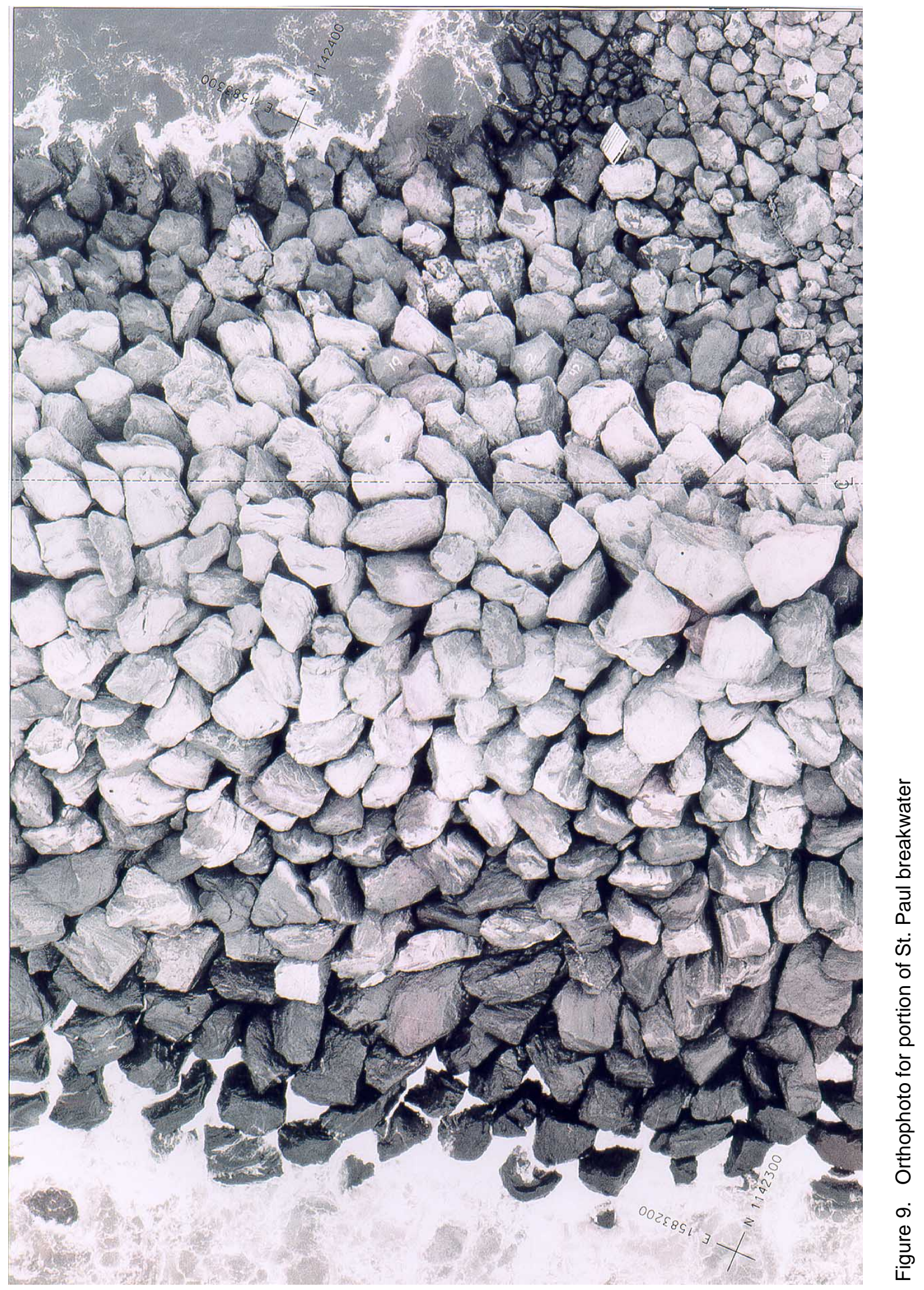


plot maps consisted of an approximately 0.46-m (1.5-ft) grid pattern overlaid on the structure. Precise vertical and horizontal measurements were obtained at the intersections of the grid. An example of a point plot map showing elevations on the breakwater is shown in Figure 10. Contour maps of the breakwater, developed from the DTM, for a 0.3-m (1-ft) contour interval are shown in Appendix A. Difference contours between the 1996 and 2000 surveys also were developed (example shown in Figure 11). In addition, using the analytical stereoplotter and DTM grid, cross sections of the breakwater were developed along the trunk of the breakwater at $15.2-\mathrm{m}(50-\mathrm{ft})$ intervals. These cross sections are compared with 1996 as well as 1994 data and are presented in Appendix B.

An examination of the breakwater topography for 2000 (Appendix A) reveals low areas along much of the breakwater. About 5 percent of the higher portion of the structure (sta $7+50-15+10)$ is at its design el of $+11.3 \mathrm{~m}(+37 \mathrm{ft})$, and 9 percent of the lower portion of the breakwater (sta 15+10 - 18+00) is at its design el of $+9.1 \mathrm{~m}(+30 \mathrm{ft})$. For the higher portion of the structure, the el of about 25 percent of the length of the breakwater is with $0.3 \mathrm{~m}(1.0 \mathrm{ft})$ of its design el, or between +11 and $+11.3 \mathrm{~m}(+36$ and $+37 \mathrm{ft})$; and approximately 66 percent of the structure is between +10.7 and $+11.3 \mathrm{~m}(+35$ and $+37 \mathrm{ft})$, or within $0.61 \mathrm{~m}(2 \mathrm{ft})$ of its design el. About 29 percent of the structure length is below $+10.7 \mathrm{~m}(+35 \mathrm{ft})$. For the lower portion of the structure, the el of about 50 percent of the length of the breakwater is within $0.3 \mathrm{~m}(1.0 \mathrm{ft})$ of its design el, or between +8.8 and $+9.1 \mathrm{~m}(+29$ and $+30 \mathrm{ft})$; and approximately 88 percent of the structure is within $0.61 \mathrm{~m}(2 \mathrm{ft})$ of its design el, or between +8.5 and $+9.1 \mathrm{~m}$ $(+28$ and $+30 \mathrm{ft})$. Only 3 percent of this portion of the structure length is below $+8.5 \mathrm{~m}(+28 \mathrm{ft})$. In general, these data indicate essentially no change in the crest el of the breakwater since 1996. None of the previous percentages changed more than one percentage point since the last survey.

Maps developed depicting changes in contours between 1996 and 2000 revealed several areas in the breakwater where voids or subsisdence (on the order of at least $1.5 \mathrm{~m}(5 \mathrm{ft}))$ have occurred. On the seaward slope, decreases in breakwater el were noted between sta $7+70$ and $8+45$ and sta $8+80$ and $9+70$; and on the shoreward slope between sta $8+80$ and $9+30$ and sta $13+90$ and $14+15$. Difference contour maps also revealed voids in several areas along both slopes of the breakwater as well as the crest where single armor units have been displaced.

Examination of breakwater cross sections (Appendix B) reveals low areas in the breakwater based on data obtained in 2000 versus that of 1994 and 1996. The overall shape and elevation of the strucure appear to be generally the same, but voids were noted in most cross sections of the current (2000) survey that were not present in the previous ones. Some of these voids were located on the crest of the structure and others along the slopes. The breakwater appears to have lost stones in these low areas.

Data provided in Appendices A and B include the above-water portion of the breakwater which was developed during the photogrammetric analysis. These data will continue to be used for comparisons with subsequent surveys under the Periodic Inspections work unit. Full-scale hard copies of aerial photographs, 


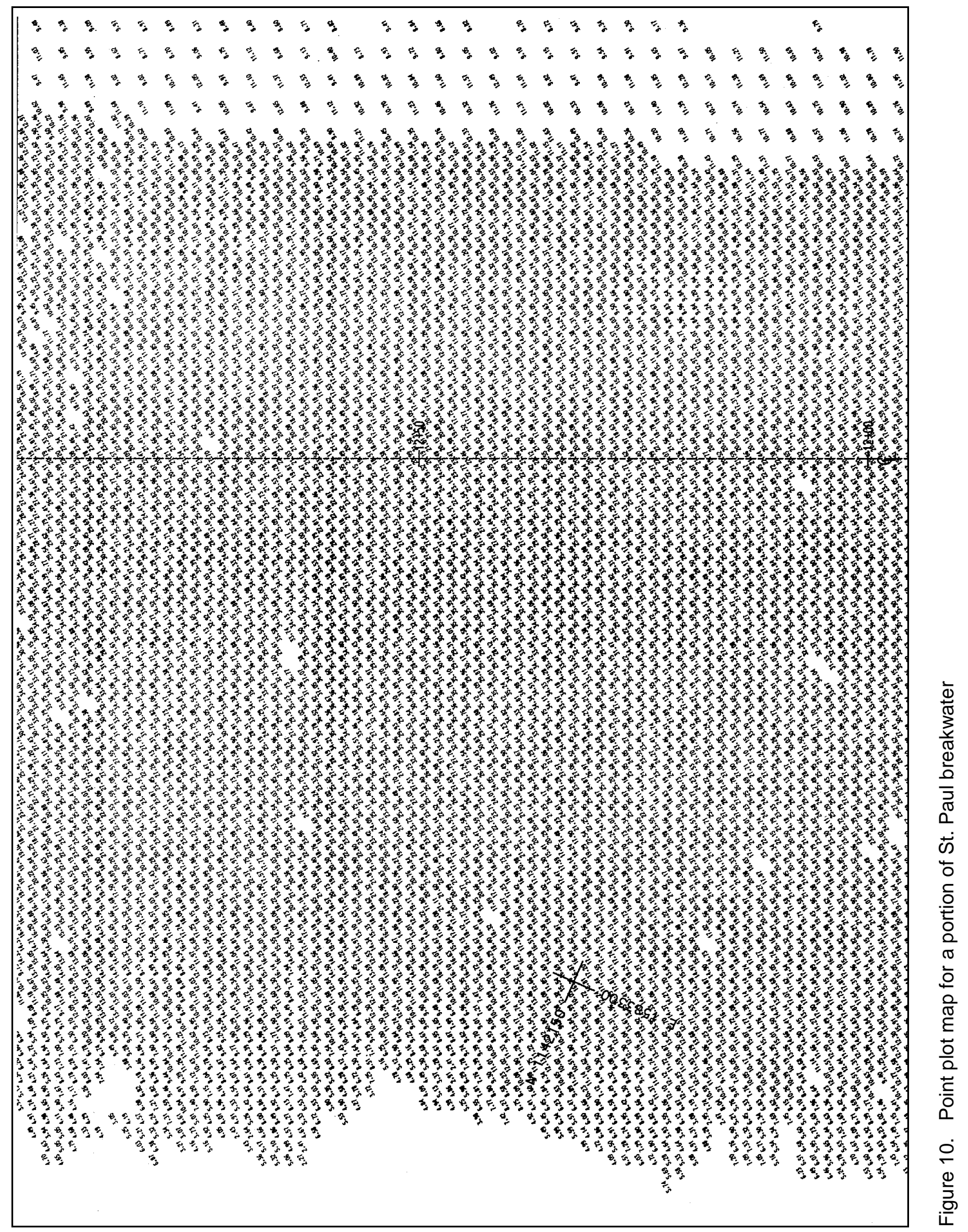

Chapter 3 Current Monitoring Plan and Data 


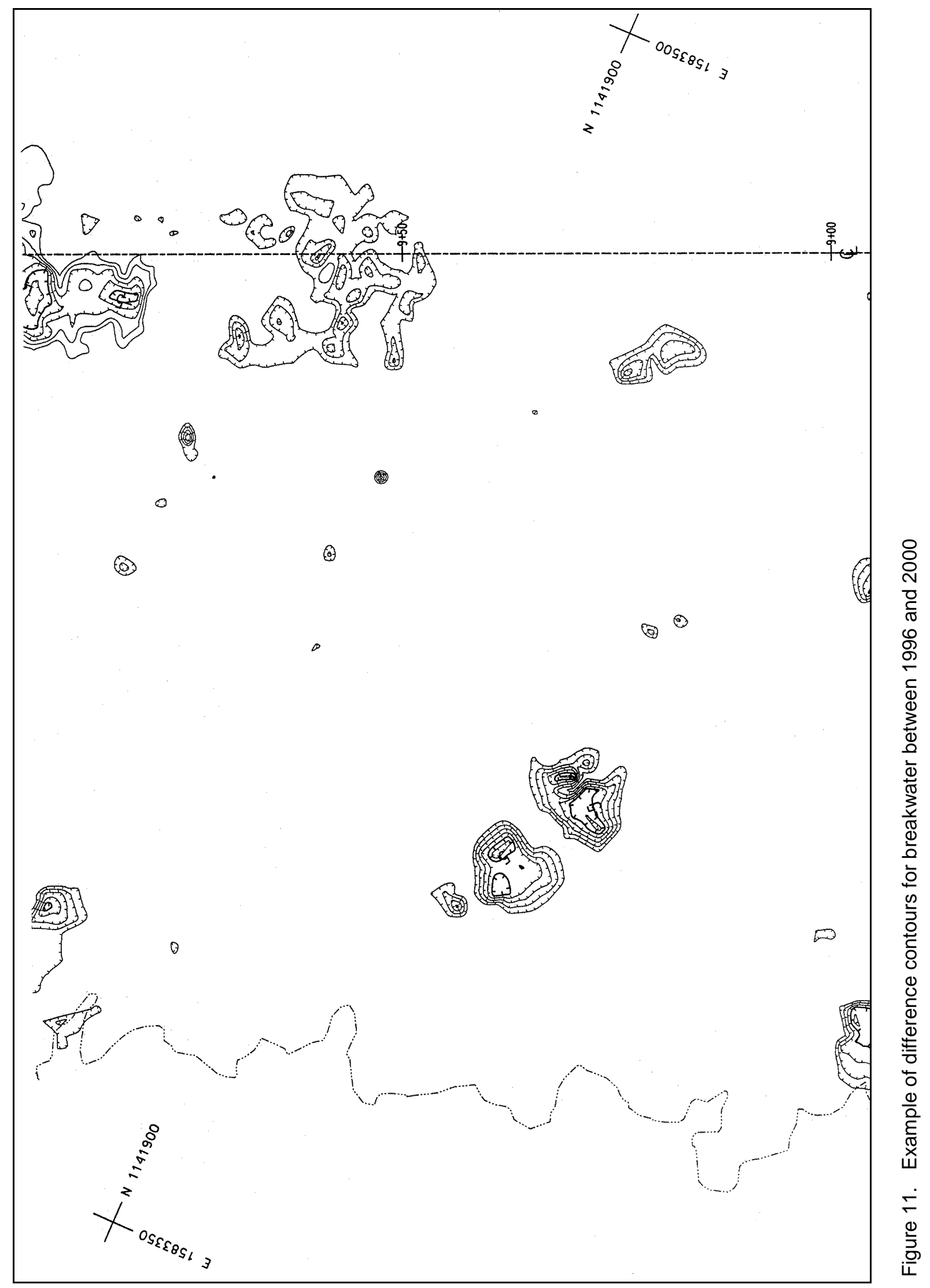


point plot maps, contour maps, cross sections, and orthophotos are on file at the authors' offices at CHL and the Alaska District. In addition, all photogrammetric compilations and analysis and map data have been stored on diskettes in InterGraph files for future use.

In summary, very detailed and accurate information relative to the armor stone positions for the St. Paul Harbor breakwater have been captured by means of aerial photography and photogrammetric analysis. Data are stored on diskettes and can be retrieved and compared against data obtained during subsequent monitoring. Thus, armor unit movement data may continue to be quantified precisely in future years.

\section{Broken Armor Stone Survey}

During the period 25-26 July 2000, a survey was conducted of broken/ cracked armor stones above the waterline on the 320-m-long (1,050-ft-long) St. Paul Harbor north outer breakwater. During the inspection, each broken armor stone was identified and photographed, and its approximate location relative to breakwater station and distance from a baseline was recorded. The baseline was the approximate center line of the structure. Armor stones with hairline cracks were not counted; only those that were cracked all the way through were counted. Views of representative types of breaks are shown in Figures 12-15. The data recorded during the broken armor stone inventory is shown in Table 2.

The survey revealed a total of 221 broken or cracked armor stones above the waterline. A total of 219 broken stones was noted on the trunk of the breakwater with only two observed around the head of the structure. Of the 219 stones along the trunk, 55 were located along the breakwater crest, 95 on the sea side slope, and 69 on the harbor side slope. The distribution of broken armor stones along the breakwater trunk as a function of station number and offset from the baseline is shown in Figure 16. Broken stones were, in general, relatively evenly distributed along the length of the structure. The survey indicated that 54 percent of the broken stones were located on the shoreward half of the breakwater extension and 46 percent were on the outer half. About 25 percent of the observed stones were along the crest, 43 percent on the seaward slope, and 32 percent on the harbor side slope. Of the broken stones located on the breakwater slopes, the survey revealed that 44 percent of the broken stones were located on the upper half of the slopes ( 28 percent on the sea side and 16 percent on the harbor side; and 56 percent were on the lower half of the structure slopes ( 30 percent on the sea side and 26 percent on the harbor side). The distribution of broken/cracked armor units relative to offset from the baseline is shown in Figure 17.

During the broken armor stone survey, 24 new broken stones were noted since the June 1996 inspection. Of the 24 new broken stones, nine were located along the crest, nine on the sea side slope, and five on the harbor side slope. In addition, a total of 33 broken stones, documented during the June 1996 survey, could not be found during the current inspection, indicating they had been moved 


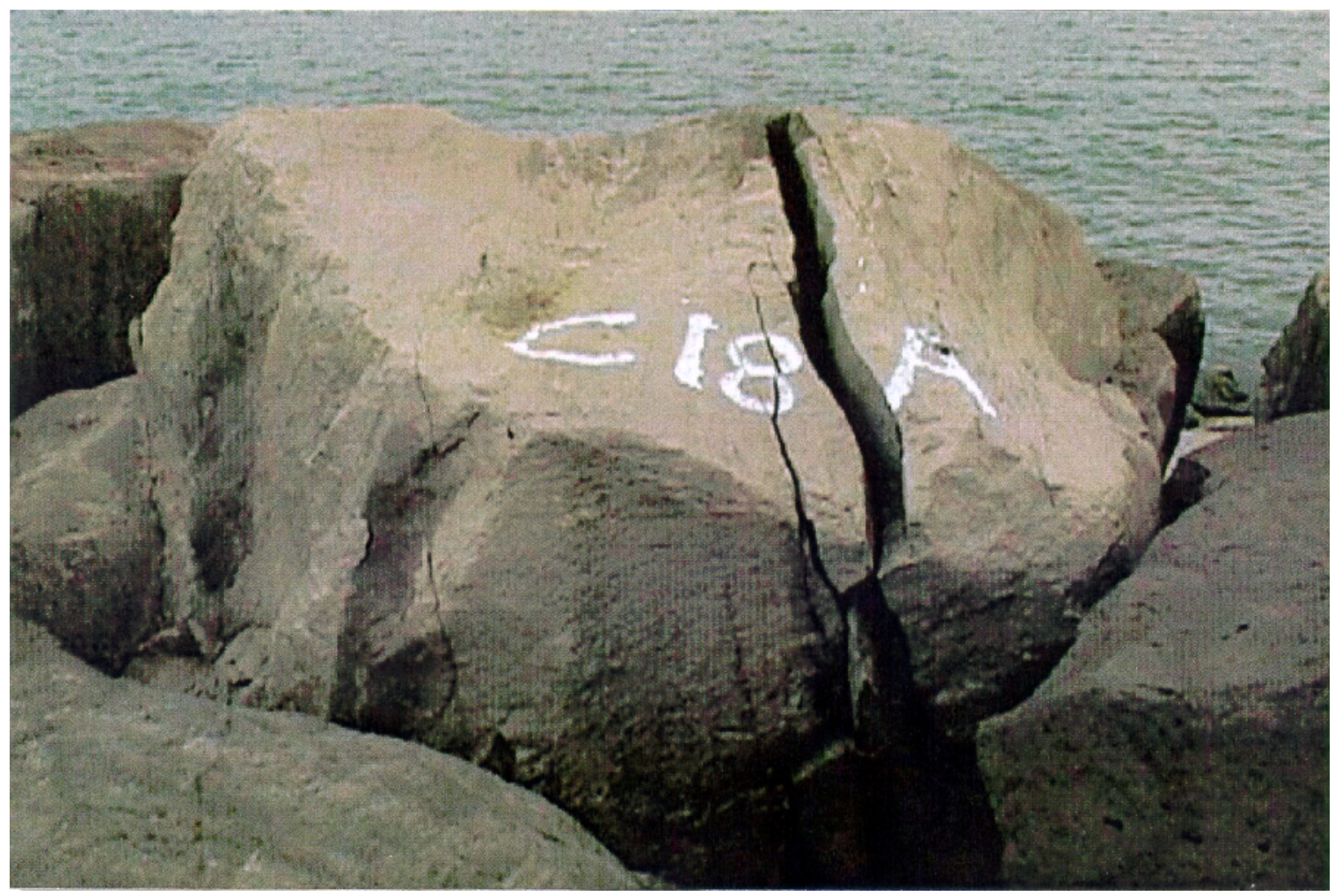

Figure 12. View of broken armor stone on St. Paul Harbor breakwater (sta 9+61)

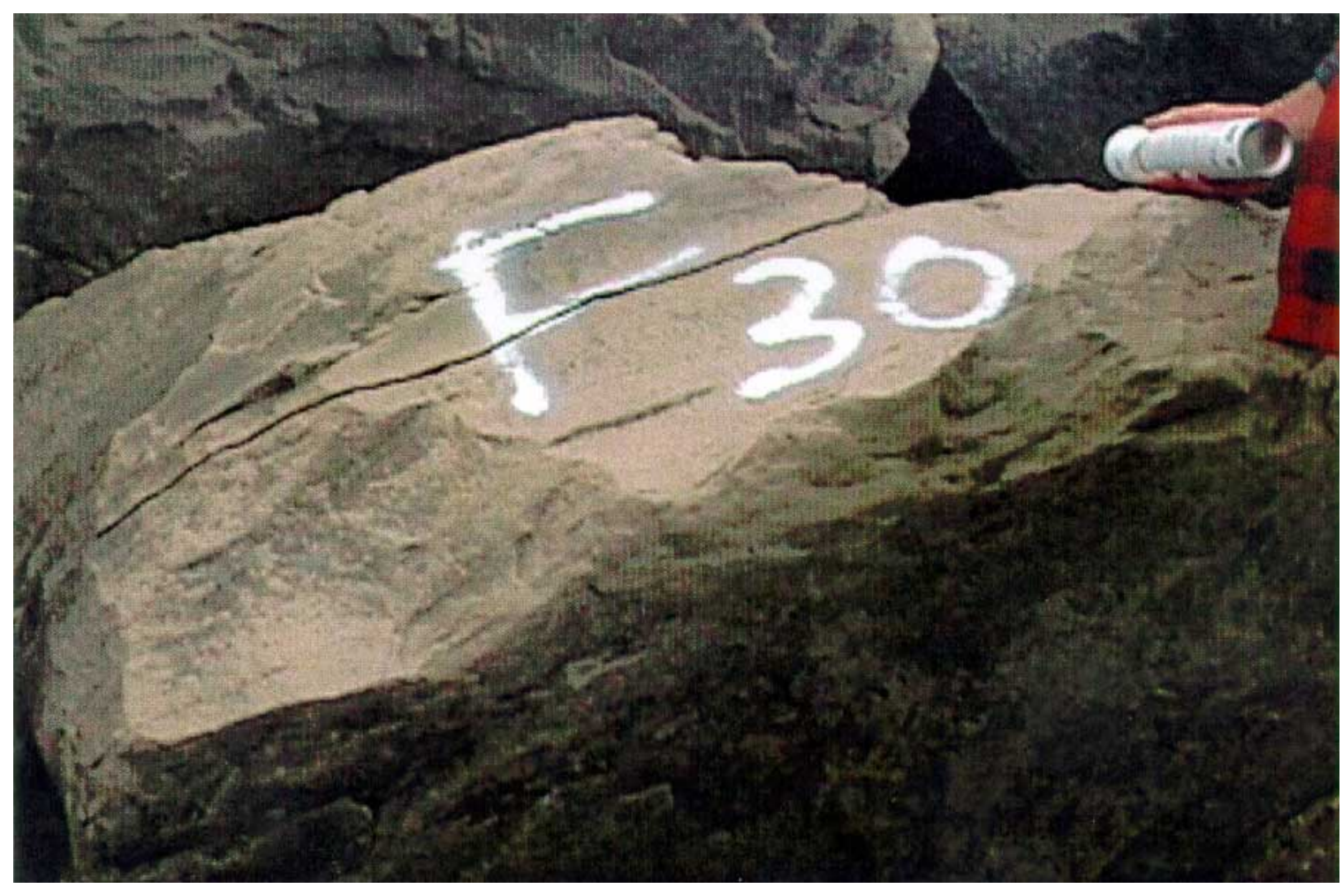

Figure 13. View of broken armor stone on St. Paul Harbor breakwater (sta 11+03) 


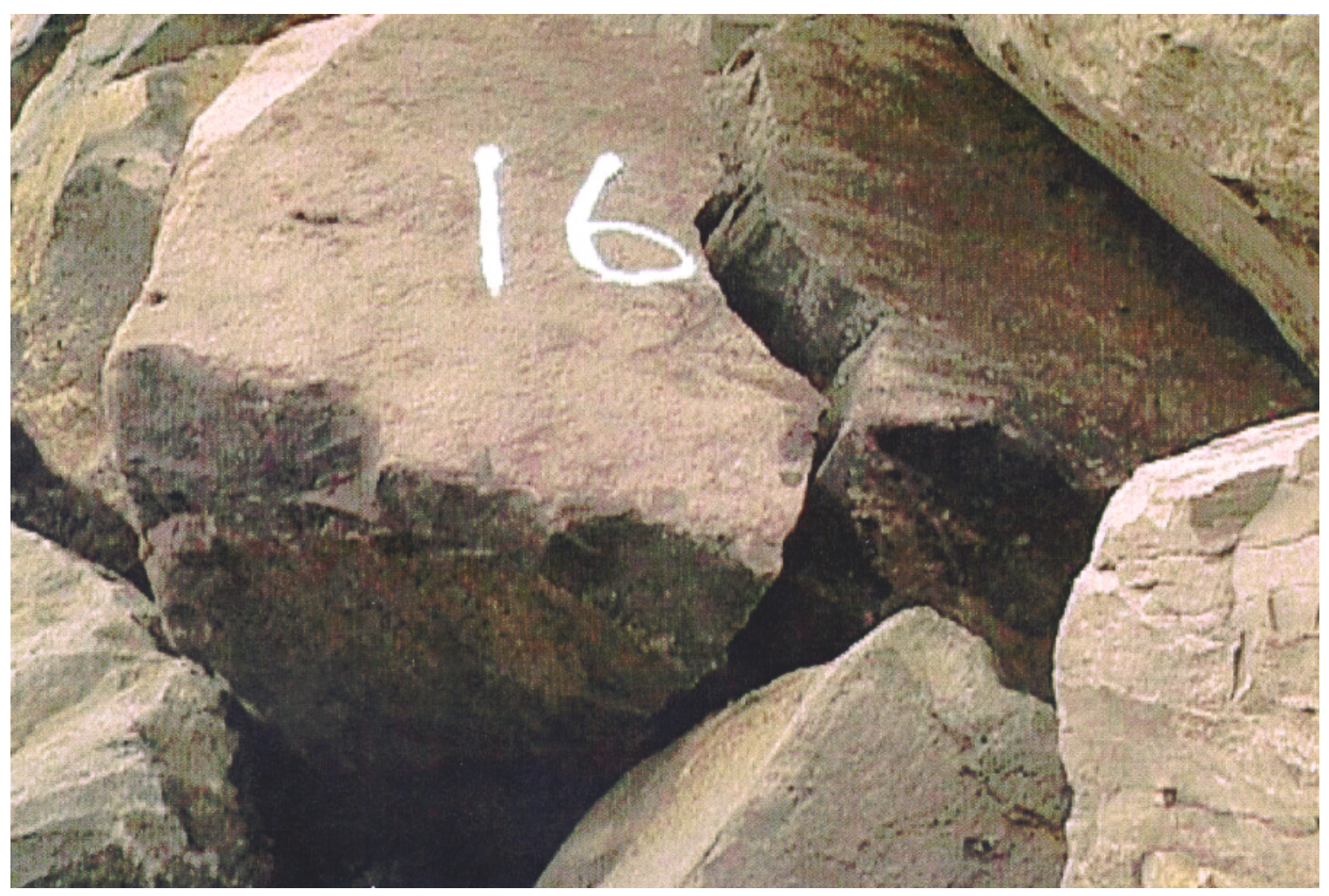

Figure 14. View of broken armor stone on St. Paul Harbor breakwater (sta 16+08)

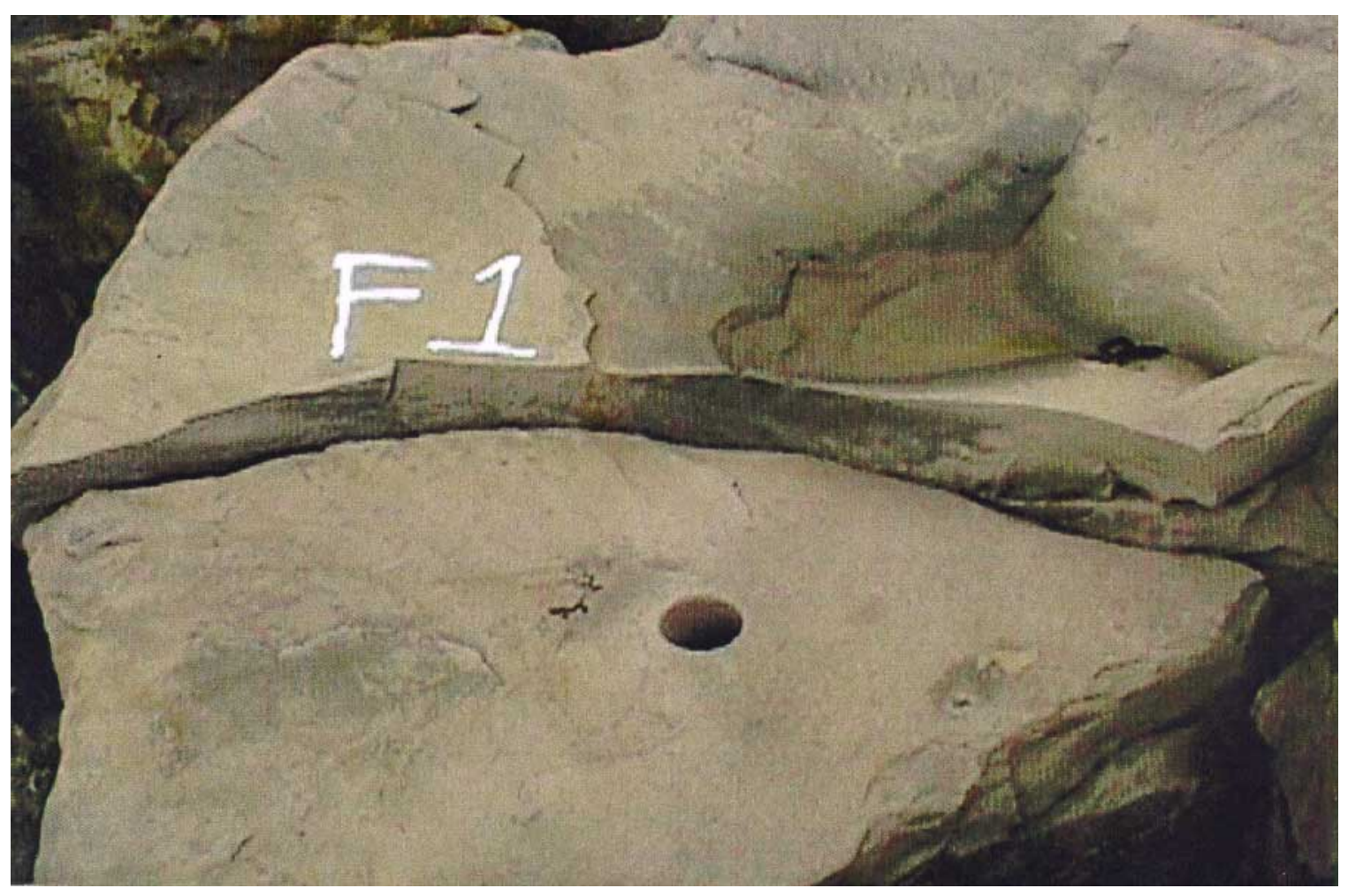

Figure 15. View of broken armor stone on St. Paul Harbor breakwater (sta 17+34) 


\begin{tabular}{|c|c|c|c|c|c|c|c|}
\hline \begin{tabular}{|l} 
Table \\
Broke
\end{tabular} & 2 & Stone Inv & entory, Ju & y 2000 & & & \\
\hline & & $\begin{array}{r}\text { Distance fr } \\
\mathrm{m}\end{array}$ & $\begin{array}{l}\text { om Baseline } \\
\text { (ft) }\end{array}$ & & & $\begin{array}{r}\text { Distance fr } \\
\mathrm{m}\end{array}$ & $\begin{array}{l}\text { om Baseline } \\
\text { (ft) }\end{array}$ \\
\hline Station & Stone No. & Sea Side & Harbor Side & Station & Stone No. & Sea Side & Harbor Side \\
\hline $7+56$ & 1 & & $\begin{array}{ll}3.0 & (10)\end{array}$ & $9+74$ & 56 & & $\begin{array}{ll}2.4 & (8)\end{array}$ \\
\hline $7+64$ & 2 & & $3.0 \quad(10)$ & $9+79$ & 57 & & $(19)$ \\
\hline $7+68$ & 3 & (14) & & $9+81$ & 58 & (14) & \\
\hline $7+78$ & 4 & $14.3 \quad(47)$ & & $9+81$ & 59 & (23) & \\
\hline $7+82$ & 5 & & $8.5 \quad(28)$ & $9+90$ & 60 & $(48)$ & \\
\hline $7+90$ & 6 & & $8.8 \quad(29)$ & $9+90$ & 61 & $(37)$ & \\
\hline $7+91$ & 7 & & $\begin{array}{ll}1.5 & (5)\end{array}$ & $9+95$ & 62 & (37) & \\
\hline $7+97$ & 8 & & $(30)$ & $9+98$ & 63 & & $\begin{array}{ll}9.8 & (32)\end{array}$ \\
\hline $7+99$ & 9 & & 2.4 & $10+08$ & 64 & 0.3 & \\
\hline $7+99$ & 10 & & $\begin{array}{ll}4.6 \quad(15) \\
\end{array}$ & $10+08$ & 65 & $\begin{array}{ll}6.7 & (22) \\
\end{array}$ & \\
\hline $8+10$ & 11 & $\begin{array}{ll}5.8 & (19) \\
\end{array}$ & & $10+12$ & 66 & & $\begin{array}{ll}1.8 & (6) \\
\end{array}$ \\
\hline $8+10$ & 12 & $(14)$ & & $10+21$ & 67 & (24) & \\
\hline $8+14$ & 13 & & $0.3 \quad(1)$ & $10+21$ & 68 & & $8.5 \quad(28)$ \\
\hline $8+15$ & 14 & & $\begin{array}{ll}8.8 & (29) \\
\end{array}$ & $10+23$ & 69 & (32) & \\
\hline $8+27$ & 15 & & $\begin{array}{ll}8.8 & (29)\end{array}$ & $10+23$ & 70 & & $\begin{array}{ll}7.0 & (23) \\
\end{array}$ \\
\hline $8+29$ & 16 & 13.4 & & $10+28$ & 71 & (28) & \\
\hline $8+35$ & 17 & (23) & & $10+33$ & 72 & $(12)$ & \\
\hline $8+44$ & 18 & & $1.5 \quad$ (5) & $10+38$ & 73 & $(27)$ & \\
\hline $8+44$ & 19 & & $8.2 \quad(27)$ & $10+50$ & 74 & (12) & \\
\hline $8+53$ & 20 & 10.1 & & $10+51$ & 75 & (15) & \\
\hline $8+57$ & 21 & 14.9 & & $10+71$ & 76 & $(41)$ & \\
\hline $8+57$ & 22 & & $\begin{array}{ll}3.0 & (10)\end{array}$ & $10+76$ & 77 & (12) & \\
\hline $8+60$ & 23 & & $7.3 \quad(24)$ & $10+76$ & 78 & 1.8 & \\
\hline $8+60$ & 24 & 1.2 & & $10+78$ & 79 & 1.2 & \\
\hline $8+63$ & 25 & (31) & & $10+80$ & 80 & (45) & \\
\hline $8+63$ & 26 & 11.3 & & $10+88$ & 81 & & $\begin{array}{ll}1.5 & (5)\end{array}$ \\
\hline $8+71$ & 27 & 10.1 & & $10+90$ & 82 & (21) & \\
\hline $8+72$ & 28 & & 1.8 & $10+90$ & 83 & & $10.7 \quad(35)$ \\
\hline $8+79$ & 29 & & $\begin{array}{ll}1.8 & (6)\end{array}$ & $10+94$ & 84 & & $\begin{array}{ll}2.7 & (9) \\
\end{array}$ \\
\hline $8+83$ & 30 & & $(20)$ & $11+00$ & 85 & (10) & \\
\hline $8+84$ & 31 & & $(10)$ & $11+03$ & 86 & $\begin{array}{ll}6.7 & \text { (22) } \\
\end{array}$ & \\
\hline $8+86$ & 32 & & $4.6 \quad(15)$ & $11+06$ & 87 & & (11) \\
\hline $8+97$ & 33 & & 2.4 & $11+27$ & 88 & (48) & \\
\hline $9+07$ & 34 & $(26)$ & & $11+31$ & 89 & (16) & \\
\hline $9+10$ & 35 & & $\begin{array}{ll}7.9 & (26) \\
\end{array}$ & $11+32$ & 90 & & (32) \\
\hline $9+12$ & 36 & 0.3 & & $11+40$ & 91 & & (32) \\
\hline $9+22$ & 37 & & $\begin{array}{ll}7.0 & (23)\end{array}$ & $11+44$ & 92 & (30) & \\
\hline $9+22$ & 38 & $(1)$ & & $11+44$ & 93 & (18) & \\
\hline $9+28$ & 39 & & $\begin{array}{ll}7.6 & (25) \\
\end{array}$ & $11+46$ & 94 & $14.0 \quad(46)$ & \\
\hline $9+34$ & 40 & (14) & & $11+78$ & 95 & & $(26)$ \\
\hline $9+36$ & 41 & & (28) & $11+78$ & 96 & & $4.6 \quad(15)$ \\
\hline $9+37$ & 42 & & 2.1 & $11+83$ & 97 & (43) & \\
\hline $9+44$ & 43 & & 2.7 & $11+87$ & 98 & 1.2 (4) & \\
\hline $9+44$ & 44 & & $\begin{array}{ll}3.0 & (10)\end{array}$ & $11+94$ & 99 & $(40)$ & \\
\hline $9+53$ & 45 & $(17)$ & & $11+99$ & 100 & (23) & \\
\hline $9+53$ & 46 & (12) & & $12+00$ & 101 & (40) & \\
\hline $9+54$ & 47 & 14.3 & & $12+06$ & 102 & & $\begin{array}{ll}4.6 & (15) \\
\end{array}$ \\
\hline $9+55$ & 48 & $(11)$ & & $12+13$ & 103 & (21) & \\
\hline $9+58$ & 49 & $6.4 \quad(21)$ & & $12+15$ & 104 & (10) & \\
\hline $9+58$ & 50 & & $4.9 \quad(16)$ & $12+15$ & 105 & (20) & \\
\hline $9+59$ & 51 & $\begin{array}{ll}4.0 & (13) \\
\end{array}$ & & $12+26$ & 106 & & $(12)$ \\
\hline $9+61$ & 52 & $0.3 \quad(1)$ & & $12+31$ & 107 & & (22) \\
\hline $9+68$ & 53 & & (19) & $12+32$ & 108 & $(40)$ & \\
\hline $9+73$ & 54 & $(10)$ & & $12+35$ & 109 & (11) & \\
\hline $9+73$ & 55 & $\begin{array}{ll}10.7 & (35) \\
\end{array}$ & & $12+43$ & 110 & $(24)$ & \\
\hline & & & & & & & (Continu \\
\hline
\end{tabular}




\begin{tabular}{|c|c|c|c|c|c|c|c|}
\hline \multirow[b]{2}{*}{ Station } & \multirow[b]{2}{*}{ Stone No. } & \multicolumn{2}{|c|}{$\begin{array}{c}\text { Distance from Baseline } \\
m(\mathrm{ft})\end{array}$} & \multirow[b]{2}{*}{ Station } & \multirow[b]{2}{*}{ Stone No. } & \multicolumn{2}{|c|}{$\begin{array}{c}\text { Distance from Baseline } \\
m(\mathrm{ft})\end{array}$} \\
\hline & & \begin{tabular}{|l} 
Sea Side \\
\end{tabular} & Harbor Side & & & Sea Side & Harbor Side \\
\hline $12+44$ & 111 & (43) & & $15+34$ & 167 & (30) & \\
\hline $12+44$ & 112 & $11.3 \quad(37)$ & & $15+34$ & 168 & $12.2 \quad(40)$ & \\
\hline $12+46$ & 113 & $(38)$ & & $15+45$ & 169 & & $\begin{array}{ll}11.3 \quad(37) \\
\end{array}$ \\
\hline $12+49$ & 114 & $12.2 \quad(40)$ & & $15+48$ & 170 & & $7.3(24)$ \\
\hline $12+50$ & 115 & & 12.2 & $15+50$ & 171 & & 9.8 \\
\hline $12+54$ & 116 & & 1.8 & $15+53$ & 172 & 0.6 & \\
\hline $12+55$ & 117 & & 1.8 & $15+57$ & 173 & $2.4 \quad(8)$ & \\
\hline $12+62$ & 118 & & (12) & $15+59$ & 174 & & (23) \\
\hline $12+70$ & 119 & $(10)$ & & $15+65$ & 175 & (15) & \\
\hline $12+72$ & 120 & 11.3 & & $15+68$ & 176 & 0.9 & \\
\hline $12+77$ & 121 & $(16)$ & & $15+71$ & 177 & & $1.5 \quad(5)$ \\
\hline $12+85$ & 122 & & $(12)$ & $15+72$ & 178 & & (2) \\
\hline $12+87$ & 123 & $(26)$ & & $15+72$ & 179 & $5.5 \quad(18)$ & \\
\hline $13+03$ & 124 & & 1.5 & $15+78$ & 180 & $\begin{array}{ll}2.4 & (8)\end{array}$ & \\
\hline $13+04$ & 125 & (20) & & $15+83$ & 181 & & (26) \\
\hline $13+04$ & 126 & $(30)$ & & $15+91$ & 182 & $\begin{array}{ll}7.6 & (25)\end{array}$ & \\
\hline $13+05$ & 127 & 1.5 & & $15+91$ & 183 & & 13.1 \\
\hline $13+05$ & 128 & & $(18)$ & $15+99$ & 184 & $10.7 \quad(35)$ & \\
\hline $13+10$ & 129 & (17) & & $16+00$ & 185 & & 11.9 \\
\hline $13+10$ & 130 & & 10.7 & $16+04$ & 186 & & (1) \\
\hline $13+17$ & 131 & 0.3 & & $16+05$ & 187 & $(13)$ & \\
\hline $13+21$ & 132 & & (25) & $16+06$ & 188 & $(22)$ & \\
\hline $13+36$ & 133 & & 1.5 & $16+08$ & 189 & & (29) \\
\hline $13+38$ & 134 & (18) & & $16+13$ & 190 & & 10.7 \\
\hline $13+40$ & 135 & 10.4 & & $16+26$ & 191 & & (32) \\
\hline $13+43$ & 136 & $(17)$ & & $16+29$ & 192 & (30) & \\
\hline $13+43$ & 137 & (23) & & $16+29$ & 193 & $(20)$ & \\
\hline $13+50$ & 138 & & (20) & $16+32$ & 194 & & (20) \\
\hline $13+50$ & 139 & 1.5 & & $16+34$ & 195 & $(12)$ & \\
\hline $13+55$ & 140 & & 0.3 & $16+40$ & 196 & $10.4 \quad(34)$ & \\
\hline $13+62$ & \begin{tabular}{|l|l|}
141 \\
\end{tabular} & & 2.7 & $16+41$ & \begin{tabular}{|l}
197 \\
\end{tabular} & & 13.7 \\
\hline $13+80$ & 142 & (17) & & $16+45$ & 198 & & 10.1 \\
\hline $13+83$ & 143 & $(19)$ & & $16+49$ & 199 & (27) & \\
\hline $14+04$ & 144 & 0.9 & & $16+49$ & 200 & 12.2 & \\
\hline $14+04$ & 145 & & (10) & $16+54$ & 201 & & (25) \\
\hline $14+05$ & 146 & & $(20)$ & $16+55$ & 202 & & 14.3 \\
\hline $14+12$ & 147 & & (30) & $16+56$ & 203 & $\begin{array}{ll}7.6 & (25)\end{array}$ & \\
\hline $14+23$ & 148 & (22) & & $16+59$ & 204 & & 13.7 \\
\hline $14+25$ & 149 & 12.8 & & $16+59$ & 205 & & (25) \\
\hline $14+42$ & 150 & $(30)$ & & $16+84$ & 206 & & $(26)$ \\
\hline $14+43$ & 151 & & $(14)$ & $16+87$ & 207 & $\begin{array}{ll}7.6 & (25)\end{array}$ & \\
\hline $14+54$ & 152 & $(12)$ & & $16+90$ & 208 & & (1) \\
\hline $14+62$ & 153 & 2.4 & & $16+99$ & 209 & & 13.7 \\
\hline $14+70$ & 154 & & (20) & $17+00$ & 210 & 2.4 & \\
\hline $14+74$ & 155 & $(12)$ & & $17+09$ & 211 & & 11.6 \\
\hline $14+75$ & 156 & & (23) & $17+11$ & 212 & & 11.9 \\
\hline $14+80$ & 157 & (25) & & $17+21$ & 213 & & 16.8 \\
\hline $14+81$ & 158 & 1.5 & & $17+26$ & 214 & & $(10)$ \\
\hline $14+82$ & 159 & & (22) & $17+34$ & 215 & 12.5 & \\
\hline $14+91$ & 160 & (14) & & $17+34$ & 216 & $11.9 \quad(39)$ & \\
\hline $15+12$ & 161 & & (26) & $17+37$ & 217 & & (30) \\
\hline $15+20$ & 162 & $\begin{array}{ll}3.0 & (10)\end{array}$ & & $17+38$ & 218 & $(18)$ & \\
\hline $15+23$ & 163 & & (27) & $17+85$ & 219 & $3.0 \quad(10)$ & \\
\hline $15+23$ & 164 & & (17) & $18++$ & 220 & & \\
\hline $15+27$ & 165 & & (27) & $18++$ & 221 & & \\
\hline $15+31$ & 166 & $(38)$ & & & & & \\
\hline
\end{tabular}




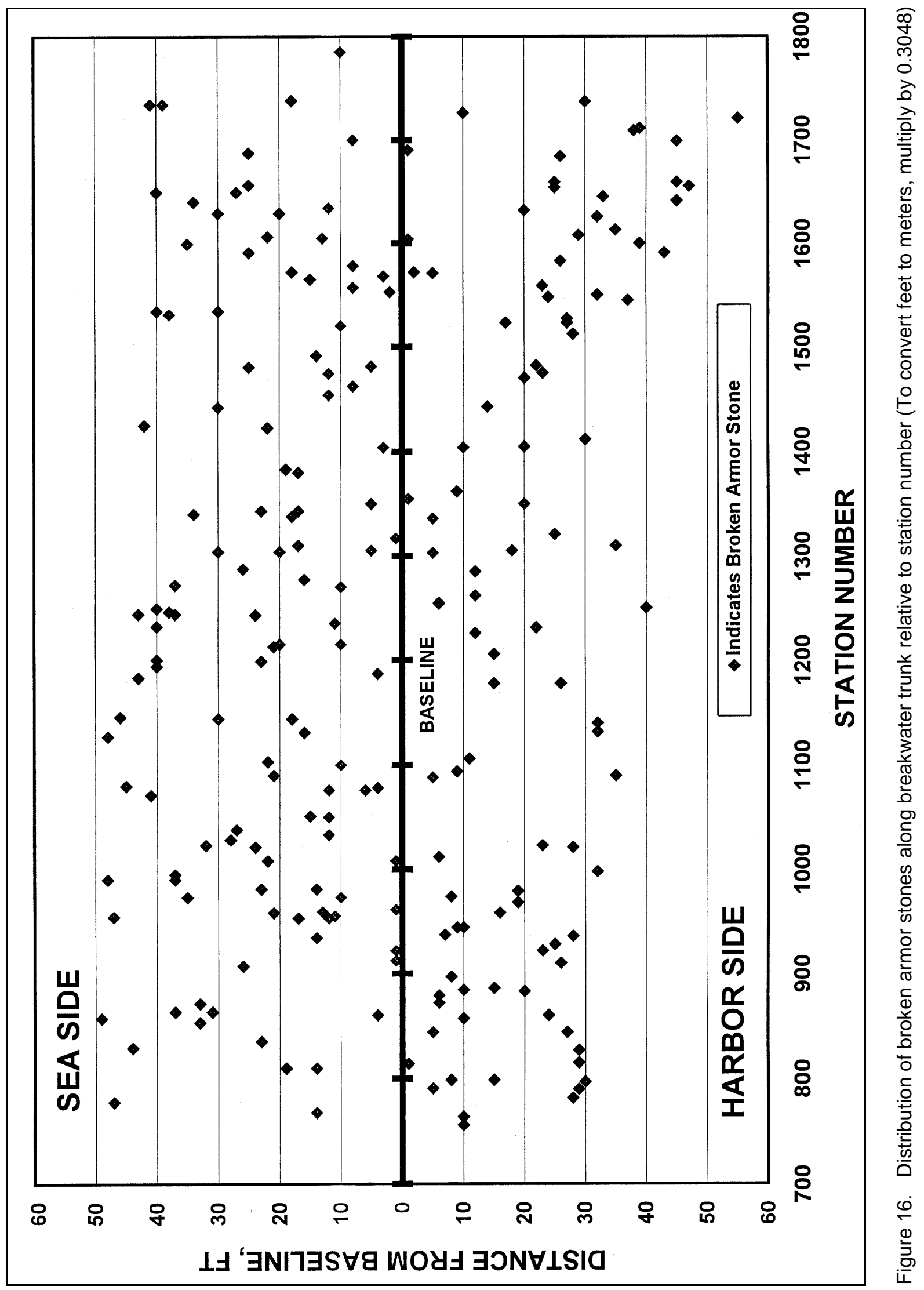




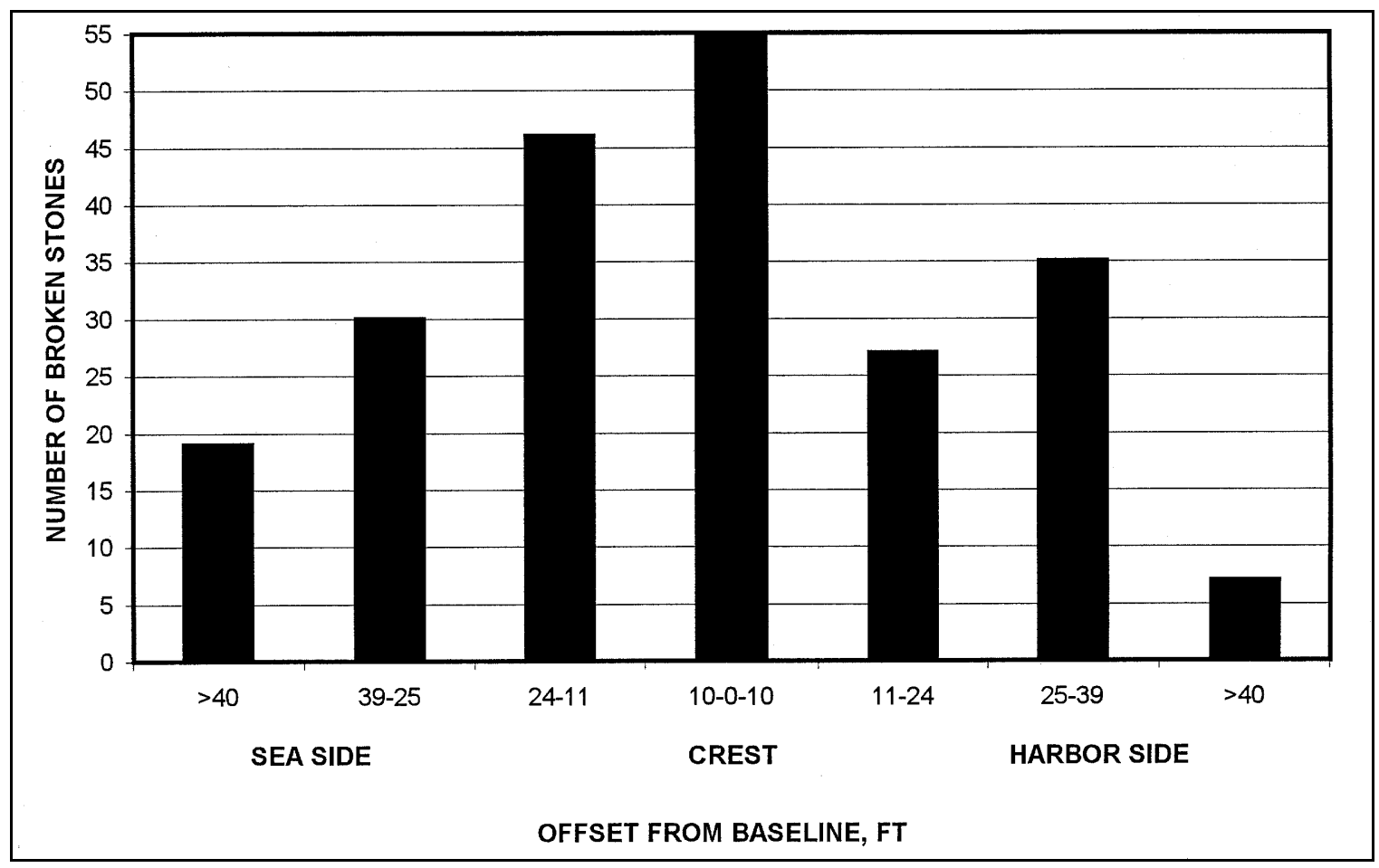

Figure 17. Distribution of broken armor stones relative to distance from baseline (To convert feet to meters, multiply by 0.3048 )

away by wave and/or ice action. Just fragments of most these stones remained. Of the 33 broken stones that could not be found, four had been located on the crest, 23 on the sea side slope, and six on the harbor side slope.

It was noted during the survey that the separated armor stones at sta $14+30$ at the northernmost dock were in approximately the same positions as noted during the May 1999 inspection. They were separated by several feet resulting in a void along the crest. Another obvious void observed during the survey was the area immediately upslope of the 25 new stones that were placed along the waterline on the sea side slope between stas $8+80$ and 9+70 in May 2000. The new stones appear to be stacked along the waterline, and some probably should have been positioned further upslope to cover the voids. Core stone is exposed in one area. Plans are to place additional stones in the voids as part of the offshore reef breakwater construction scheduled for completion in 2001.

The rate of stone breakage appears to have declined at St. Paul Harbor breakwater. Only 24 new broken armor stones were observed in the last 4-year period since the survey of June 1996 as opposed to 157 broken stones that occurred during the original 3-year monitoring period between July 1993 to June 1996. 


\section{Summary and Findings}

The St. Paul Harbor main breakwater was constructed to its current length $(549 \mathrm{~m}(1,800 \mathrm{ft}))$ in 1989. As part of a comprehensive monitoring effort, the structure was monitored under the MCNP program. During the period July 1993 through June 1996, detailed data of the above-water portion of the outer $320 \mathrm{~m}$ $(1,050 \mathrm{ft})$ of the main breakwater were obtained through limited ground surveys, aerial photography, photogrammetric analysis, and broken armor stone surveys.

Results of the initial monitoring effort revealed that most of the breakwater was below its design elevation (el) and that degradation of the armor stone progressed throughout the original monitoring time frame. Photogrammetric analysis revealed that only five percent of the higher portion of the breakwater (adjacent to the harbor roadway) was at its design el and that almost one-third was at least $0.61 \mathrm{~m}(2 \mathrm{ft})$ below its design el of $+11.3 \mathrm{~m}(+37 \mathrm{ft})$. Analysis also indicated essentially no change in the el of the breakwater crown between surveys of 1994 and 1996. The number of broken/cracked armor stones on the breakwater increased from 73 to 230 between 1993 and 1996. A geologic assessment revealed that a significant amount of the stone was either blastdamaged or geologically unacceptable. At the conclusion of the original monitoring study, the breakwater was functional and in good structural condition overall. Continued deterioraton was predicted, however, due to freeze-thaw and wet-dry cycles as well as large waves and sea ice action.

To minimize further breakwater damage and reduce overtopping of the main breakwater, the construction of submerged reef breakwaters seaward of the structure was initiated during the 2000 construction season. The current monitoring (2000), obtained under the Periodic Inspections work unit of the MCNP program, was conducted to determine changes in the armor unit field since the previous study and establish new base conditions since construction of the reef breakwaters.

The current monitoring entailed re-establishing targets and conducting limited ground-based surveys, aerial photography, and photogrammetric analysis of the St. Paul Harbor main breakwater for comparison against conditions obtained in 1996. The entire above-water armor unit field was analyzed and quantified through the use of high resolution, aerial stereo pair photographs, a stereoplotter, and Intergraph-based software. A detailed broken armor unit survey also was conducted during the current effort and compared to previous survey data. 
Results of the current (2000) monitoring effort indicated essentially no change in the overall breakwater crest elevation and shape of the structure since the 1996 survey. Although still below design elevation, the structure has not, in general, settled or subsided to any great extent. There are localized areas in the breakwater, however, where voids have occurred (likely due to the displacement of armor stones). Voids were noted on both slopes of the structure as well as the breakwater crest.

A total of 221 broken armor stones were documented during the 2000 survey versus 230 in 1996. Analysis indicated that 33 broken stones, documented in the 1996 survey, could not be found during 2000, suggesting they may have been moved away by wave and/or ice action. The rate of stone breakage appears to have declined. Only 24 new broken armor stones occurred in the past 4-year period versus 157 broken stones that occurred during the 1993-1996 time frame. As noted in the contour maps and breakwater cross sections developed through photogrammetry, voids due to displaced stones were visually observed in localized areas of the breakwater during the broken stone inventory.

The St. Paul Harbor main breakwater is currently functioning in an acceptable manner, with the exception of the excessive overtopping, and is considered to be in good condition structurally. Construction of the three offshore submerged reefs seaward of the breakwater, initiated during the summer of 2000, should provide additional protection from further wave induced damage and reduce overtopping. Subsequent inspections should be conducted to analyze the performance of the improved project. It is recommended that additional armor stone be placed in some of the apparent voids in the breakwater along with reef construction, particularly the large void between stas $8+80$ and $9+70$, where core stone is exposed.

In general, methodology has been developed to assess the long-term response of the St. Paul Harbor main breakwater to its environment. Further comparison of armor stone data in future years will be conducted under the Periodic Inspections work unit to gather data by which additional assessments can be made. Insight gathered from these efforts will allow engineering decisions to be made on sound data as to whether or not closer surveillance and/or repair of the structure might be required to reduce its chances of failing catastrophically. Also, the periodic inspection methods developed and validated for this breakwater may be used to gain insight into other Corps structures. 


\section{References}

Bottin, R. R., Jr. (1996). "Study of harbor improvements at St. Paul Harbor, St. Paul Island, Alaska; Coastal model investigation," Technical Report CERC-96-7, U.S. Army Engineer Waterways Experiment Station, Vicksburg, MS.

Bottin, R. R., Jr., and Eisses, K. J. (1997). "Monitoring of harbor improvements at St. Paul Harbor, St. Paul Island, Alaska," Technical Report CHL-97-13, U.S. Army Engineer Waterways Experiment Station, Vicksburg, MS.

Bottin, R. R., Jr., and Mize, M. G. (1988). "St. Paul Harbor, St. Paul Island, Alaska, design for wave and shoaling protection; Hydraulic model investigation," Technical Report CERC-88-13, U.S. Army Engineer Waterways Experiment Station, Vicksburg, MS.

Shore Protection Manual. (1984). 4th ed., 2 Vol, U.S. Army Engineer Waterways Experiment Station, U.S. Government Printing Office, Washington, DC.

Tetra Tech, Inc. (1987). "St. Paul Harbor and breakwater technical design report," TC-3263-07, Pasadena, CA; prepared for the City of St. Paul, AK.

U.S. Army Engineer District, Alaska. (1981). "St. Paul Island, Alaska; Harbor feasibility report," Anchorage, AK.

Ward, D. L. (1988). "St. Paul Harbor breakwater stability study, St. Paul, Alaska; Hydraulic model investigation," Technical Report CERC-88-10, U.S. Army Engineer Waterways Experiment Station, Vicksburg, MS. 


\section{Appendix A Breakwater Topography, 2000}

This appendix presents contour maps of the St. Paul Harbor breakwater extension as a result of the photogrammetric analysis conducted in 2000. Topography was developed using the digital terrain model (DTM) as stated in the main text of this report. The breakwater topography is shown on a $0.3-\mathrm{m}$ $(1.0-\mathrm{ft})$ contour interval. Elevations shown are in feet referred to mean lower low water (mllw) datum. To convert feet to meters, multiply by 0.3048 . Station numbering on the contour maps is from a southerly to northerly direction. 


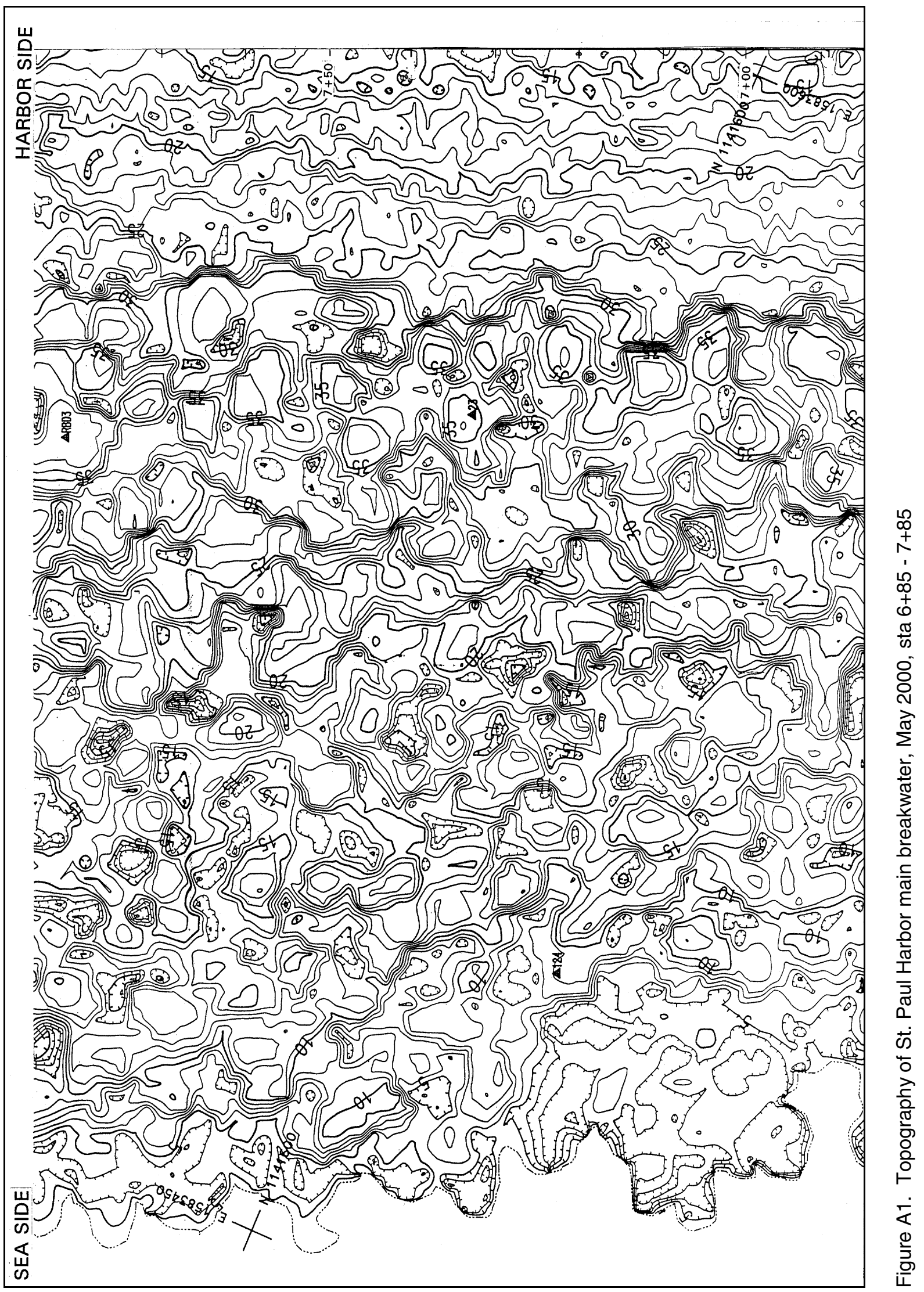




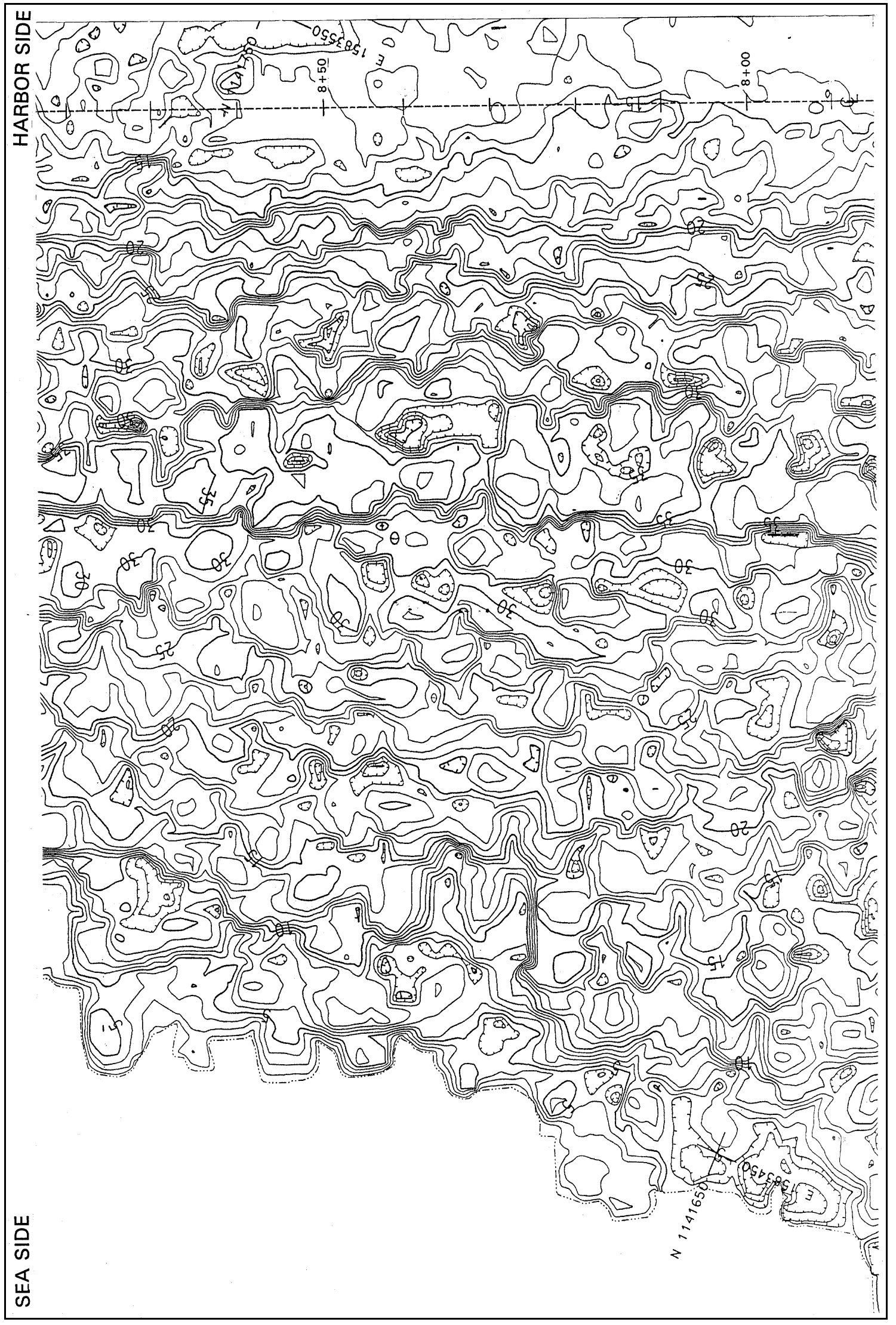

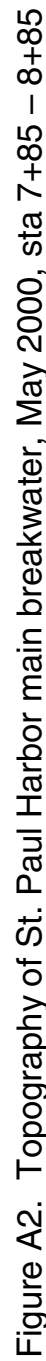




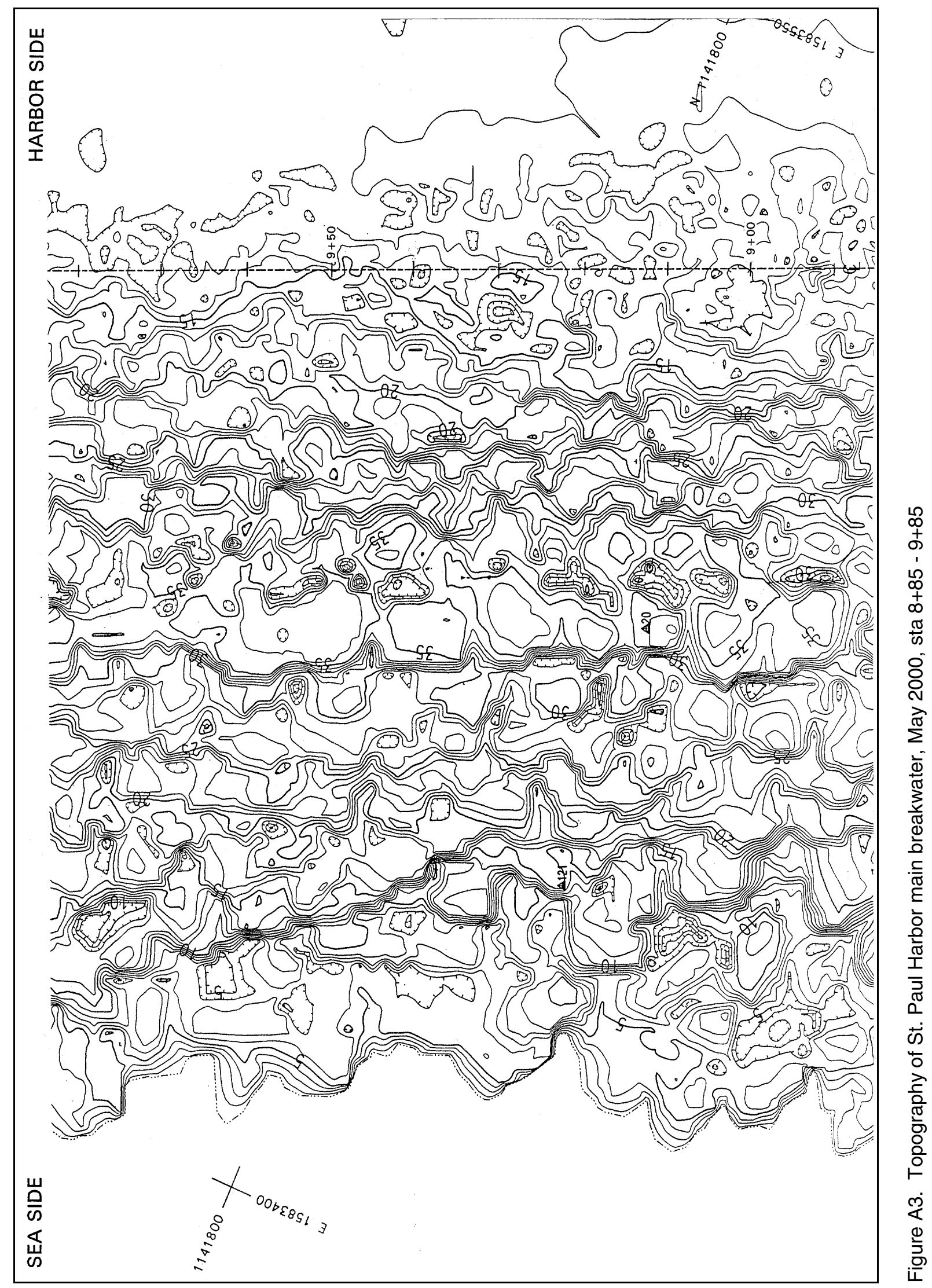




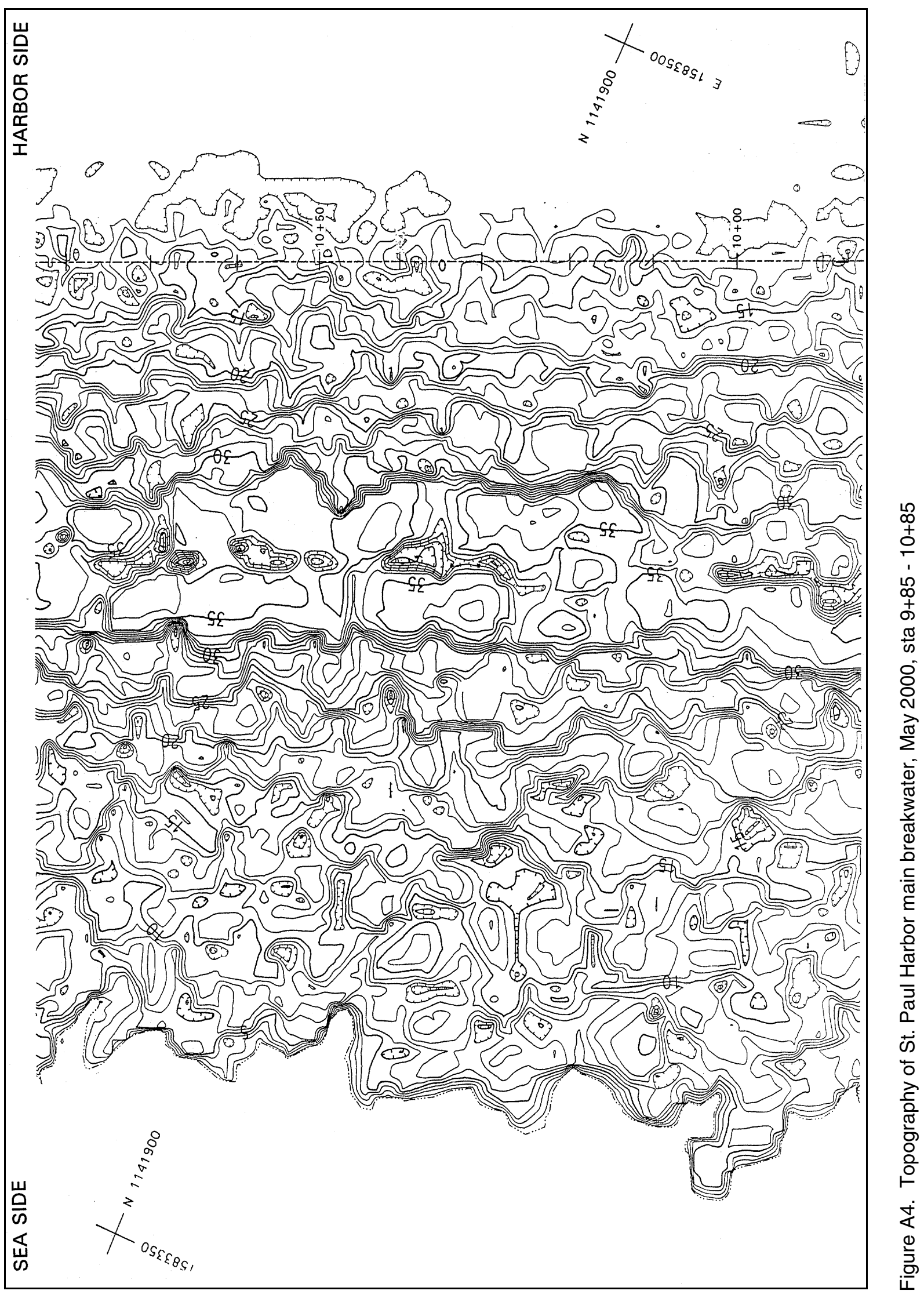




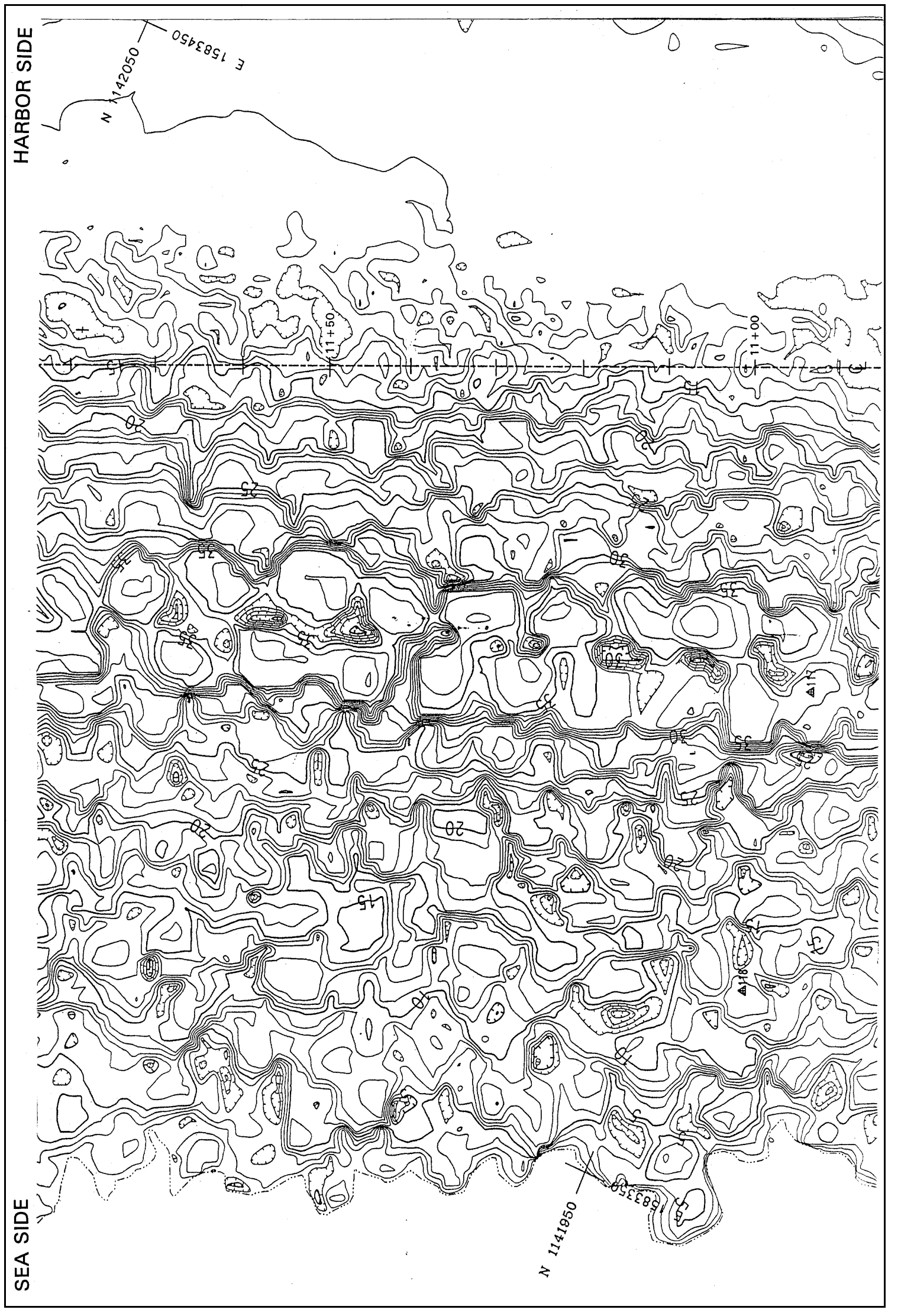

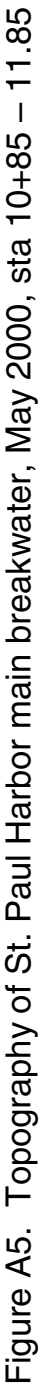




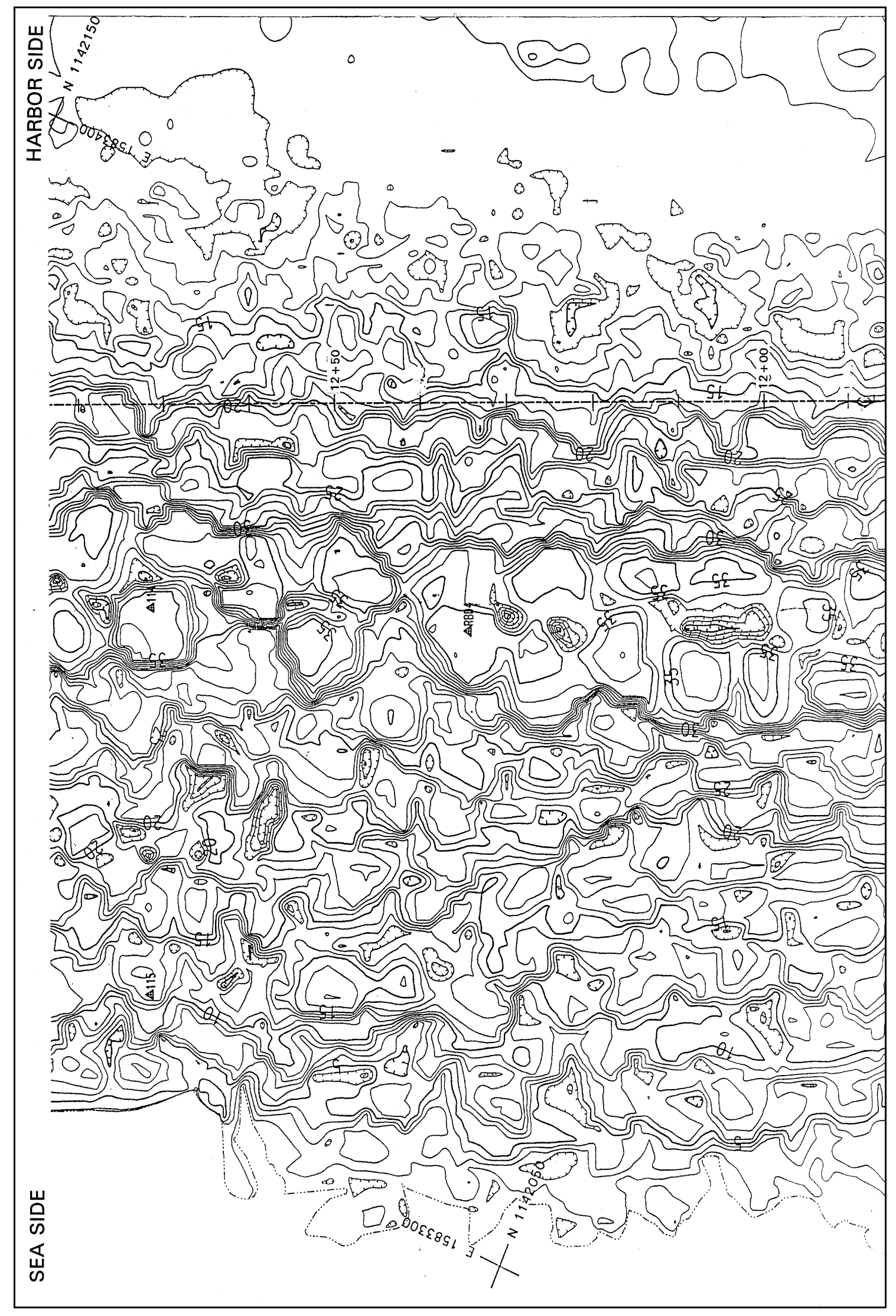

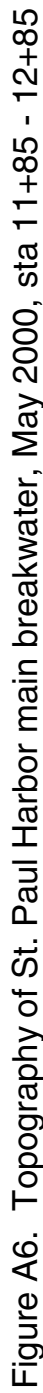




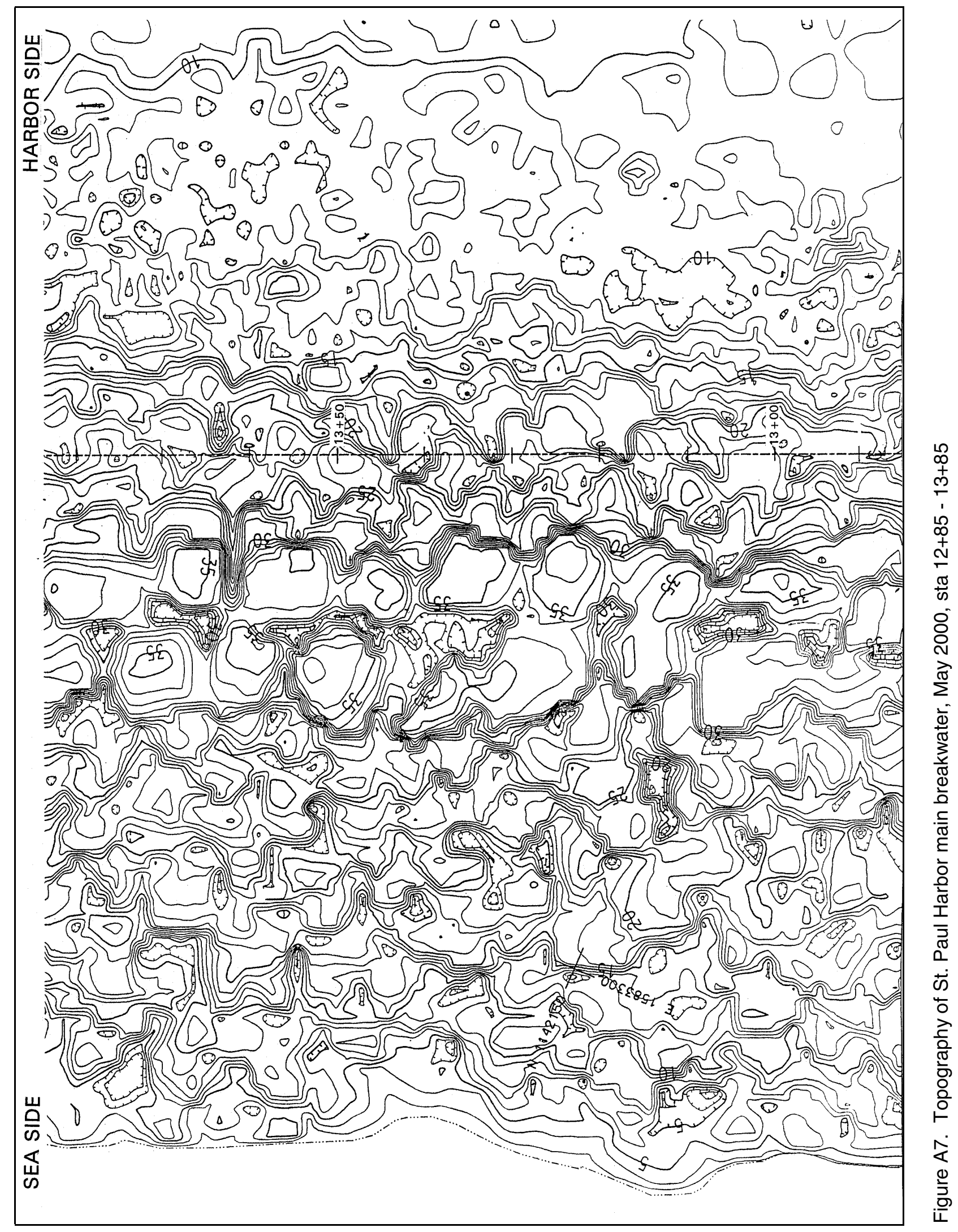




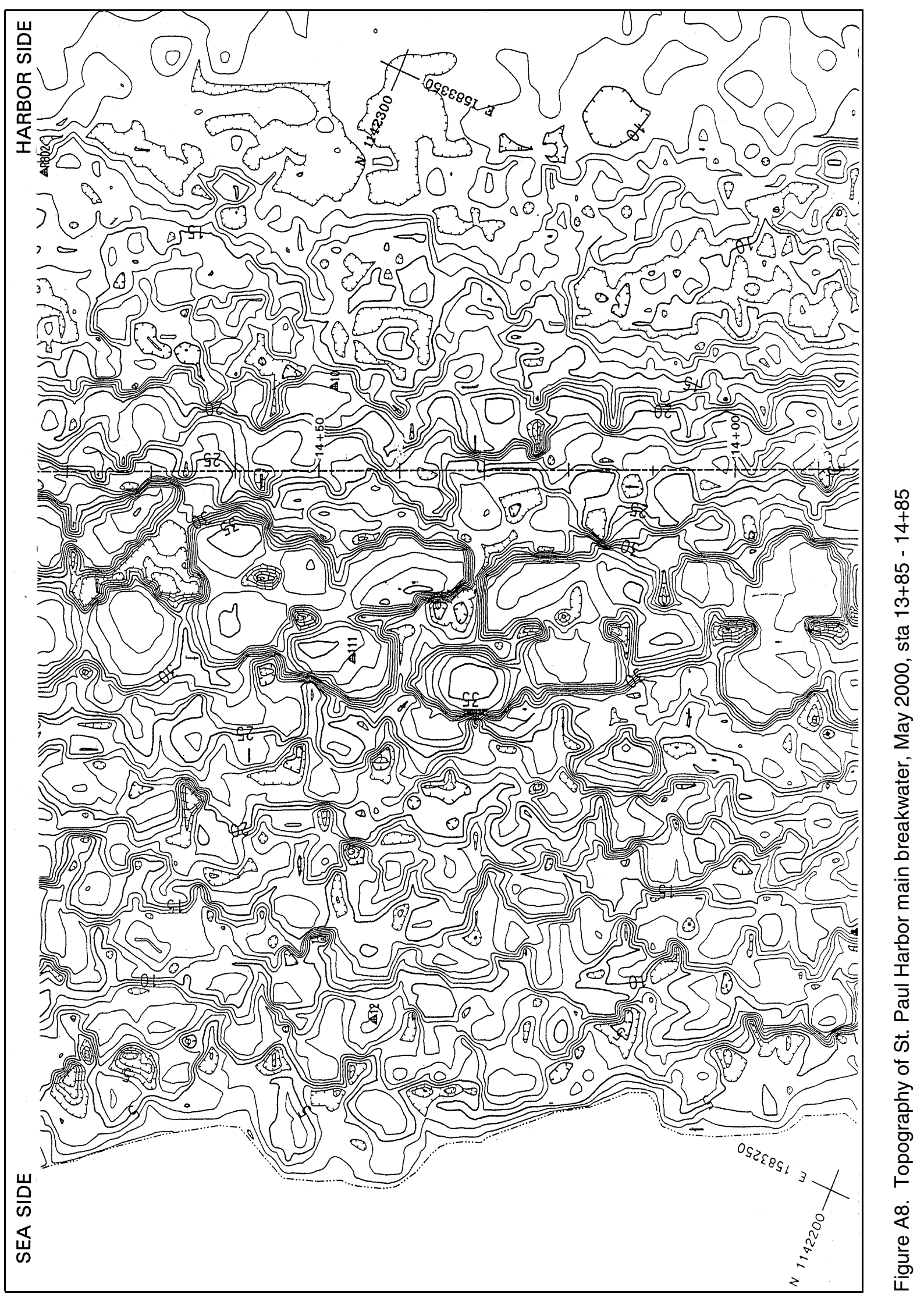




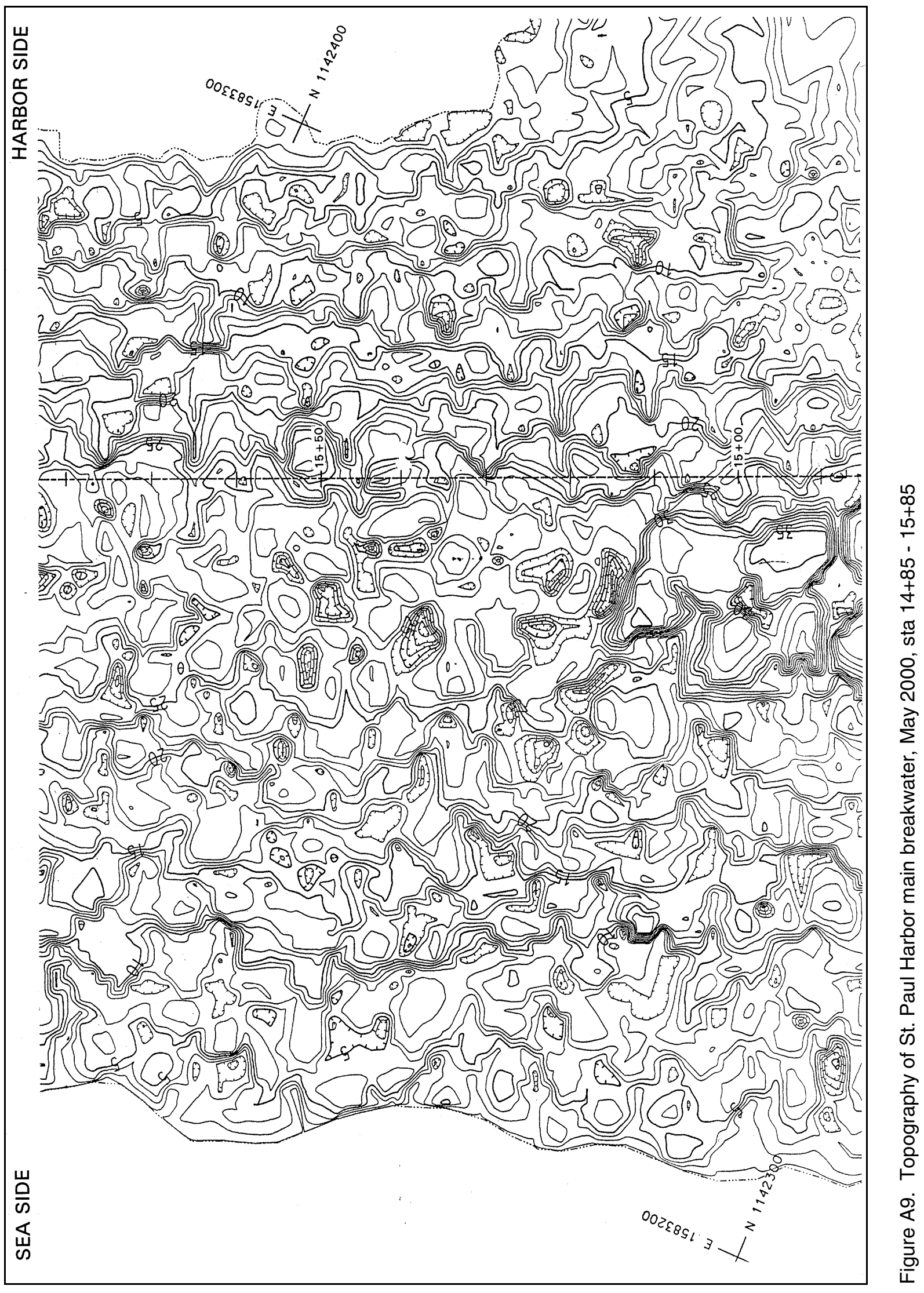




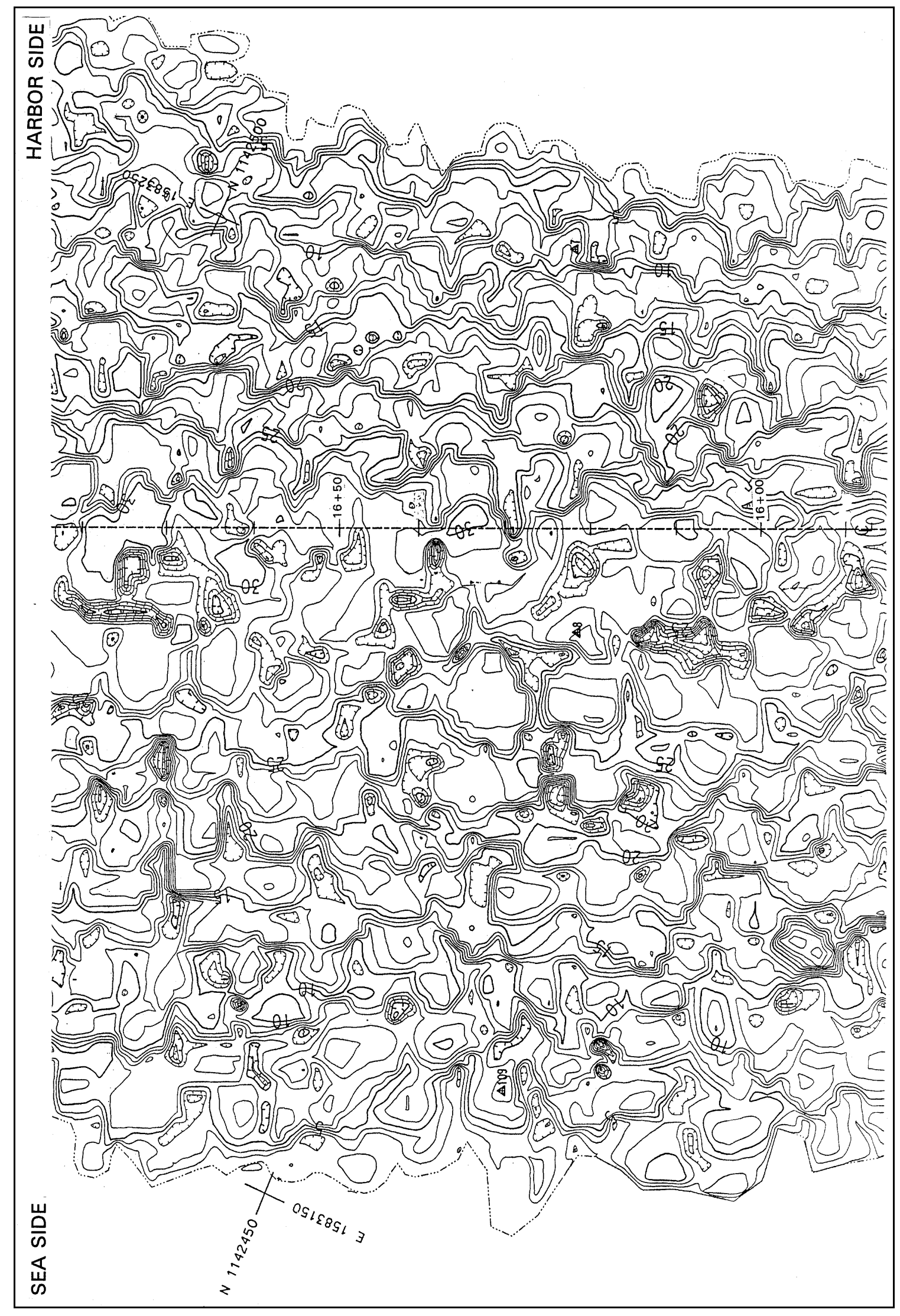

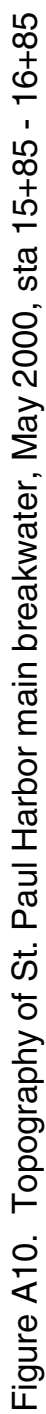




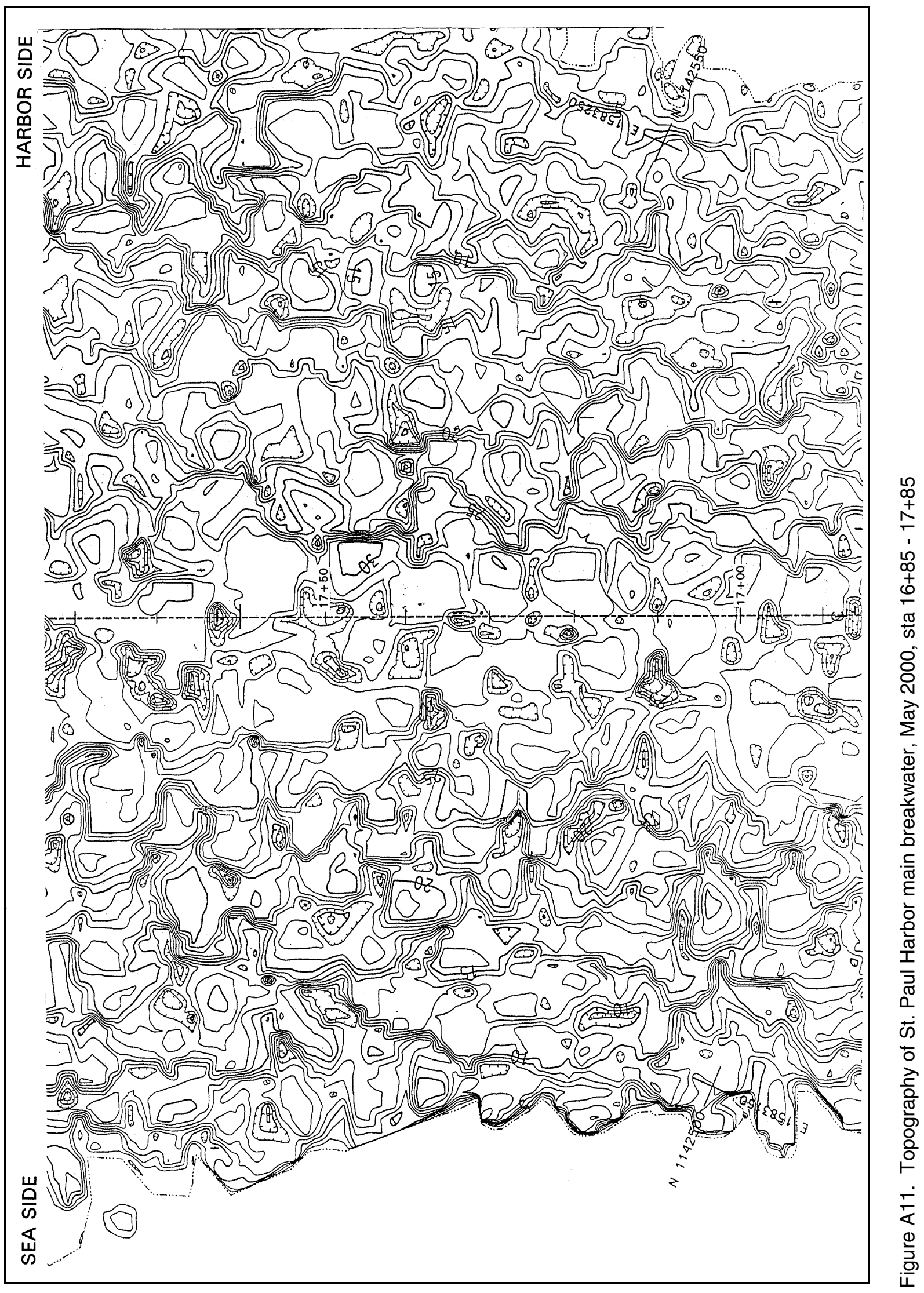




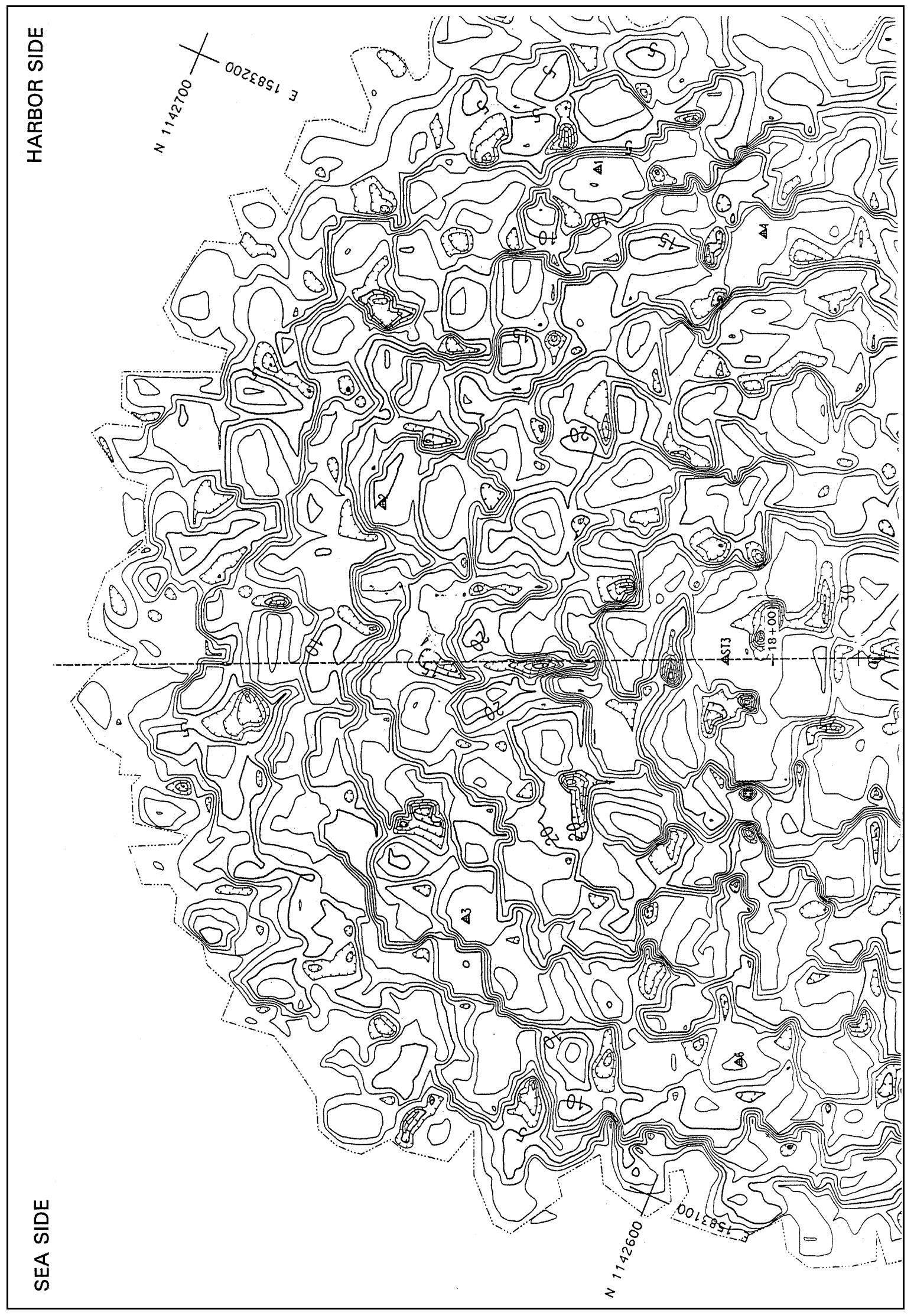

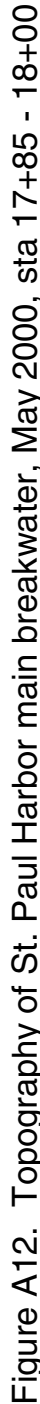




\section{Appendix B Breakwater Cross Sections, 1994, 1996, and 2000}

This appendix presents cross sections of the St. Paul Harbor breakwater extension for the 1994, 1996, and 2000 surveys. Cross sections were developed using the digital terrain model (DTM) grid as stated in the main text of this report. They were obtained at $30.5-\mathrm{m}(100-\mathrm{ft})$ intervals along the trunk of the breakwater. Elevations shown are in feet referred to mean lower low water (mllw) datum. Distances from the baseline also are shown in feet. To convert feet to meters, multiple by 0.3048 . Negative distances are measured relative to the sea side of the baseline and positive distances are measured relative to the harbor side of the baseline. 


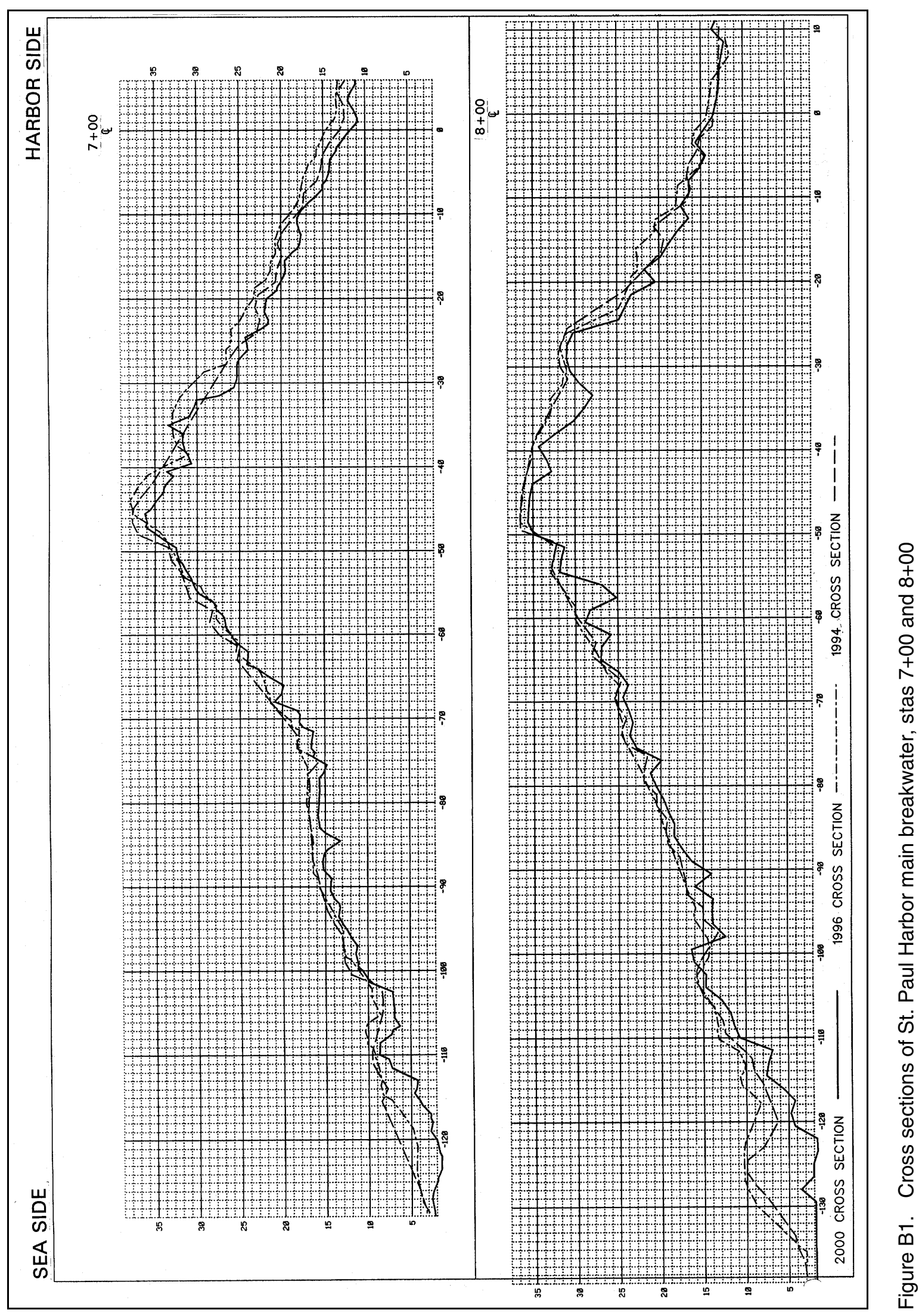




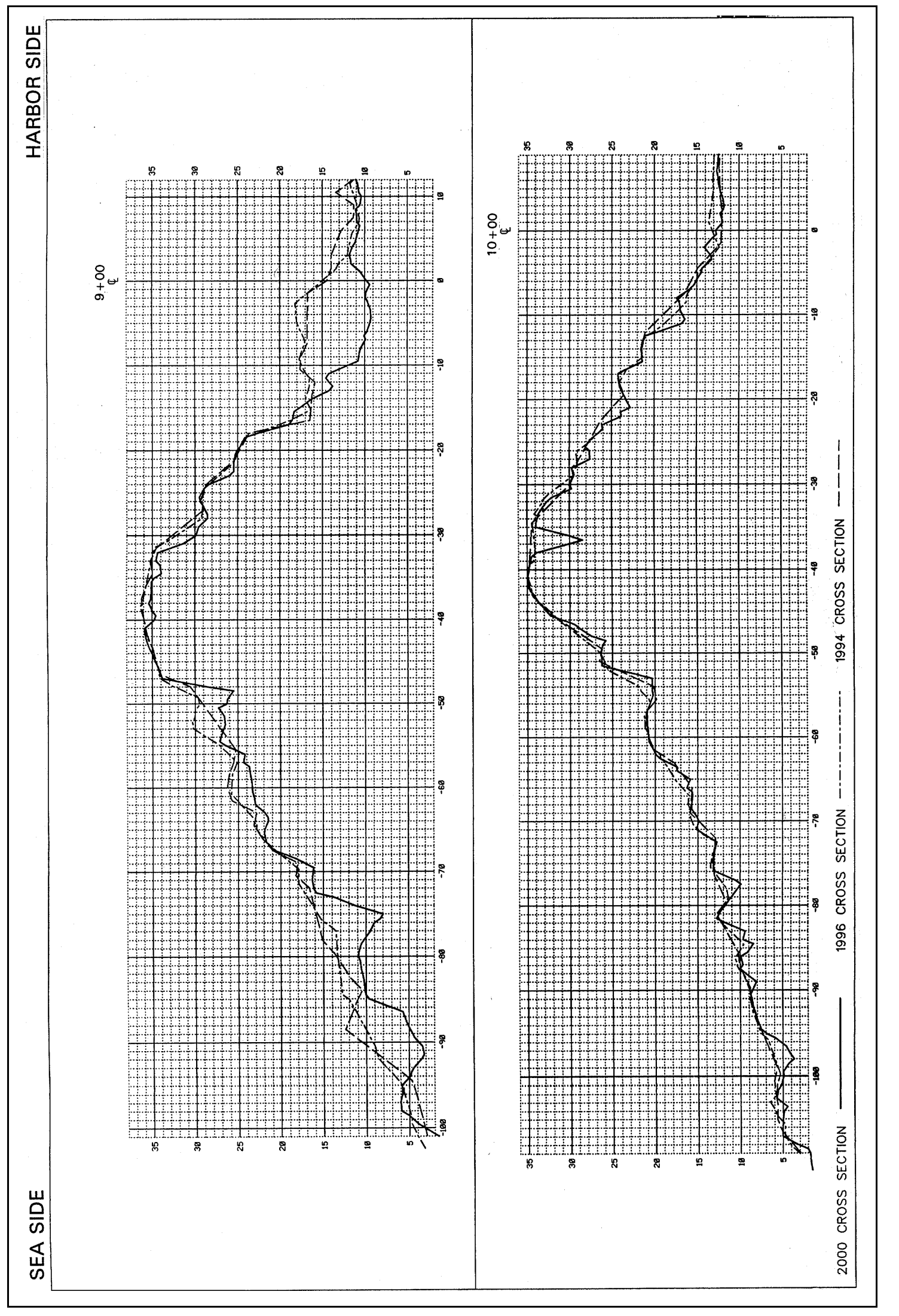

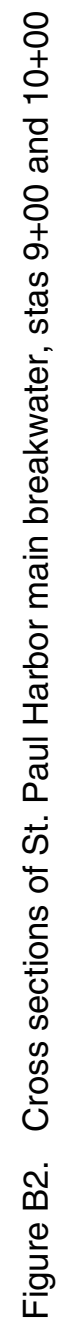




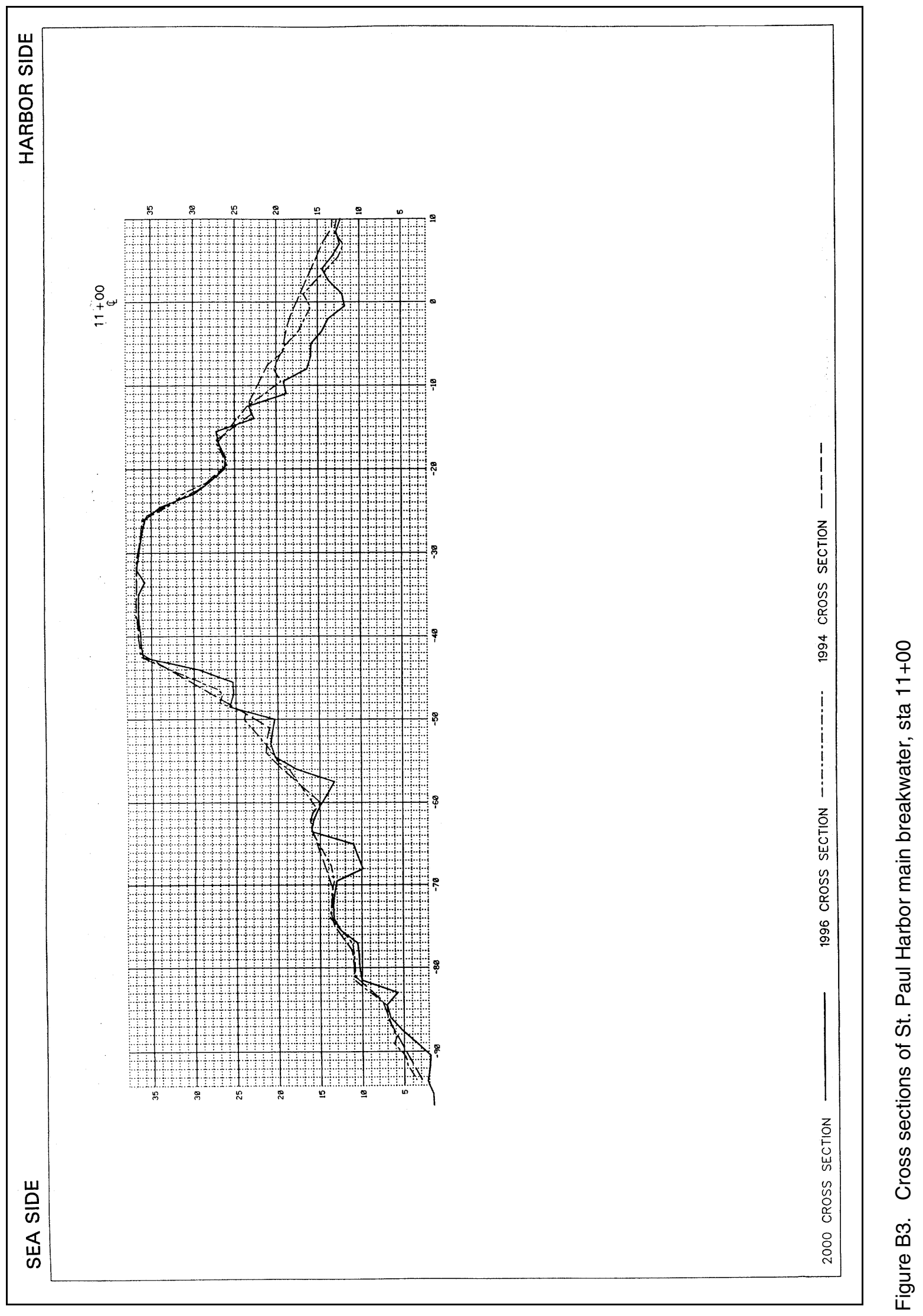




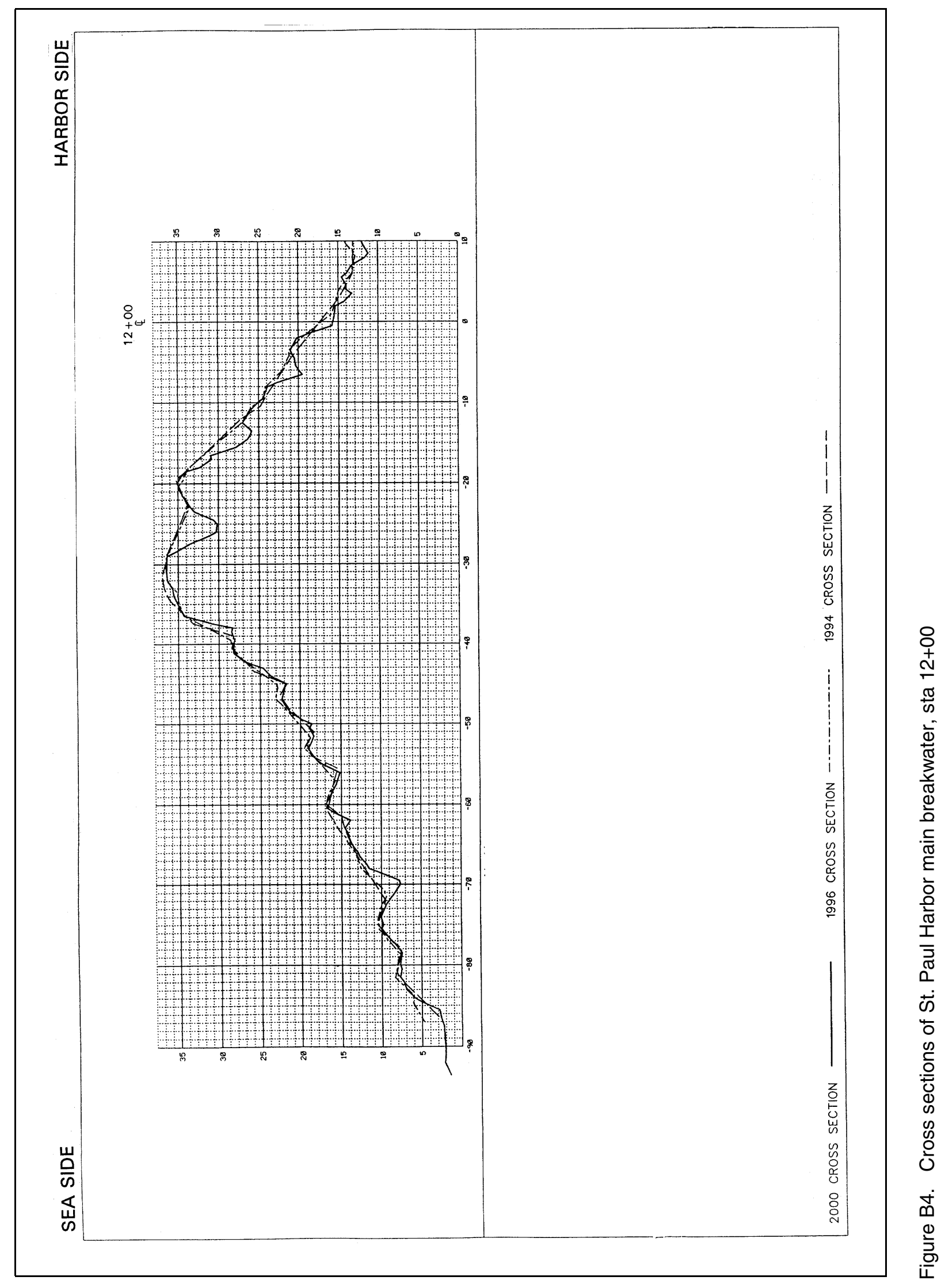




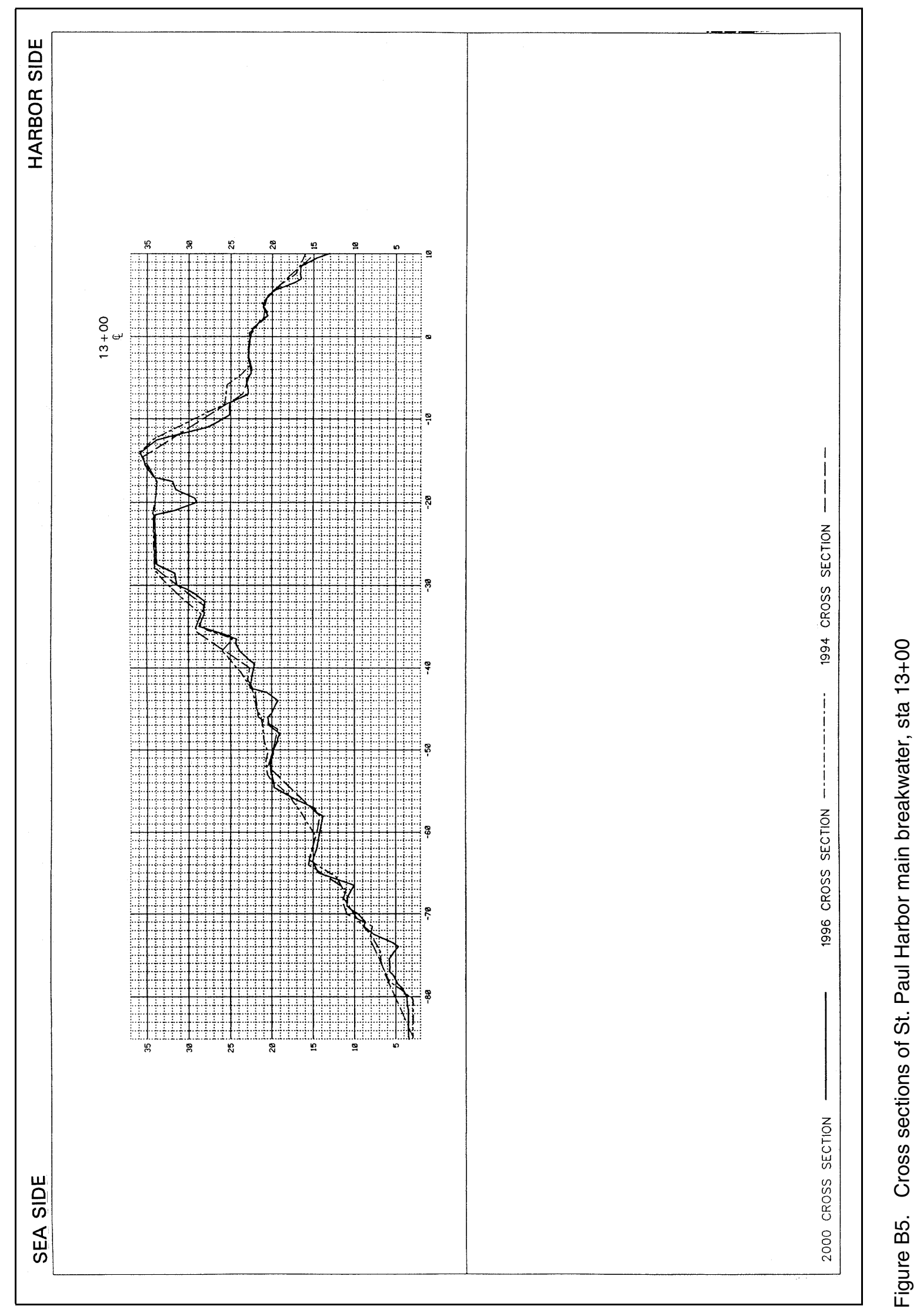




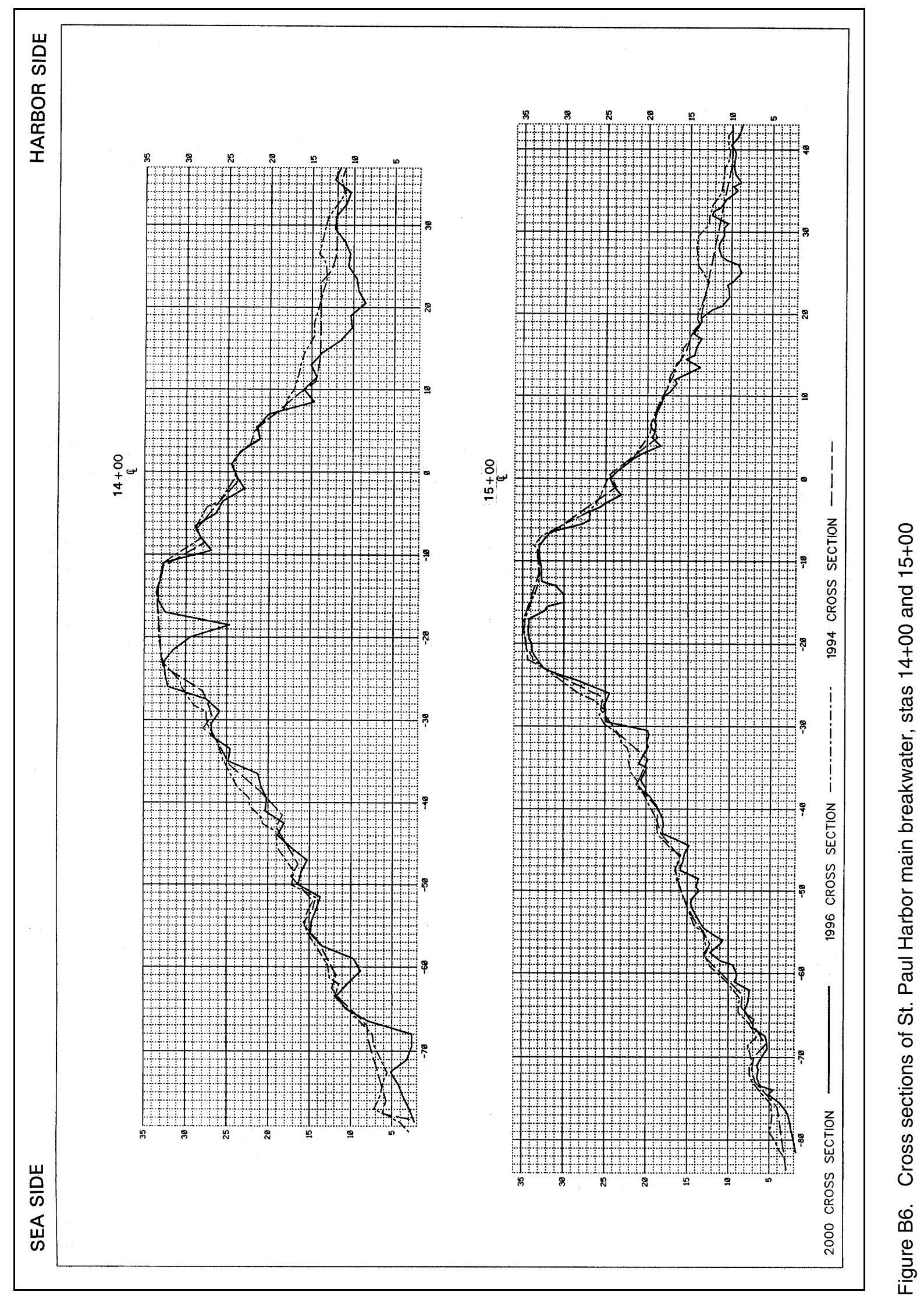




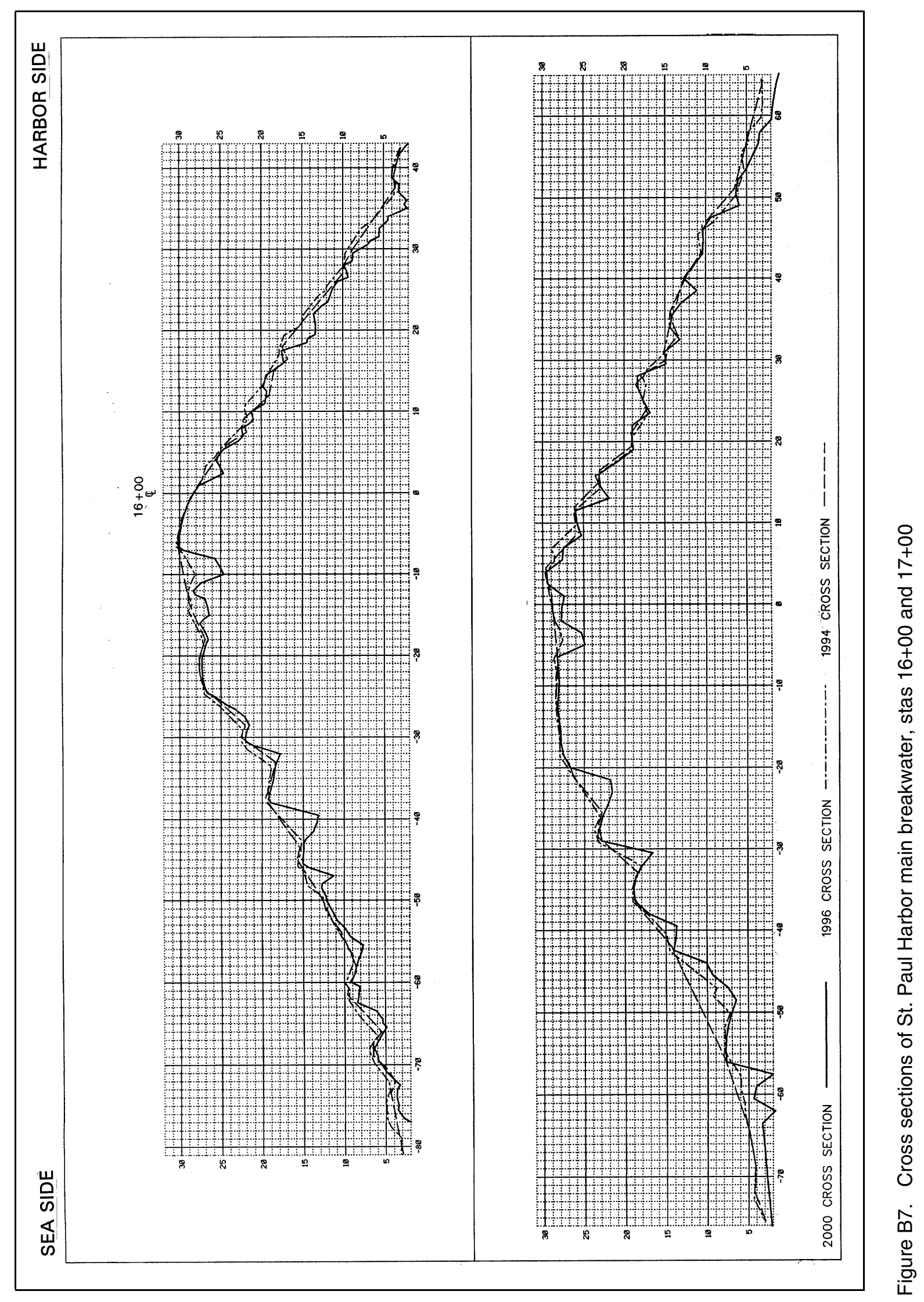




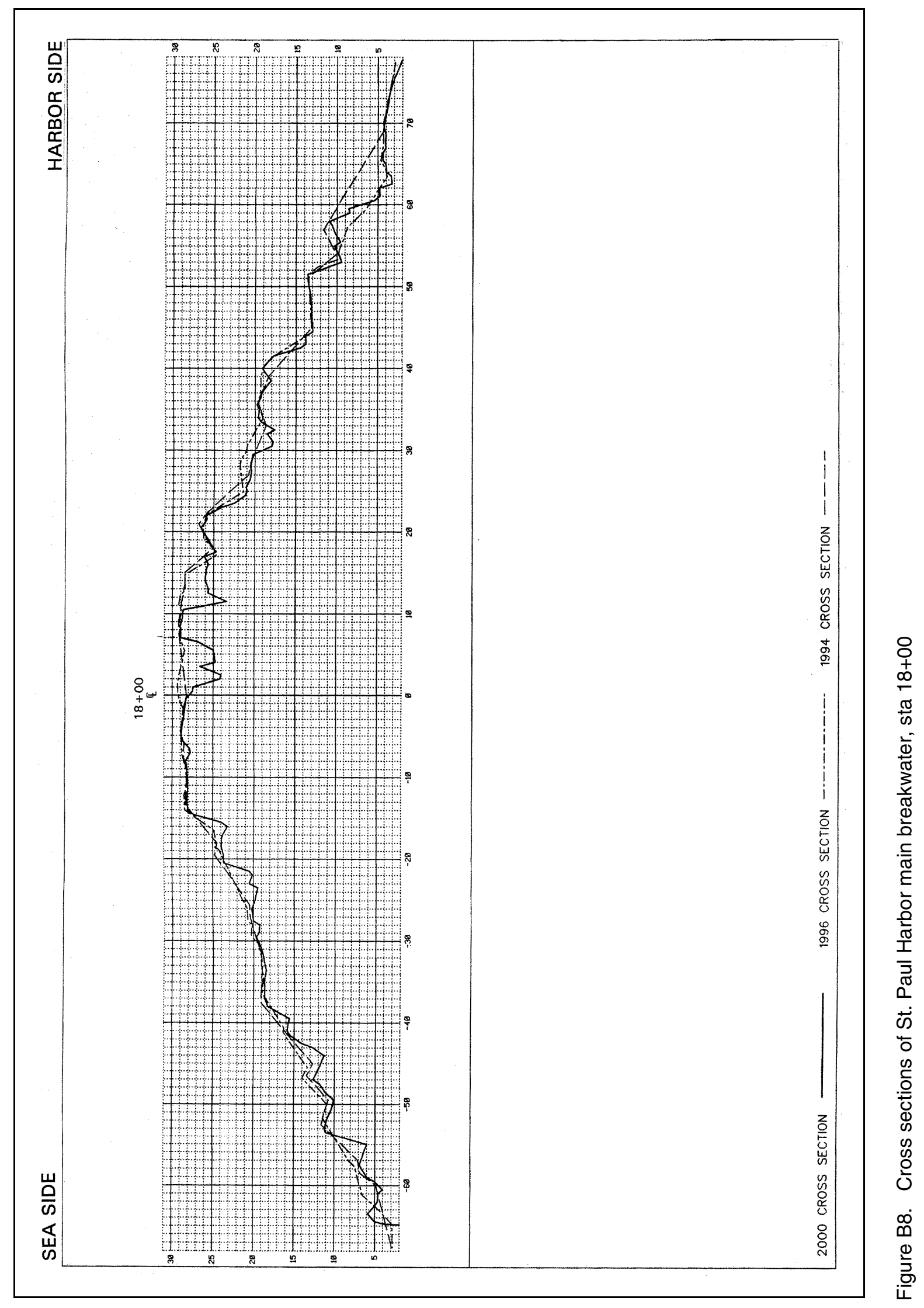

Appendix B Breakwater Cross Sections, 1994, 1996, and 2000 


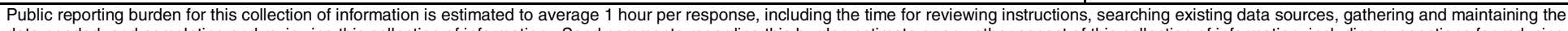

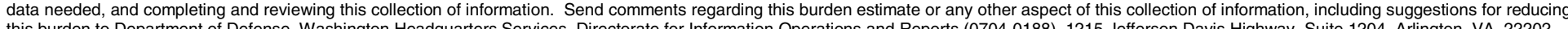

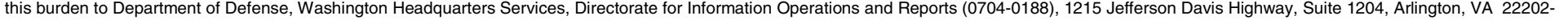

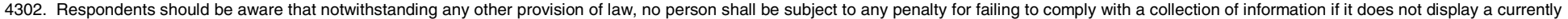
valid OMB control number. PLEASE DO NOT RETURN YOUR FORM TO THE ABOVE ADDRESS.

\begin{tabular}{l|l|l} 
1. REPORT DATE (DD-MM- $Y Y Y Y)$ & 2. REPORT TYPE & 3. DATES COVERED (FrOm - To)
\end{tabular}

February 2001

4. TITLE AND SUBTITLE

Final Report

Periodic Inspection of St. Paul Harbor Breakwater, Alaska

5a. CONTRACT NUMBER

b. GRANT NUMBER

5c. PROGRAM ELEMENT NUMBER

6. AUTHOR(S)

Robert R. Bottin, Jr., Alan C. Jeffries

5d. PROJECT NUMBER

5e. TASK NUMBER

5f. WORK UNIT NUMBER

8. PERFORMING ORGANIZATION REPORT NUMBER

U.S. Army Engineer Research and Development Center

Coastal and Hydraulics Laboratory

ERDC/CHL TR-01-2

3909 Halls Ferry Road

Vicksburg, MS 39180-6199;

U.S. Army Engineer District, Alaska

P.O. Box 898

Anchorage, AK 99506-0898

9. SPONSORING / MONITORING AGENCY NAME(S) AND ADDRESS(ES)

10. SPONSOR/MONITOR'S ACRONYM(S)

U.S. Army Corps of Engineers

Washington, DC 20314-1000

11. SPONSOR/MONITOR'S REPORT NUMBER(S)

\section{DISTRIBUTION / AVAILABILITY STATEMENT}

Approved for public release; distribution is unlimited.

\section{SUPPLEMENTARY NOTES}

\section{ABSTRACT}

Under the Periodic Inspections Work Unit of the Monitoring Completed Navigation Projects Program, precise position data have been re-established for the above-water armor stone on the St. Paul Harbor breakwater extension and compared with data obtained previously. The positions of the armor stone layer over the 320-m (1,050-ft) length of the breakwater extension was defined through limited ground surveys, aerial photography, and photogrammetric analysis. Contour maps of the breakwater as well as cross sections of the structure were developed. In addition, a database of broken armor stones was updated. Results of the monitoring indicated that essentially no change in the overall breakwater crest elevation and shape of the structure had occurred since the last inspection of 1996. There were localized areas of the breakwater, however, where void has occurred (likely due to displacement of armor stones). The rate of stone breakage also appears to have declined since the last survey. The site will be revisited periodically in the future and the long-term structural response of the breakwater to its environment will continue to be tracked. The periodic data sets will be used to improve knowledge in design, construction, and maintenance of the existing structure as well as proposed future coastal projects.

\begin{tabular}{|c|c|c|c|c|c|c|}
\hline $\begin{array}{l}\text { 15. SUBJECT TERMS } \\
\text { Aerial photography } \\
\text { Armor stone }\end{array}$ & $\begin{array}{l}\text { Breakwa } \\
\text { Orthoph }\end{array}$ & hy & $\begin{array}{l}\text { Periodic } \\
\text { Photogl }\end{array}$ & $\begin{array}{l}\text { nspections } \\
\text { nmetry }\end{array}$ & $\begin{array}{l}\text { Remote sensing } \\
\text { St. Paul Harbor, A }\end{array}$ & $\begin{array}{l}\text { Stereo pairs } \\
\text { Stone deterioration }\end{array}$ \\
\hline 16. SECURITY CLASS & FICATION OF: & & & 17. LIMITATION & 18. NUMBER & 19a. NAME OF RESPONSIBLE PERSON \\
\hline $\begin{array}{l}\text { a. REPORT } \\
\text { UNCLASSIFIED }\end{array}$ & b. ABSTRACT & $\begin{array}{l}\text { c. T } \\
\text { UN }\end{array}$ & $\begin{array}{l}\text { GE } \\
\text { SIFIED }\end{array}$ & & 65 & $\begin{array}{l}\text { 19b. TELEPHONE NUMBER (include area } \\
\text { code) }\end{array}$ \\
\hline
\end{tabular}

